Prepared in cooperation with the City of Indianapolis, the Indianapolis Museum of Art, the Indiana Department of Homeland Security, and the Indiana Department of Natural Resources, Division of Water

\title{
Observed and Forecast Flood-Inundation Mapping Application: A Pilot Study of an Eleven-Mile Reach of the White River, Indianapolis, Indiana
}

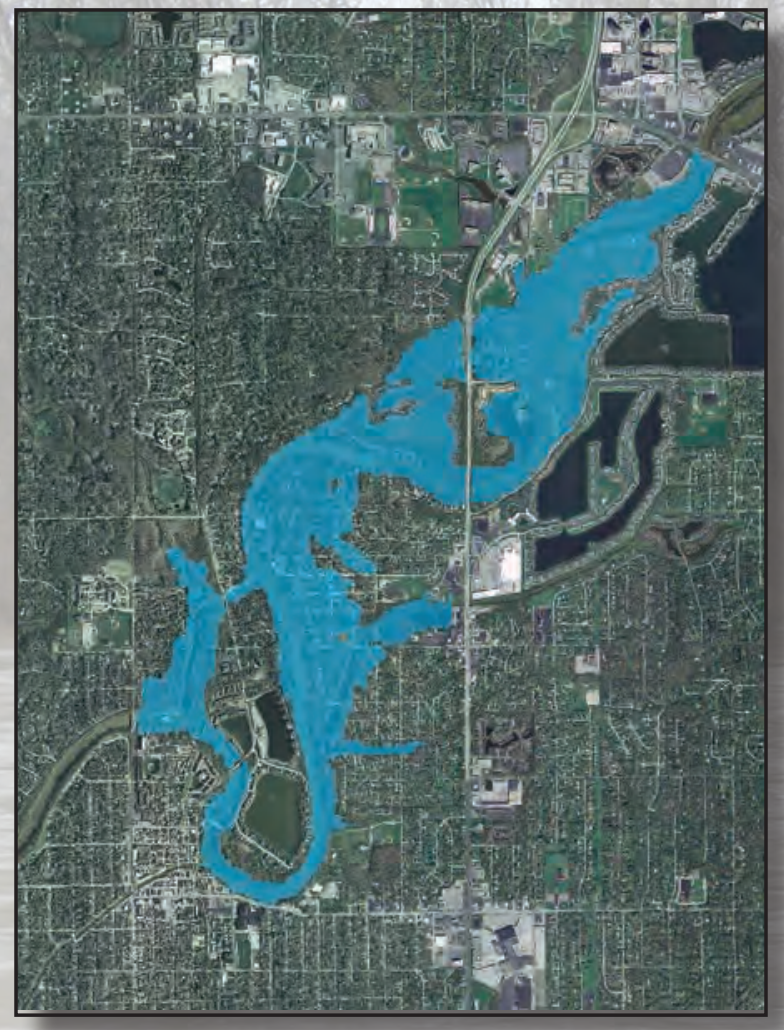

Scientific Investigations Report 2011-5138 
Cover. U.S. Geological Survey personnel collecting bathymetric data in White River at the Indianapolis Museum of Art, Indiana, February 7, 2008 (photograph by David C. Lampe, U.S. Geological Survey), and part of an inundation map showing approximate flood extents for White River near Nora, Indiana (entire map is in appendix 2 of the report). 


\section{Observed and Forecast Flood-Inundation Mapping Application: A Pilot Study of an Eleven-Mile Reach of the White River, Indianapolis, Indiana}

By Moon H. Kim, Scott E. Morlock, Leslie D. Arihood, and James L. Kiesler

Prepared in cooperation with the City of Indianapolis, the Indianapolis Museum of Art, the Indiana Department of Homeland Security, and the Indiana Department of Natural Resources, Division of Water

Scientific Investigations Report 2011-5138 


\title{
U.S. Department of the Interior \\ KEN SALAZAR, Secretary
}

\author{
U.S. Geological Survey \\ Marcia K. McNutt, Director
}

U.S. Geological Survey, Reston, Virginia: 2011

For more information on the USGS - the Federal source for science about the Earth, its natural and living resources, natural hazards, and the environment, visit http://www.usgs.gov or call 1-888-ASK-USGS.

For an overview of USGS information products, including maps, imagery, and publications, visit http://www.usgs.gov/pubprod

To order this and other USGS information products, visit http://store.usgs.gov

Any use of trade, product, or firm names is for descriptive purposes only and does not imply endorsement by the U.S. Government.

Although this report is in the public domain, permission must be secured from the individual copyright owners to reproduce any copyrighted materials contained within this report.

Suggested citation:

Kim, M.H., Morlock, S.E., Arihood, L.D., and Kiesler, J.L., 2011, Observed and forecast flood-inundation mapping application-A pilot study of an eleven-mile reach of the White River, Indianapolis, Indiana: U.S. Geological Survey Scientific Investigations Report 2011-5138, 63 p., 3 app. 


\section{Acknowledgments}

The authors thank the many agencies and individuals that have contributed invaluable information to this report. The following individuals are acknowledged for their extensive technical support, expertise, and advice during all phases of this study: John Buechler, Neil Devadasan, and Kevin Mickey of the Polis Center; Yu (Marie) Ma and Marlon Pierce of the Indiana University Community Grids Lab; and Kris Lander and Victor Hom of the National Weather Service. The authors also acknowledge the support and contributions of Mark Zelonis and David Hunt of the Indianapolis Museum of Art; Al Shipe and Sally Pavlow of the National Weather Service; Jan Crider, Manuela Johnson, and Mary Moran of the Indiana Department of Homeland Security; and personnel from the Indiana Department of Natural Resources, Division of Water, the Indiana Silver Jackets Hazard Mitigation Taskforce, and the City of Indianapolis.

The authors acknowledge Emily Pysh of the Rhode Island Emergency Management Agency and Kathleen K. Fowler of the U.S. Geological Survey for their thorough and timely review of technical aspects of this study. Michael Eberle of the U.S. Geological Survey is acknowledged for his meticulous editorial review of the report. The many hydrologists and hydrologic technicians from the U.S. Geological Survey Indiana Water Science Center who assisted with field and office aspects of the project also are acknowledged. 


\section{Contents}

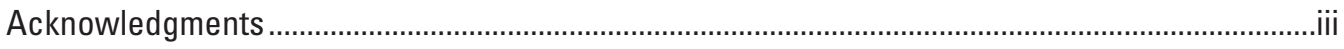

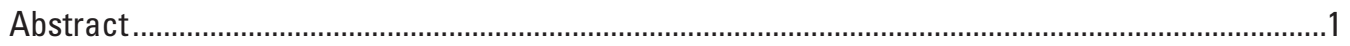

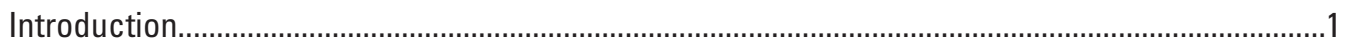

Description of Study Area .....................................................................................................................

Development of a Static Flood-Inundation Map Library ....................................................................4

Selection of Hydraulic Model ......................................................................................................

Data Requirements for Model Construction and Calibration .....................................................6

Model Calibration and Performance ........................................................................................

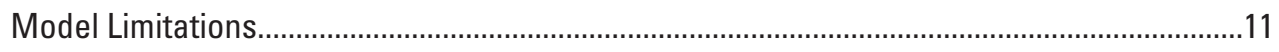

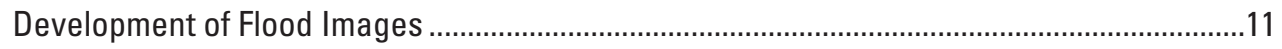

Dissemination of Flood-Inundation Map Libraries .................................................................11

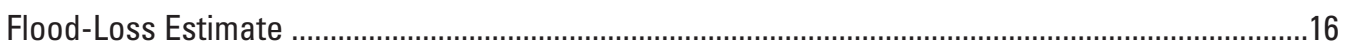

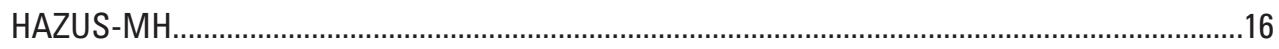

Pilot Project HAZUS-MH Level 2 Analysis.............................................................................17

Development of a Dynamic Flood Mapping Application .....................................................................17

Dynamic Application Requirements .....................................................................................17

Service-Oriented Architecture ........................................................................................... 18

Dynamic Application Integration and Testing ..........................................................................18

Dynamic Application Limitations and Future Needs................................................................22

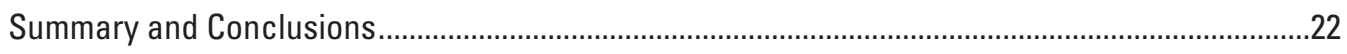

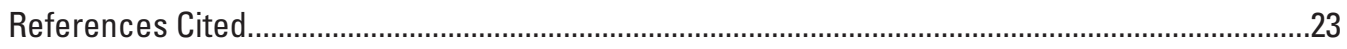

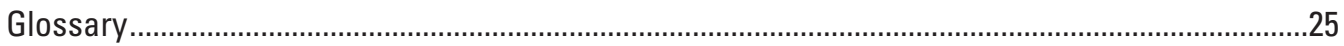

Appendix 1. Static inundation maps for White River at Indianapolis Museum of Art, Indiana (Virginia B. Fairbanks Art and Nature Park) ...............................................27

Appendix 2. Static inundation maps for White River near Nora, Indiana ...................................41

Appendix 3. Examples of metadata for Geographic Information System (GIS) layers used to create maps in appendix 2 . 


\section{Figures}

1. Map showing location of study area, White River, Indianapolis, Indiana..........................3

2. Map showing locations of U.S. Geological Survey streamgages, National Weather Service river observation and forecast points, and calibration points for water-surface elevation, White River, Indianapolis, Indiana .

3. Map showing distribution of model nodes at southern end of modeled area, White River, Indianapolis, Indiana . .8

4. Map showing area where the channel bottom was lowered by 10 feet in the surface-water model, White River, Indianapolis, Indiana .9

5. Graph showing residuals of simulated and measured water-surface elevation along the White River, Indianapolis, Indiana

6. Example screenshot from a local map server showing a flood image from the White River pilot study, Indianapolis, Indiana.

7. Example screenshot (showing inundation along the Blanchard River, Findlay, Ohio) from the National Weather Service-Advanced Hydrologic Prediction Service Web site.

8. Example screenshot from the U.S. Geological Survey Flood Inundation Mapping Initiative Web site.

9. Example screenshot from the dynamic flood-mapping application ..............................20

10. Simplified flowchart for the dynamic flood-mapping application 


\section{Conversion Factors and Datums}

\begin{tabular}{|c|c|c|}
\hline Multiply & By & To obtain \\
\hline \multicolumn{3}{|c|}{ Length } \\
\hline foot (ft) & 0.3048 & meter $(\mathrm{m})$ \\
\hline meter (m) & 3.281 & foot $(\mathrm{ft})$ \\
\hline mile (mi) & 1.609 & kilometer $(\mathrm{km})$ \\
\hline \multicolumn{3}{|c|}{ Area } \\
\hline acre & 4,047 & square meter $\left(\mathrm{m}^{2}\right)$ \\
\hline acre & 0.4047 & hectare (ha) \\
\hline acre & 0.004047 & square kilometer $\left(\mathrm{km}^{2}\right)$ \\
\hline square mile $\left(\mathrm{mi}^{2}\right)$ & 259.0 & hectare (ha) \\
\hline square mile $\left(\mathrm{mi}^{2}\right)$ & 2.590 & square kilometer $\left(\mathrm{km}^{2}\right)$ \\
\hline \multicolumn{3}{|c|}{ Flow rate } \\
\hline foot per second (ft/s) & 0.3048 & meter per second (m/s) \\
\hline cubic foot per second $\left(\mathrm{ft}^{3} / \mathrm{s}\right)$ & 0.02832 & cubic meter per second $\left(\mathrm{m}^{3} / \mathrm{s}\right)$ \\
\hline \multicolumn{3}{|c|}{ Kinematic viscosity } \\
\hline meter squared per second $\left(\mathrm{m}^{2} / \mathrm{s}\right)$ & 10.76 & foot squared per second $\left(\mathrm{ft}^{2} / \mathrm{s}\right)$ \\
\hline
\end{tabular}

Vertical coordinate information is referenced to the North American Vertical Datum of 1988 (NAVD 88) or the National Geodetic Vertical Datum of 1929 (NGVD 29).

Horizontal coordinate information is referenced to the North American Datum of 1983 (NAD 83).

Elevation, as used in this report, refers to distance above the vertical datum. 


\section{Abbreviations and Acronyms}

$\begin{array}{ll}\text { AHPS } & \text { Advanced Hydrologic Prediction Service } \\ \text { CAMA } & \text { Computer Assisted Mass Appraisal } \\ \text { CGNS } & \text { Computational fluid dynamics General Notation System } \\ \text { DEM } & \text { Digital Elevation Model } \\ \text { FEMA } & \text { Federal Emergency Management Agency } \\ \text { FIA } & \text { Federal Insurance Agency } \\ \text { GIS } & \text { Geographic Information System } \\ \text { GUI } & \text { Graphical User Interface } \\ \text { IDHS } & \text { Indiana Department of Homeland Security } \\ \text { IDNR } & \text { Indiana Department of Natural Resources } \\ \text { IMA } & \text { Indianapolis Museum of Art } \\ \text { IMAGIS } & \text { Indianapolis Mapping and Geographic Infrastructure System } \\ \text { ISDP } & \text { Indiana Spatial Data Portal } \\ \text { KML } & \text { Keyhole Markup Language } \\ \text { MD_SWMS } & \text { Multi-Dimensional Surface-Water Modeling System } \\ \text { NED } & \text { National Elevation Dataset } \\ \text { NWS } & \text { National Weather Service } \\ \text { PDF } & \text { Portable Document Format } \\ \text { OC } & \text { Quality Control } \\ \text { SOA } & \text { Service-Oriented Architecture } \\ \text { USGS } & \text { U.S. Geological Survey } \\ \text { XML } & \text { Extensible Markup Language }\end{array}$





\title{
Observed and Forecast Flood-Inundation Mapping Application: A Pilot Study of an Eleven-Mile Reach of the White River, Indianapolis, Indiana
}

\author{
By Moon H. Kim, Scott E. Morlock, Leslie D. Arihood, and James L. Kiesler
}

\section{Abstract}

Near-real-time and forecast flood-inundation mapping products resulted from a pilot study for an 11-mile reach of the White River in Indianapolis. The study was done by the U.S. Geological Survey (USGS), Indiana Silver Jackets hazard mitigation taskforce members, the National Weather Service (NWS), the Polis Center, and Indiana University, in cooperation with the City of Indianapolis, the Indianapolis Museum of Art, the Indiana Department of Homeland Security, and the Indiana Department of Natural Resources, Division of Water. The pilot project showed that it is technically feasible to create a flood-inundation map library by means of a two-dimensional hydraulic model, use a map from the library to quickly complete a moderately detailed local flood-loss estimate, and automatically run the hydraulic model during a flood event to provide the maps and flood-damage information through a Web graphical user interface.

A library of static digital flood-inundation maps was created by means of a calibrated two-dimensional hydraulic model. Estimated water-surface elevations were developed for a range of river stages referenced to a USGS streamgage and NWS flood forecast point colocated within the study reach. These maps were made available through the Internet in several formats, including geographic information system, Keyhole Markup Language, and Portable Document Format.

A flood-loss estimate was completed for part of the study reach by using one of the flood-inundation maps from the static library. The Federal Emergency Management Agency natural disaster-loss estimation program HAZUS-MH, in conjunction with local building information, was used to complete a level 2 analysis of flood-loss estimation.

A Service-Oriented Architecture-based dynamic floodinundation application was developed and was designed to start automatically during a flood, obtain near real-time and forecast data (from the colocated USGS streamgage and NWS flood forecast point within the study reach), run the twodimensional hydraulic model, and produce flood-inundation maps. The application used local building data and depthdamage curves to estimate flood losses based on the maps, and it served inundation maps and flood-loss estimates through a Web-based graphical user interface.

\section{Introduction}

Flooding causes more deaths and property damage in the United States than any other weather-related phenomenon, and three-quarters of all federally declared disaster declarations are due to flooding, at least in part (National Hydrologic Warning Council, 2006). Flood warnings and forecasts are critical for saving lives and reducing property damage before and during floods. Across the Nation, flood-related deaths have declined during the last half century, mostly because of improved floodwarning systems (U.S. Geological Survey, 2006). Flood warnings reduce property damages by improving notification and response process; for example, advance flood warning of 4 to 12 hours can reduce flood damages by 22 percent (Day, 1970).

The National Weather Service (NWS) and the U.S. Geological Survey (USGS) partner to deliver critical floodwarning information during floods. The NWS is the agency charged with issuing flood warnings and flood forecasts. The NWS provides flood forecasts at selected flood forecast points; the forecasts predict flood stages and streamflows for up to 5 days into the future. Most NWS flood forecast points are colocated with USGS streamgages. Streamgages record and transmit river stage and streamflow data that are critical to the accuracy of flood forecasts. The NWS provides flood forecasts through its Advanced Hydrologic Prediction Service (AHPS), a program designed to serve a suite of graphical and numeric flood forecast products over the Internet (National Weather Service, 2008).

USGS streamgages and NWS flood forecasts provide flood information for individual geographic points. Technological advances recently have made it possible to use the flood information from those geographic points and generate flood warnings and forecasts in the form of flood-inundation maps for long reaches of streams. These technologies are based upon USGS streamgage data and NWS flood forecasts, Geographic Information System (GIS) digital datasets, river hydraulic models, and Internet data-delivery systems. Floodinundation maps that are linked to USGS streamgage data and NWS flood forecasts allow officials to make operational and public-safety decisions based upon potential flood extents and depths. The ability to view flood-inundation maps based 
on observed and forecast stream stages assists safety officials and the public in making informed decisions regarding the implementation of evacuation plans when floodwaters threaten a community. Forecast flood-inundation maps are a valuable planning tool for community and flood-hazard mitigation planners and flood-plain managers.

There is a need for an inundation mapping application for flood-prone communities in Indiana. Indiana was ranked fifth highest of all States in terms of median flood damage for the periods 1955-1978 and 1983-1999 (Pielke and others, 2002). Flood damages in Indiana have increased in the last several decades. There were nine flood-related Federal Disaster Declarations for Indiana in the decade of the 1990s-more than the total number of flood-related declarations for the preceding four decades (Federal Emergency Management Agency, 2009a). There were 11 flood-related declarations for the period 2000 through 2008. In 2008 alone there were five major floods in Indiana, resulting in three disaster declarations. In 2006, the Indiana Silver Jackets (http://www.nfrmp.us/state/factIndiana. c $\mathrm{fm}$ ) - a hazard mitigation taskforce composed of Federal, State, and regional agencies with an interest in mitigating loss of life and property from natural hazards - recognized the need for a flood-inundation mapping application and fostered the development of a pilot project to develop near-real-time and forecast flood-inundation mapping products for an 11-mile reach of the White River in Indianapolis. The Silver Jackets coordinated not only the process of finding funding sources but also the efforts of the various taskforce agencies. The USGS, the NWS, the Polis Center of Indiana University-Purdue University Indianapolis, and Indiana University conducted the pilot project in cooperation with the City of Indianapolis, Indianapolis Museum of Art (IMA), Indiana Department of Homeland Security (IDHS), and the Indiana Department of Natural Resources (IDNR), Division of Water. The Silver Jackets determined that the pilot project should have three main components: (1) creation of a static flood-inundation map library, (2) demonstration of the utility of project products for use in a GIS-based flood-loss estimation application, and (3) development of a dynamic, near-real-time flood-inundation mapping application. Flood-inundation data are needed by Federal, State, and local agencies to make informed decisions in meeting mission requirements related to flood hazard mitigation, planning, and response. The pilot project components were designed to provide the Silver Jackets member agencies and cooperating agencies tools to meet those mission requirements. Specific examples include the following:

- The City of Indianapolis needed flood-inundation maps for flood-response actions such as evacuations, closure of levee and culvert flood gates, and distribution of assets such as workforce and sandbags.

- IMA was developing a 100-acre art and nature park (fig. 1) in the flood plain of the White River within the project reach and needed near-real-time and forecast flood-inundation maps for operational decisions, including the closing of park visitor facilities and paths.
- IDHS needed the static flood-inundation map library for mitigation activities such as the development of and maintenance of State, regional, and local multihazard mitigation plans used for determining benefit/ cost ratios related to flood-plain management projects. The near-real-time and forecast flood-inundation maps were needed for response activities such as combining flood-inundation maps with flood-loss estimation tools to compute flood damages during and/or immediately after a flood that would be in place for future events.

The components were designed such that the pilot project could be done in three phases:

1. Creation of a static flood-inundation map library.The library would be accessible in a Web-viewable and GIS-downloadable format. The library was to consist of a series of flood surfaces at increasing river stages above an established datum, ranging from a stage where minor flooding would occur up to a stage corresponding to major flood. River stages that were used to create the map library were linked to a USGS streamgage and a colocated NWS flood forecast point. The flood surfaces were to be produced at predetermined stage intervals; for example, a flood surface for every 1-ft change in stage. The flood-inundation map library is being disseminated via multiple file formats and delivery methods. The principal investigator for this component was the USGS.

2. Flood-loss estimation.-A flood surface from the static flood-inundation map library would be used in HAZUS-MH, a GIS-based risk assessment and hazard mitigation planning software program developed by the Federal Emergency Management Agency (FEMA) for analyzing potential losses from floods, hurricane winds, and earthquakes. HAZUS allows importation of data. The Polis Center was principal investigator for this component.

3. Development of a dynamic flood mapping application.-An automated application, using near realtime USGS streamgage data and NWS flood forecast data, would run a hydraulic model and produce flood surfaces in a GIS format during a flood. The application would start the model at a predetermined streamflow associated with minor flooding and produce observed and forecast flood surfaces, then periodically rerun the model to incorporate updated USGS streamgage data and NWS flood forecast adjustments. Principal investigators were the USGS, NWS, Polis Center, and Indiana University.

The purpose of this report is to document methods and findings of the flood-inundation mapping pilot project. 

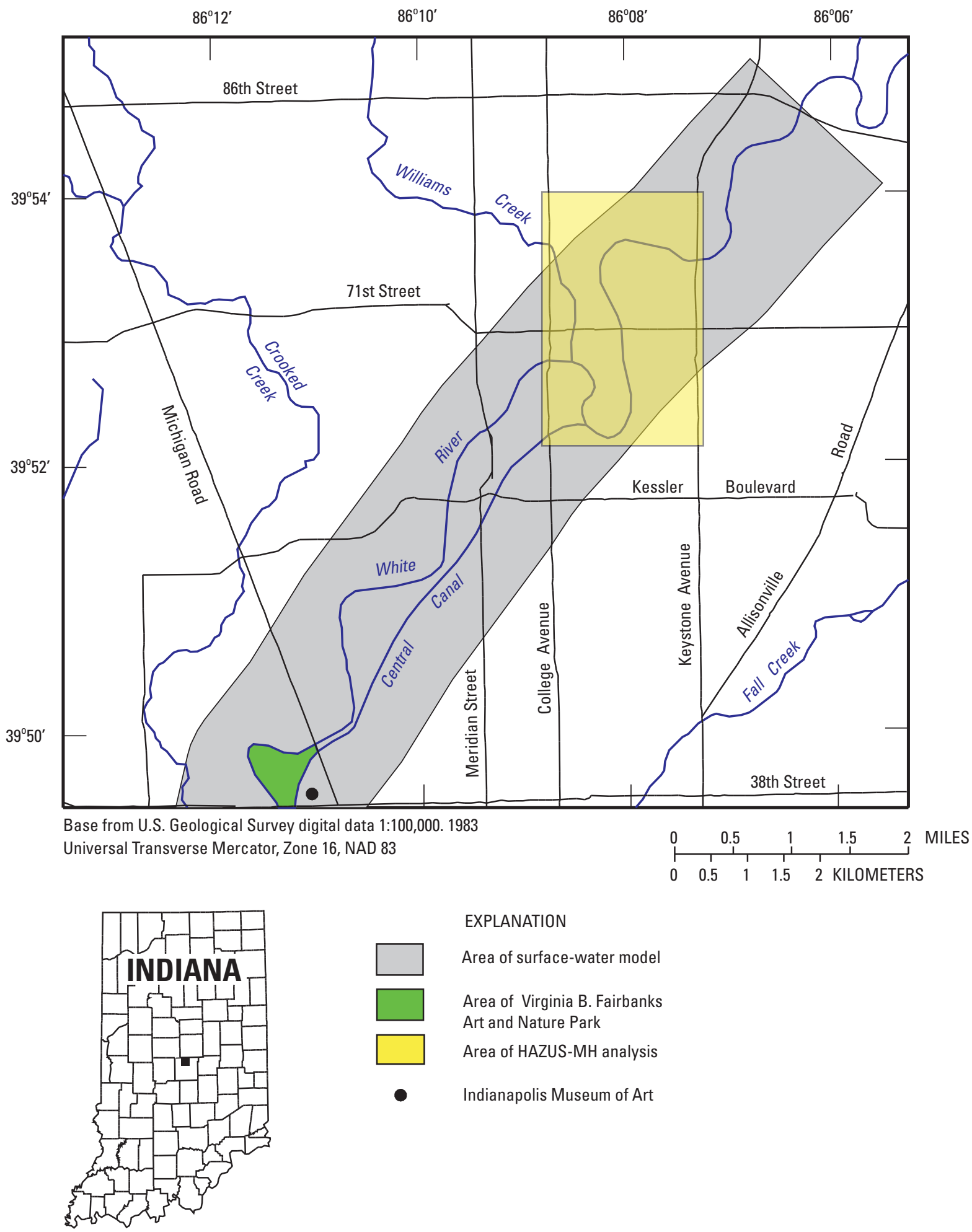

\section{EXPLANATION}

Area of surface-water model

Area of Virginia B. Fairbanks

Art and Nature Park

Area of HAZUS-MH analysis

Indianapolis Museum of Art

Figure 1. Location of study area, White River, Indianapolis, Indiana. 


\section{Description of Study Area}

The study area consisted of an 11-mile reach of the White River and contiguous flood plain within the City of Indianapolis (fig. 1). The upstream extent of the study area was the USGS streamgage 03351000 White River near Nora, IN (Nora); the period of record for the streamgage was 80 years at the time of the study. National Weather Service flood forecast point NORI3, White River at 82nd Street Bridge near Nora, was colocated with the streamgage. The downstream extent of the study area was the downstream property limit of the IMA Virginia B. Fairbanks Art and Nature Park.

The total drainage area of the White River at the downstream study extent is about $1,265 \mathrm{mi}^{2}$. The average slope of the channel through the reach is about $2.5 \mathrm{ft} / \mathrm{mi}$; channel widths range from about 110 to $280 \mathrm{ft}$. The mean annual streamflow at the Nora streamgage (as of 2009) was $1,192 \mathrm{ft}^{3} / \mathrm{s}$. The historic peak streamflow was $58,500 \mathrm{ft}^{3} / \mathrm{s}$ on March 26, 1913; the magnitude of this flood was greater than the 1-percent chance flood (100-year recurrence interval flood).

Several important modeling-related features can be identified in figure 2. One low-head dam is present about halfway down the reach. Approximately $4 \mathrm{mi}$ of flood-protection levee are within the reach. In addition to the Nora streamgage, three additional USGS streamgages are in the reach: 03351201 White River at Indianapolis Museum of Art, IN; 03351071 White River below Dam at Broad Ripple, IN; and 03351060 White River at Broad Ripple, IN. There also are two NWS observation points, White River at Ravenswood (RVNI3) and White River at Rocky Ripple (RRPI3), where manual stage readings are made by an NWS observer during floods.

The study reach was selected for the following reasons: (1) Several communities along the reach have a history of recurring damage from flooding. (2) The reach is densely populated, and major flooding has the potential to cause severe and widespread damage. (3) Data needed for flood-inundation mapping application were available, including high-resolution ground-contour intervals of 1 to $2 \mathrm{ft}$ that were converted to a digital elevation model (DEM), an NWS flood forecast point, four USGS streamgages, and extensive historical high-water data. (4) The presence of low-head dams and levees presented stream hydraulic modeling challenges that would be common on other river reaches in urban communities; thus, those challenges needed to be addressed to demonstrate that this type of project could be done for other flood-prone communities.

\section{Development of a Static Flood- Inundation Map Library}

A flood-inundation map library was created for the study reach by simulating water-surface elevations and then combining these elevations with the topographic data to create two-dimensional mapped water surfaces, or flood images. The term "library" refers to the fact that a series of flood images was created for river stages ranging from the stage associated with a minor flood to a stage associated with the extreme-high expected flood. This section documents the hydraulic modeling for simulating the water-surfaces and creation of the flood images.

\section{Selection of Hydraulic Model}

Either a one-dimensional (1D) or a two-dimensional (2D) hydraulic model could have been selected to simulate watersurfaces for the study reach. In a 1D model, cross sections provide a representation of the channel geometry, elevation and distance; the model is considered to be $1 \mathrm{D}$ because the direction of flow along the channel is assumed to be perpendicular to the cross sections (U.S. Department of Transportation, 2009). Flow expansion and contraction can occur between cross sections, and flow in the vertical direction is not simulated. In general, 1D models have the advantage of simplicity and speed over 2D models; the advantage of speed is both in model setup and in the runtime of the computer simulation (U.S. Department of Transportation, 2009).

Generally, 2D models use either finite-difference or finite-element computational methods; they are considered $2 \mathrm{D}$ in the sense that they compute velocity magnitude and direction (two horizontal components) and ignore any vertical component of flow (U.S. Department of Transportation, 2009). Although $2 \mathrm{D}$ models require greater effort to develop and increased computer time to run a simulation, they are well suited for complex hydraulic conditions. For example, if an area is not effective in conveying flow along the channel, the 2D model will compute still water or an area of flow circulation; if that area becomes effective as the flow conditions change, the 2D model will automatically account for this change. Therefore, the advantage of 2D models is that they more accurately simulate areas of complex flow patterns than 1D models do (U.S. Department of Transportation, 2009). The USGS selected a 2D model for this project because of the advantage of automatically and more accurately simulating areas of complex flow; it was an important consideration when looking toward a future dynamic flood-inundation mapping application that would automatically run hydraulic models during floods. Another advantage of a 2D model is the ability to compute multiple velocities and multiple water-surface elevations across any cross section. Additionally, advances in computing power, new model interface tools, and new 2D models have made simulation setup speed and runtime speed comparable to that of many $1 \mathrm{D}$ models. 


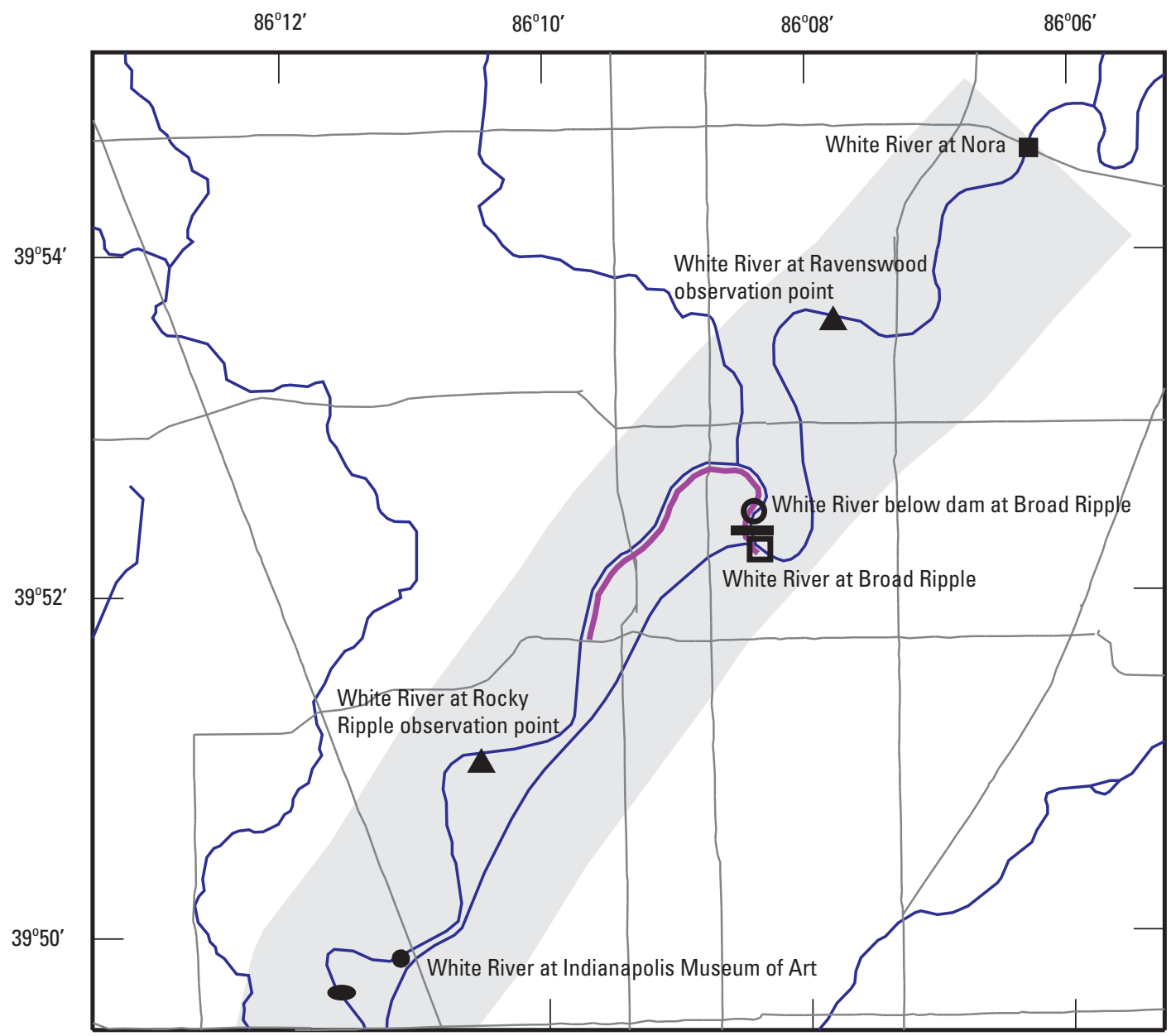

Base from U.S. Geological Survey digital data 1:100,000. 1983 Universal Transverse Mercator, Zone 16, NAD 83

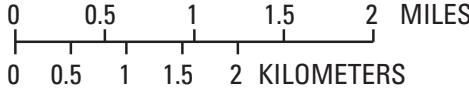

EXPLANATION

\begin{tabular}{|c|c|}
\hline Area of surface-water model & Low-head dam \\
\hline Levee & $\begin{array}{l}\text { Calibration point for water- } \\
\text { surface elevation }\end{array}$ \\
\hline $\begin{array}{l}\text { Streamgage, Natıonal } \\
\text { Weather Service river forecast } \\
\text { point, and calibration point for }\end{array}$ & $\begin{array}{l}\text { Streamgage (stage-only station) and calibration } \\
\text { point for water-surface elevation }\end{array}$ \\
\hline $\begin{array}{l}\text { water-surface elevation } \\
\text { Streamgage and }\end{array}$ & $\begin{array}{l}\text { National Weather Service river observation } \\
\text { point and calibration point for } \\
\text { water-surface elevation }\end{array}$ \\
\hline surface elevation & Streamgage (stage-only station) \\
\hline
\end{tabular}

Figure 2. Locations of U.S. Geological Survey streamgages, National Weather Service river observation and forecast points, and calibration points for water-surface elevation, White River, Indianapolis, Indiana. 
The model selected was the USGS FaSTMECH model. FaSTMECH analyzes 2D steady flow in channels and flood plains with a fixed bed (Berenbrock and Tranmer, 2008). FaSTMECH is a steady-state model using a structured curvilinear grid, based on 2D vertically averaged shallow-water equations (McDonald and others, 2001; Nelson and others, 2003; Simões and McDonald, 2004; McDonald and others, 2005a). The model solves a flow equation for the conservation of mass and momentum and incorporates terms for velocity, fluid density, gravity, pressure, and kinematic viscosity. The model also is capable of calculating the vertical distribution of the primary and secondary velocities about the vertically averaged velocity. These data help in calculation of bed-shear stress near the streambed for sediment-transport simulations. The FaSTMECH model, like other surface-water models, incorporates a parameter for friction to water flow, but it also includes a parameter for momentum transfer. Friction down the stream channel and over the flood plain is simulated with a dimensionless drag coefficient, which is constant and represents friction from the entire channel or flood plain. Typically, drag coefficients are around 0.003 for channels and around 0.07 for flood plains. Lateral momentum transfer due to flow turbulence is simulated with a term called lateral eddy viscosity (Berenbrock and Tranmer, 2008), which increases with streamflow and theoretically is calculated to be $0.01 \times$ mean depth $\times$ mean velocity. The lateral eddy viscosity can be increased until a stable model solution is obtained, but increases tend to decrease the variability in the modeled velocity (Conaway and Moran, 2004).

FaSTMECH was implemented by using the USGS MultiDimensional Surface-Water Modeling System (MD_SWMS), a pre- and postprocessing application for computational models of surface-water hydraulics (McDonald and others, 2005a). The system is both a tool and a framework that provides an easy-to-use interface to a variety of environmental hydraulic models. The tool is a Graphical User Interface (GUI) that allows the modeler to build and edit datasets of the modeling system's computational surface-water models. The framework links the GUI tool with the modeling applications. Additional information on the MD_SWMS interface and the FaSTMECH model used for this study can be found in McDonald and others (2001 and 2005a,b) and Nelson and others (2003).

\section{Data Requirements for Model Construction and Calibration}

Minimum data requirements for the FaSTMECH model include channel geometry, elevation of the flood plain, streamflow at the upstream model boundary, and water-surface elevation at the downstream model boundary (Barton and others, 2005). Additional data requirements for running flood watersurface simulations for this study included ground-elevation data for the contiguous flood plain of the White River and water-surface elevation data for flood peaks at multiple points along the study reach for model calibration.
The ground elevations of the contiguous flood plain associated with the White River channel in the study reach were obtained from existing DEM contour datasets supplied by the City of Indianapolis and the IMA. The equivalent groundelevation contour intervals of these data were $1 \mathrm{ft}$ throughout the IMA Virginia B. Fairbanks Art and Nature Park (fig. 1) and $2 \mathrm{ft}$ elsewhere in the study reach. The contour data were converted into raster data, then into point data of elevation values. A simple text data file of the elevation values was input into MD_SWMS, then an interpolation of the elevation data was generated within MD_SWMS. Elevation data for each computational node of the model were derived from the interpolated surface.

The elevation for the top of levees is depicted accurately by the DEM, but averaging of elevations from the grid of elevation data over a model cell during the creation of model input may artificially lower the top-of-levee elevation value input to the model. For example, the area of a model cell may include an elevation value for the top of a levee, as well as for the lower flood plain next to the levee. An average of these two values will generate an artificially low value for the top of the levee. To avoid the artificial lowering, the widths of the levees were increased artificially on the elevation grid to a distance greater than the width of model cells. In that way, at least one model cell would always correctly incorporate the elevation of the top of the levee.

The DEMs did not provide channel geometry below the water level in White River at the time the DEM ground-elevation data were collected. To estimate elevations for the channel bottom, a rectangular box-shaped channel was constructed. The width of the channel was set equal to the width of open water displayed on U.S. Geological Survey 1:24,000-scale topographic maps. The elevation of the channel bottom was derived from cross sections of White River streambed elevations reported in a flood insurance study by the U.S. Army Corps of Engineers (1983). The elevation of the channel bottom was increased at Broad Ripple (fig. 2) to represent a lowhead dam. The elevation for the top of the dam was obtained from the flood insurance study for the city of Indianapolis (U.S. Army Corps of Engineers, 1983).

Streamflow data at the upstream model boundary were obtained from the Nora streamgage by use of the station rating curve. A rating curve shows the relation between river gage height and streamflow at the gage location (Rantz and others, 1982). A downstream stage record at the IMA was not available. To approximate the downstream stage record, an extrapolation of the stage record at the Nora streamgage was used. The stage at the IMA was calculated by subtracting $29.1 \mathrm{ft}$ from the values for stage at the Nora streamgage. The value of $29.1 \mathrm{ft}$ was used because it represents the drop in land-surface elevation between the upstream and downstream ends of the model. 
Williams Creek, a tributary to the White River (fig. 1), adds to streamflow in the White River at a point downstream from the Nora streamgage. The tributary flow was not simulated by the surface-water model, but the error introduced by not including the tributary flow was not considered significant. The drainage area of Williams Creek was less than 2 percent of the drainage area associated with the Nora streamgage. Therefore, the amount of flow contributed by Williams Creek was expected also to be a small proportion of the flow in the White River. The inclusion or omission of the tributary flow for this particular reach has a negligible effect on simulated water-surface elevation.

An initial water-surface elevation for the modeled reach was required. The initial surface was estimated by using a form of the step method (Chow, 1959). Inputs to the step method were upstream flow rate, downstream stage of the flood peak, and a drag coefficient. The drag coefficient was chosen to be somewhat greater than the expected value to ensure that the calculated initial water surface was sufficiently high to cover all potentially flooded areas.

Initial drag coefficients for the actual model simulations were calculated from Manning roughness coefficients used in the Indianapolis flood insurance study (U.S. Army Corps of Engineers, 1983). The Manning roughness coefficients were converted to drag coefficients by using the following equation (Kenney, 2005):

$$
C_{d}=\frac{\left(\frac{n}{1.515}\right)^{2} g}{H^{1 / 3}}
$$

where

$$
\begin{array}{cl}
C_{d} & \text { is drag coefficient, } \\
n & \text { is Manning's roughness coefficient, } \\
g & \text { is acceleration of gravity, in feet per second } \\
& \text { squared, and }
\end{array}
$$

Two values for $C_{d}$ were calculated and used in the model. To obtain the two values, an average value of $n$ for the flood plain and an average value for the channel used by the flood insurance study (U.S. Army Corps of Engineers, 1983) were determined. Then, equation 1 was used to convert each average to a value of $C_{d}$ for use in FaSTMECH simulations.

An initial estimate of lateral eddy viscosity was required. A value was calculated for conditions in the flood plain, as opposed to conditions in the stream channel. Lateral eddy viscosity simulates processes associated with turbulence, and turbulence in flood-plain flow was a more critical factor to simulate than turbulence in the stream channel. On the basis of local knowledge and past FEMA studies, the initial estimate was obtained by assuming that the mean depth of water in the flood plain to be $4 \mathrm{ft}$ and the mean velocity to be $3 \mathrm{ft} / \mathrm{s}$ at the flood peak. By using the equation for estimating lateral eddy viscosity $(0.01 \times$ mean depth $\times$ mean velocity), the initial value was calculated to be $0.12 \mathrm{ft}^{2} / \mathrm{s}$.
The model grid used in FaSTMECH was a curvilinear orthogonal coordinate system with a user-defined centerline. The grid centerline was defined interactively in MD_SWMS to approximate the mean flow streamline in the modeling reach (Nelson and others, 2003). The model grid approached the appearance of a rectangular model grid as used in groundwater models such as MODFLOW (Harbaugh and others, 2000), but the boundary of each model grid cell can be defined by slightly curved lines. The capacity to curve the model grid allows for the model-grid network to more efficiently follow a curving river valley. An example of the appearance of the FaSTMECH grid lines can be seen in Berenbrock and Tranmer (2008). The model grid used to subdivide the White River valley into small individual cells represents an area of about $7.5 \mathrm{mi}$ long and $1.4 \mathrm{mi}$ wide. Each cell averages $50 \mathrm{ft}$ by $50 \mathrm{ft}$, and nodes are located at the corners of each grid cell. Ground elevations and drag coefficients for the flood plain and channel were input for each of 104,139 model nodes associated with the grid. The model outputs water-surface elevation, velocity, and depth at each of the nodes. The nodes at the downstream end of the modeled area shown in figure 3 illustrate the capacity of the node network to follow a curved stream valley and to sample adequately the variation in ground surface.

The following water-surface elevation data were available for model calibration: (1) USGS streamgages (listed in downstream to upstream order) 03351201 White River at Indianapolis Museum of Art, IN; 03351071 White River below Dam at Broad Ripple, IN; and 03351060 White River at Broad Ripple, IN, and 03351000 White River near Nora, IN; (2) manually observed stage at NWS observation points White River at Ravenswood (RVNI3) and White River at Rocky Ripple (RRPI3); and (3) high-water marks set by USGS at the Indianapolis Museum of Art (fig. 2).

\section{Model Calibration and Performance}

The model was calibrated by changing the model design, and not, as is typically done, by adjusting the drag coefficients for the stream channel and flood plain. The initial values for drag coefficients were held constant during calibration because of uncertainties in the stream-channel geometry. Bathymetric surveys of the channel bottom had not been done; therefore, the actual shape of the channel bottom was unknown. Improvements in the elevation of the simulated water-surface elevation could be accomplished by changes in the streamchannel geometry at multiple locations and not necessarily by changes in values for drag coefficient. Use of the initial estimates of drag coefficients as calibrated values should not introduce significant model error because the initial values were probably close to actual values. The initial estimates were based on calibrated values from another surface-water model (U.S. Army Corps of Engineers, 1983). 


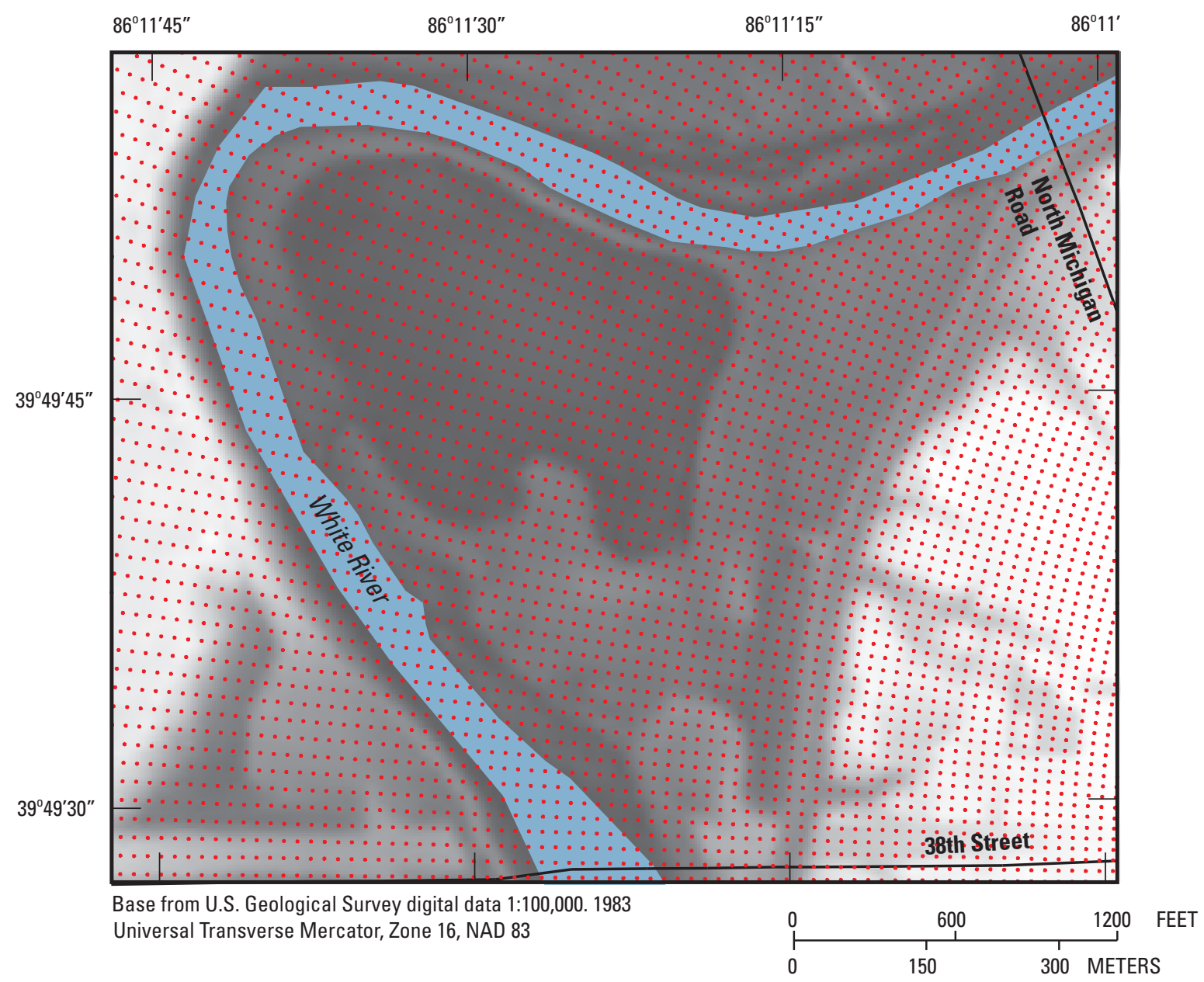

\section{EXPLANATION}

Land-surface elevation, in feet above NAVD 88

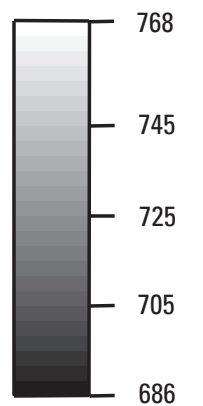

Location of a computational node for the surface-water model

Figure 3. Distribution of model nodes at southern end of modeled area, White River, Indianapolis, Indiana. 
The most effective change to model design for improving model calibration involved decreasing the model grid cell size from 50 by $50 \mathrm{ft}$ to 20 by $20 \mathrm{ft}$. At 50 -ft cell size, the simulated water surface was generally higher than the surface described by high-water marks. The high-water marks were actual data obtained by field observation. The decrease in cell size lowered the simulated water-level surface to an elevation more representative of the known elevation at the high-water marks. The improvement was probably the result of more model nodes representing the narrow stream-channel sections. At a few sections, when the 50 -ft cell size was used, the stream channel became so narrow that only one or two model nodes were representing flow down the channel. So few nodes resulted in an extremely coarse model grid and an artificial increase of the simulated water surface upstream of the narrow section. Reducing the model cell size to 20 by $20 \mathrm{ft}$ increased the number of nodes simulating narrow channel sections to four or five nodes and reduced the simulated water-level surface.
Further reduction in the simulated water-level surface was accomplished by lowering the entire stream-channel bottom by $1 \mathrm{~m}$, or $3.281 \mathrm{ft}$, from the values shown in the flood insurance study (U.S. Army Corps of Engineers, 1983). Lowering the channel bottom to lower the simulated waterlevel surface was recommended by Richard McDonald of the U.S. Geological Survey Geomorphology and Sediment Transport Laboratory (oral commun., July 2007). McDonald considered a uniform lowering justifiable on the basis of uncertainties in the geometry of the simulated channel bottom. The bottom of the stream channel was represented by a rectangular box instead of by channel-bottom elevation data from bathymetric surveys. McDonald also recommended further lowering the end section of the stream channel bottom by about $10 \mathrm{ft}$ (fig. 4). Lowering of the channel bottom was effective in lowering the simulated water surface to an elevation similar to that measured at the furthest downstream high-water mark. Lowering the downstream stage value instead of the channel bottom to improve the match between simulated and measured water-surface elevation was not effective. $86^{\circ} 11^{\prime} 15^{\prime \prime}$

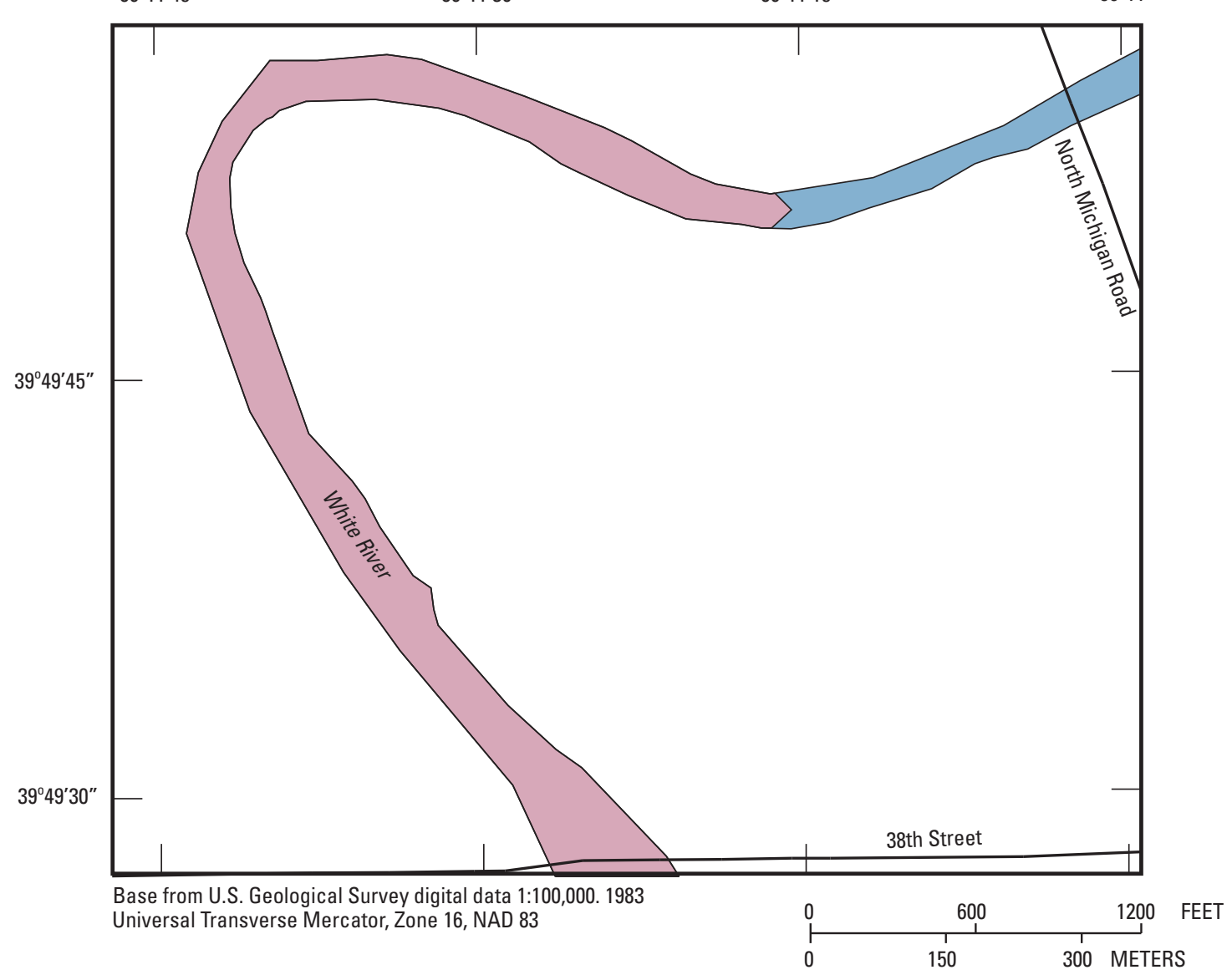

Figure 4. Area where the channel bottom was lowered by 10 feet in the surface-water model, White River, Indianapolis, Indiana.

\section{EXPLANATION}

Area where channel bottom was lowered 
The model calibration process consisted of (1) inputting values for model parameters, (2) solving the flow equation by an iterative process until the simulated and measured flow rates were within 3 percent of each other, (3) observing the agreement between simulated and measured water-surface elevations at high-water marks, and (4) adjusting the model design (as previously described) until the simulated and measured water-surface elevation values were in reasonable agreement. The values for the model input parameters that produced a stable and representative solution are as follows:

Drag coefficient, flood plain .... 0.05 (dimensionless)

Drag coefficient, stream channel.....0.003 (dimensionless)

Lateral eddy viscosity $0.10 \mathrm{~m}^{2} / \mathrm{s}$

The root mean square error between simulated and measured water-surface elevations for the storm at the end of March 2007 was $1.47 \mathrm{ft}$. The individual residuals between simulated and measured values plotted against position along the River (fig. 5) depict little positive or negative bias.

The iterative solution process during calibration simulations encountered mathematical instabilities in solving for flow in the flood plain and around the low-head dam. The instabilities could not be eliminated by increasing the lateral eddy viscosity, a tactic that tends to support a more stable solution. A stable solution could be achieved only by eliminating the low-head dam where water was abruptly changing in elevation. Instead of the low-head dam, a ramp from the top of the low-head dam to the channel bottom downstream of the dam was simulated. The ramp provided an incremental change - rather than an abrupt change - in the elevation of the channel bottom, which helped to stabilize the solution process. Also, bridge piers were not simulated in order to avoid any potential instability introduced by the piers.

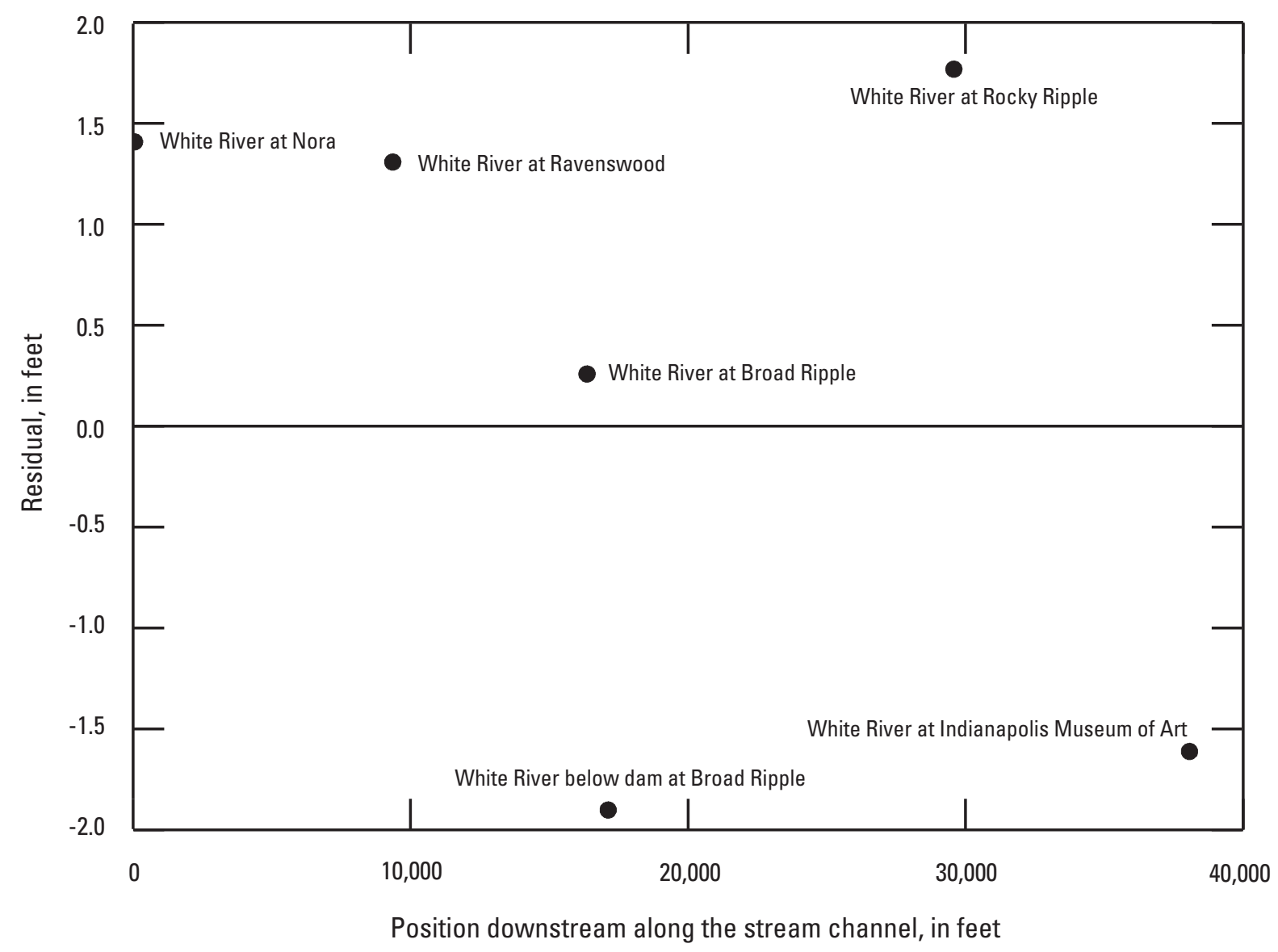

EXPLANATION

- Plotting position for a residual

Figure 5. Residuals of simulated and measured water-surface elevation along the White River, Indianapolis, Indiana. 


\section{Model Limitations}

Computer simulations can only approximate actual conditions, and these approximations introduce error into the model output. The overall error introduced by the approximations made in this modeling study can generally be measured by the mean absolute error, which was an acceptable $1.47 \mathrm{ft}$. This section provides more detail about how and where limitations in model design and input affect predicted water-surface elevations. Model limitations are presented in the following list.

- A transient flow process (a flood) was represented by a steady flow (or steady-state) simulation. The watersurface elevation predicted by a steady-state solution should adequately represent the stage at the peak of a flood because White River stage changes slowly at the peak of flow. Stage changed less than $0.2 \mathrm{ft}$ during a 12-hour period around the peak flow of the March 2007 storm. The long period of near-peak flow allows for water to transfer laterally from the stream channel to the flood plain and achieve a similar elevation throughout. The water-surface elevation resulting from a nearly complete redistribution of water closely approaches the elevation predicted by a steady-state simulation that assumes infinite time for water redistribution.

- Channel geometry for the White River was approximated by a channel in the shape of a rectangular box instead of a channel that varies according to actual channel geometry. This approximation would severely affect the predicted water-surface elevation at low flows, but not at flood flows. Natural channels exhibit features such as thalwegs. During low flows, the flow in a thalweg may be a major part of total flow. During floods, the vast majority of total flow is in the channel cross section above the thalweg and in the flood plain. The channel cross section above the thalweg was represented adequately by a rectangular box. The flood plain was represented adequately by the $2-\mathrm{ft}$ land-surface elevation contours on which the floodplain surface was based. The elevation of the channel bottom at the downstream end of the model was adjusted downward to improve the match between simulated and measured water-surface elevation. The lowering was considered artificial, but it was effective in improving the simulated water-level elevation for all three calibration storms.

- River stage at the downstream end of the model was not available but was estimated to be $29.1 \mathrm{ft}$ lower than stage at the Nora streamgage. In a steady-state simulation, flow throughout the channel was the same; therefore, changes in elevation of the water-level surface were controlled mostly by changes in the slope of the land surface. Errors from this assumption were expected to be much less than the overall error in predicted elevation of the water-level surface of $1.47 \mathrm{ft}$.
- The low-head dam and bridge piers were not simulated. The absence of these features in the calibrated model resulted in predicted water-level surfaces to be in error, possibly by a foot or more, as seen in figure 5 .

The error in model predictions can be qualitatively evaluated by observing the flood images presented subsequently in this report. For example, the error associated with the image of the 14.5-ft flood stage can be evaluated by comparing the flooded area shown in the images from the $13-\mathrm{ft}$ stage to those of the 16-ft flood stage. This range in flood elevations was determined by assuming the predicted elevation can be as much as $1.5 \mathrm{ft}$ above or below the image for the 14.5 -ft stage flood. The value of $1.5 \mathrm{ft}$ was chosen because it was close to the mean absolute error of $1.47 \mathrm{ft}$ for the calibrated model.

\section{Development of Flood Images}

Water surfaces were developed initially for a range of river stages at the Nora streamgage: $11.4 \mathrm{ft}$ (estimated bankfull stage), 12.0, 13.0, 14.0, 15.0, 16.0, 17.0, 18.0, 19.0, 20.0, 21.0 , and $22.4 \mathrm{ft}$ (computed from the peak streamflow of the March 1913 flood). Streamflows corresponding to the various stages were obtained from the most recent rating curve in use at that streamgage. Water-surface elevations at the downstream end of the study area for each streamflow were obtained by subtracting $29.1 \mathrm{ft}$ from the values for stage at the Nora streamgage, just as was done for the calibration of the model.

Areas of inundation for each of the river stages were determined by subtracting the land-surface elevation data from the water-surface elevation data, resulting in raster data that showed the extent and the depth of flood. Land-surface elevation data were obtained from the DEM datasets supplied by the City of Indianapolis and the IMA. The inundated areas associated with the each water surface thus became flood images that were saved as raster data files.

\section{Dissemination of Flood-Inundation Map Libraries}

The flood images were disseminated through the following means: (1) digital maps showing the inundated areas for the IMA Virginia B. Fairbanks Art and Nature Park, (2) raster data files, (3) an interactive map server application housed on a local USGS server, and (4) the NWS AHPS Web site and USGS Flood-inundation Mapping Initiative (FIMI) Web site (http://water.usgs.gov/osw/flood_inundation/). Dissemination methods 1, 2, and 3 were developed in a phased approach in order to deliver flood-specific operational information to the project cooperators and Silver Jackets members prior to the broader release of the flood images through method 4 . 
A map showing flood inundation for the IMA Virginia B. Fairbanks Art and Nature Park was created for each of the flood images. The maps were created by combining each flood image with aerial photographs obtained from the Indiana Spatial Data Portal (ISDP; 2005). Each map was created in a Portable Document Format (PDF); this format was selected so that IMA personnel could quickly access a map without needing to have highly technical knowledge or software for viewing GIS-based files. The maps include estimates of depth of water by a color-coded graduation (a darker color indicates greater depth); these maps are compiled in appendix 1.

Each of the flood images for the entire study reach was saved in a common file format called a "raster data file." A raster data file is a rectangular array of regularly sampled values, known as pixels. Each pixel (picture element) has one or more numbers associated with it, specifying a color in which the pixel should be displayed (Boston University, 2009). The raster data files allowed the City of Indianapolis, IMA, and IDHS to use the flood images in their own GIS applications during subsequent events.

The flood images also were made available to project cooperators through a local map server. The map server provided the flood images in a Web-based, interactive format accessible through a Web browser (an example screenshot is shown in fig. 6). The browser allowed users to view the flood images as inundation areas overlain on aerial photographs from ISDP, including depths, for the entire study reach. The map server software also allowed users to zoom into smaller areas of interest. The map server Web address was first made available only to the City of Indianapolis, IMA, and IDHS because the server access speed was slow, owing to internal Internet security protocols and a lack of bandwidth availability to the external users. This application was a stopgap measure until the flood images were available from the NWS AHPS Web site and the FIMI Web site.

Before the flood images can be made available through the NWS AHPS Web site (an example screenshot is shown in fig. 7), several requirements must be met in a phased approach. These phases include (1) planning; (2) hydrologic, hydraulic, and geospatial analyses; (3) AHPS implementation; and (4) map maintenance (National Oceanic \& Atmospheric Administration, 2009). At the time this report was written, this project was considered to be in phase 2 . When the decision was made to post flood images on the AHPS, the pilot project was well under way and had already produced a set of map libraries by use of the calibrated model. Therefore, the decision was made to quickly review the planning phase and start the review process at phase 2 immediately.

As a result of discussions held at several review meetings, some of the information associated with the pilot project needed to be updated and modified in order to meet the requirements for continuing the review process. These updates and modifications included reestablishment of the study boundary, modification of the levee data, compilation of the bridge decking and low-steel elevation data, and validation of the model at flows greater than and less than the calibration flow. The western boundary of study area was adjusted to College Avenue (fig. 1) to show maximum impact of flooding and minimize the uncertainty resulting from the future levee project just downstream from College Avenue. The top elevations of levees in the model were adjusted to reflect the as-built drawings obtained from the City of Indianapolis. The bridge decking and low-steel elevation data were needed to adjust the GIS layers to show whether the bridge was inundated or not. All of the bridge data were obtained from the flood insurance study from FEMA and the City of Indianapolis. Two additional model runs were performed, one greater than and one less than the calibration flow of 17 - $\mathrm{ft}$ stage, in order to validate the model. The results from these additional model runs indicated that simulated and measured water-surface elevation values were in reasonable agreement.

After the updates and modifications were applied, the completed GIS datasets from phase 2 were submitted for a level 1 quality control (QC) review. This QC review was then followed by a review-comment-revise/response cycle until it was determined that the submittal was ready to move on to phase 3. As stated earlier, at the time this report was written, the submittal for the pilot project was at phase 2, level 1 QC review cycle. At phase 3 of the process, all of the datasets that were approved through phase 2 will be provided to the AHPS contractor for further review and testing. Additional review by the local Weather Forecast Office will be done when the datasets are posted on the non-public AHPS developmental Web server before the final release to the public AHPS Web server. Finally, the last part of the process, phase 4, involves the maintenance of datasets. Any changes to the existing hydraulic settings and conditions could potentially result in changes in the flood response of the studied stream, changes in the flood impacts in the surrounding flood plain, or a combination of both. Therefore, a maintenance program should include ongoing verification of the datasets in the wake of significant flooding (National Oceanic \& Atmospheric Administration, 2009).

The flood images also were made available through the FIMI Web site (an example screenshot is shown in fig. 8), a national USGS Web portal linking current and future floodinundation projects. This portal was designed to help the USGS maintain a uniform user interface to inundation products for various stakeholders and provide a single entry point for all USGS flood products. To develop a consistent visual and electronic file format for all USGS inundation-map products and to meet the goals and objectives of the FIMI, flood images are being made available in several formats including GIS, Keyhole Markup Language (KML), and PDF. A set of these maps is provided in appendix 2. 


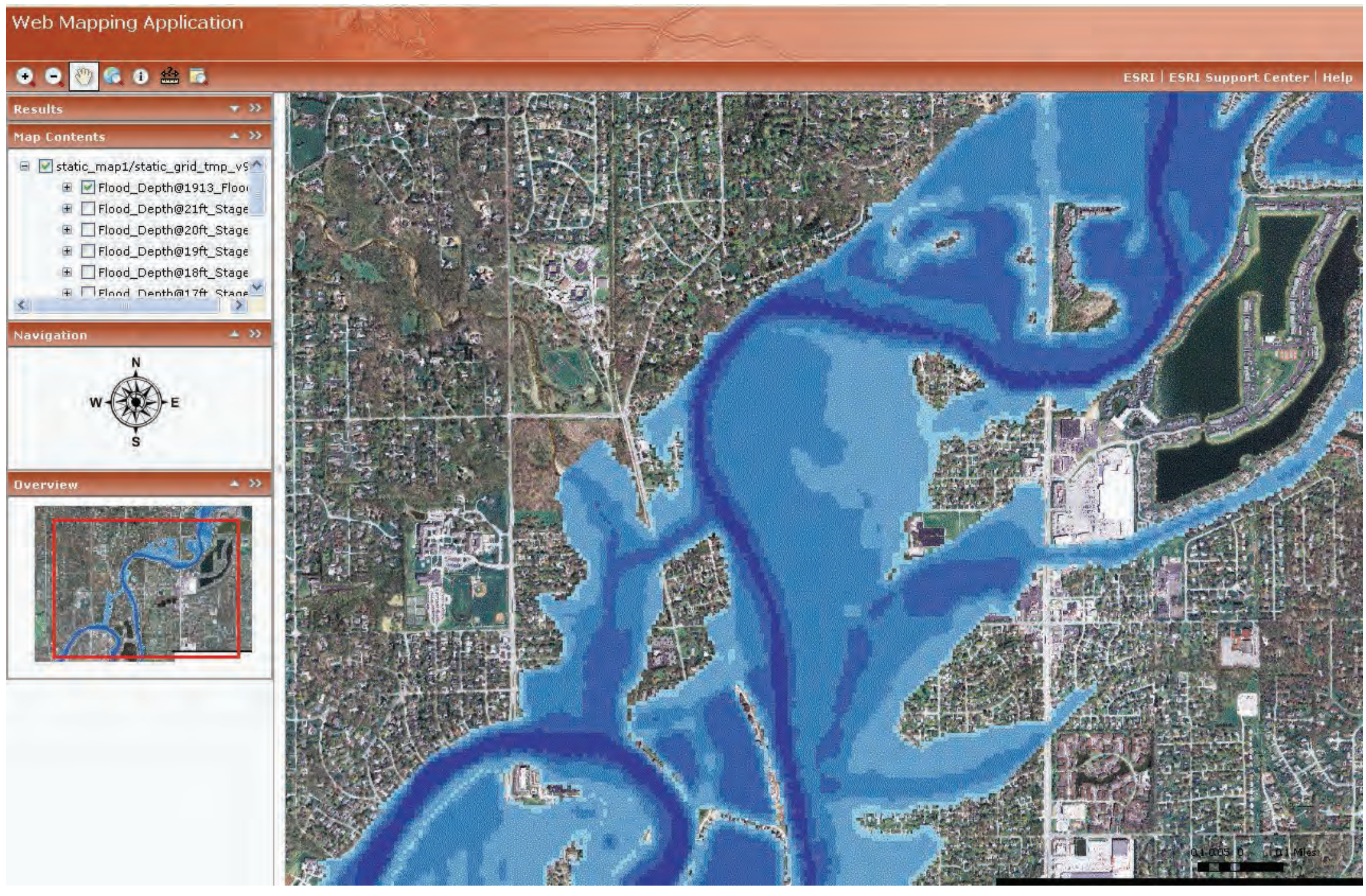

Figure 6. Example screenshot from a local map server showing a flood image from the White River pilot study, Indianapolis, Indiana. 


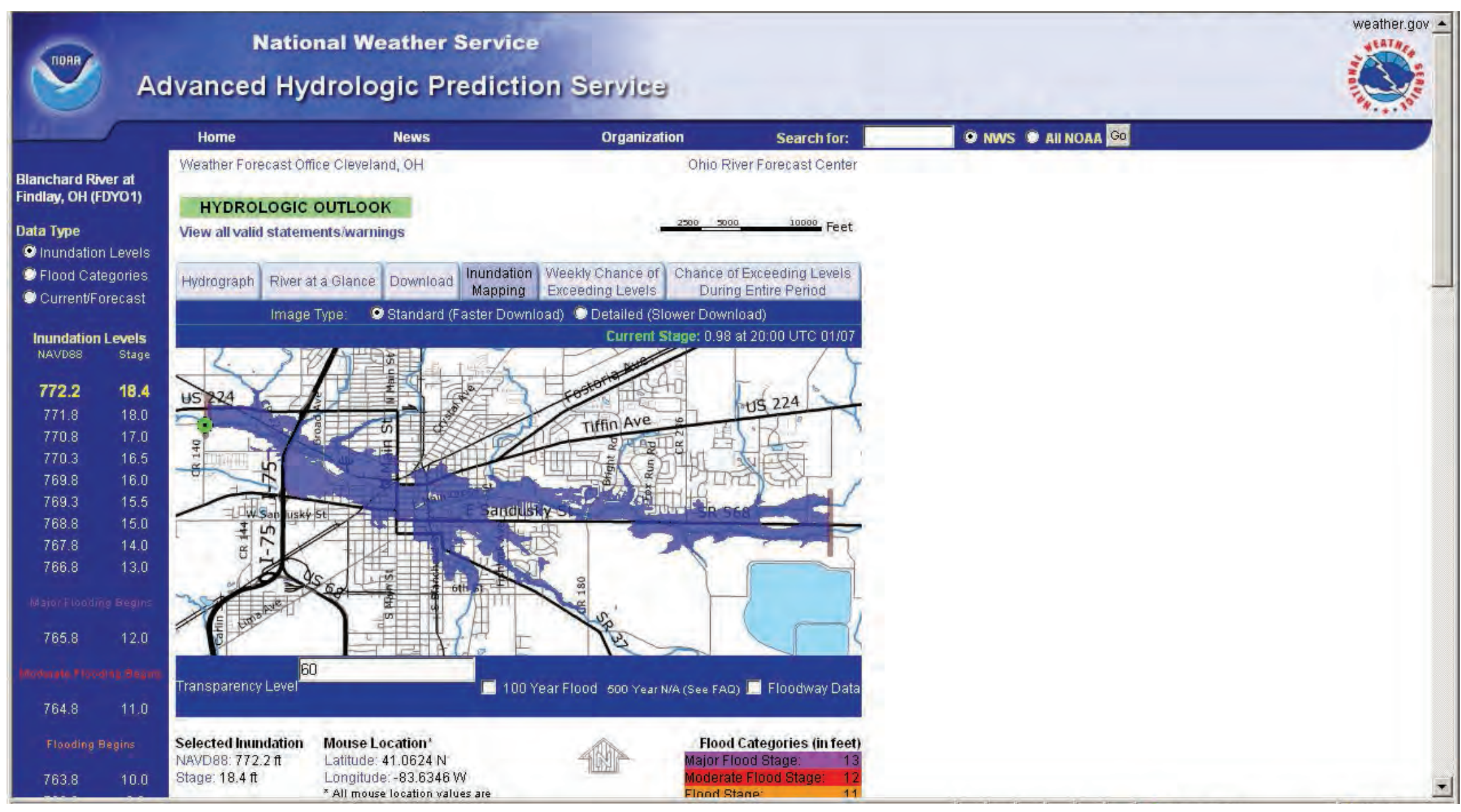

Figure 7. Example screenshot (showing inundation along the Blanchard River, Findlay, Ohio) from the National Weather Service-Advanced Hydrologic Prediction Service Web site. 


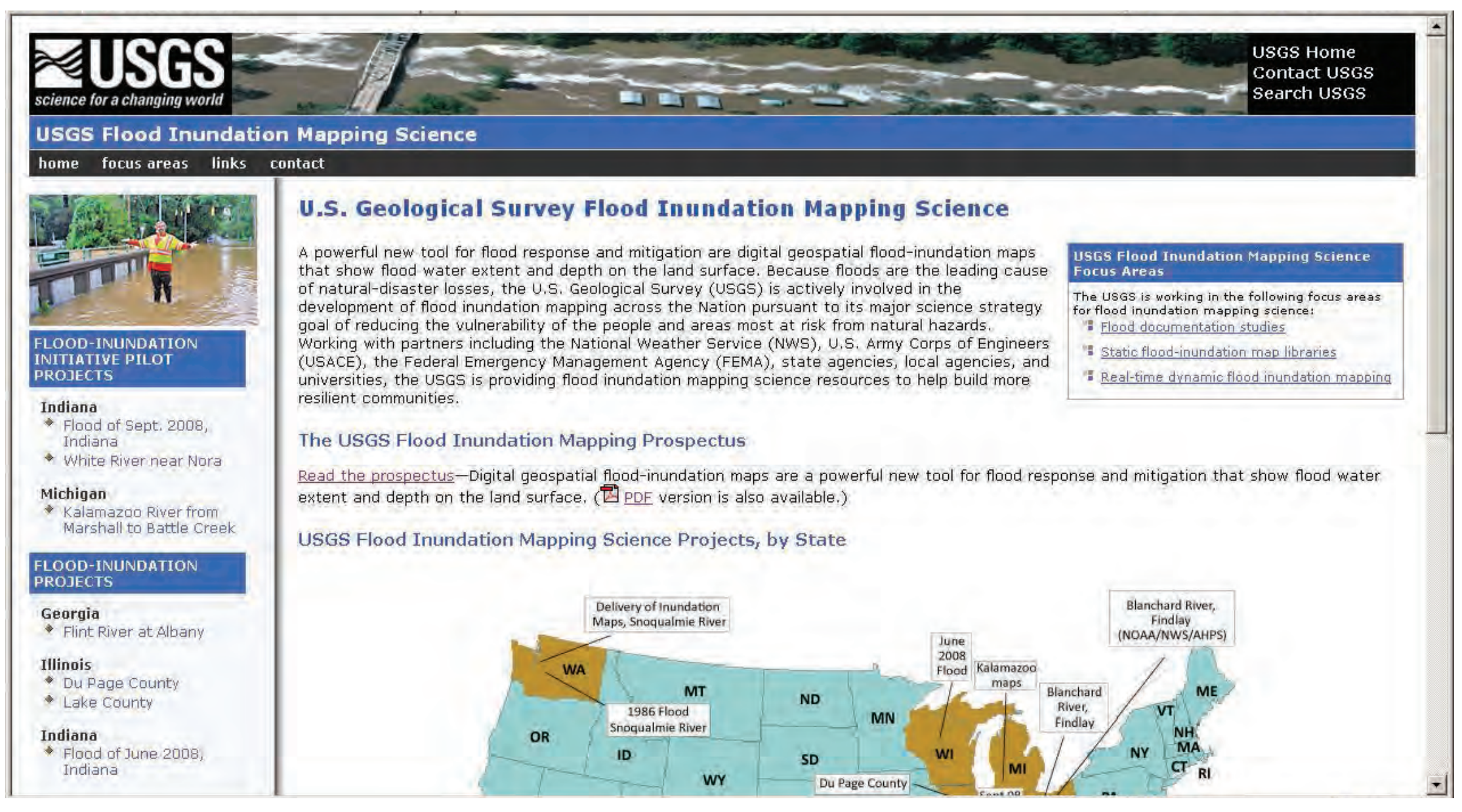

Figure 8. Example screenshot from the U.S. Geological Survey Flood Inundation Mapping Initiative Web site. 


\section{Flood-Loss Estimate}

From the outset of the pilot project, a flood-loss estimate demonstration was to be a major component. Estimating losses is essential to decision making at all levels of government, providing a basis for developing mitigation plans and policies, emergency preparedness, and response and recovery planning (Federal Emergency Management Agency, 2009c). The Polis Center completed a flood-loss estimate using FEMA's HAZUS-MH software to demonstrate the utility of the flood images in flood-loss estimation.

\section{HAZUS-MH}

HAZUS-MH is a nationally applicable standardized methodology that can be used to estimate potential losses from earthquakes, hurricane winds, and floods. HAZUS-MH was developed by the FEMA under contract with the National Institute of Building Sciences. HAZUS-MH uses GIS software to map and display hazard data and the results of damage and economic-loss estimates for buildings and infrastructure (Federal Emergency Management Agency, 2009c).

HAZUS-MH provides three levels of analysis based on the level of analytical effort and expertise of the user. Users can improve the accuracy of HAZUS-MH loss estimates by furnishing more detailed data about the hazard being studied (in this case, flooding) and more detailed building inventory data. The following discussion of these levels was taken from the HAZUS-MH Analysis Levels Web page (Federal Emergency Management Agency, 2009b).

- Level 1 analysis provides a basic estimate of earthquake, flood, or hurricane wind losses based on national databases and expert-based analysis parameters included in the HAZUS-MH software. This is commonly referred to as an "out-of-the-box" or "default” loss estimate.

- Level 2 analysis provides more accurate loss estimates by including detailed information on local hazard conditions and/or by replacing the national default inventories with more accurate local inventories of buildings, essential facilities, and other infrastructure. (For the pilot project, the Polis Center used a level 2 analysis for the flood-loss estimate.)

- Level 3 analysis includes all the hazard and inventory improvements in a level 2 study in addition to expert adjustment of analysis parameters (such as mathematical formulas that relate damage to structures to flood depth).
To simulate riverine flooding in a HAZUS-MH level-1 analysis, HAZUS-MH makes use of a simple hydraulic model based on Manning's equation. The model generates stream cross sections from a DEM provided by the USGS National Elevation Dataset (NED); users may supply their own DEMs or use a combination of their DEM and the NED (Muthukumar, 2005). Manning's equation is used to determine flood elevations at the cross sections, and the flood surface is determined by interpolating elevations between cross sections (Muthukumar, 2005). Users can input a discharge into the model for their study reach. If no discharge is input, HAZUSMH implements a hydrologic analysis that uses built-in regression equations to determine discharge-frequency relations for return periods of 2, 5, 10, 25, 50, 100, and 500 years for each study reach; regression results are adjusted by using data from USGS streamgages (Muthukumar, 2005). Rainfall runoff modeling is not implemented, and no adjustments are made for urban conditions (Muthukumar, 2005). Structures in the channel such as bridges, dams, and culverts are not modeled.

For a level 1 HAZUS-MH flood analysis, building inventory data are supplied at the level of national census blocks. A census block is an area bounded on all sides by visible and/ or nonvisible features shown on a map prepared by the Census Bureau; a block is the smallest geographic entity for which the Census Bureau tabulates decennial census data (Temple University, 2010).

A HAZUS level 1 analysis is useful for regional floodloss estimates. However, for smaller geographic areas (such as a single community), the approximate nature of the riverine model can cause errors in the extent and depth of the inundated area for a given discharge that then affect the estimate of losses within the inundated area. Further, the building inventory data associated with a level 1 analysis evenly distributes structures by type (for example, single-family residential) throughout a census block (Polis Center, 2008). Because structures rarely are distributed evenly within a block, the analysis can result in substantial errors in a loss estimate for smaller geographic areas. For small geographic areas, the accuracy of flood-loss estimates can be improved substantially by means of a level 2 flood analysis, whereby detailed hydraulic modeling is done to produce flood images, those image files are imported into the HAZUS-MH analysis, and the national default inventories are replaced by more accurate local inventories of buildings, essential facilities, and other infrastructure. 


\section{Pilot Project HAZUS-MH Level 2 Analysis}

The Polis Center used one of the flood-inundation images developed for the White River pilot project to perform a level 2 flood-loss analysis with HAZUS-MH. The following discussion is based on a report submitted to the Indiana Silver Jackets by the Polis Center (2008).

The level 2 analysis was completed for part of the pilot project study area (fig. 1) that consists mostly of the Ravenswood neighborhood, which was selected by the Polis Center because of frequent flooding by the White River. Building inventory data for the analysis were obtained by the Indianapolis Mapping and Geographic Infrastructure System (IMAGIS). The IMAGIS data included the structure footprint and centroid location for each individual building, as well as street centerlines. The dollar value of building structure and content was provided by the Computer Assisted Mass Appraisal (CAMA) dataset maintained by the Indiana Department of Local Government and Finance. The CAMA data for the analysis were modified for HAZUS-MH compliance by adding multiple data fields needed for the analysis, removing multiple fields that were not compliant, and modifying several fields. The CAMA data then were joined to buildingcentroid data to create a HAZUS-MH "user-defined facility" file for the Ravenswood neighborhood. User-defined facility files contain the estimated dollar value of building structure and contents that HAZUS-MH uses to compute flood-damage loses. The IMAGIS data included a total of 1,839 buildings for the level 2 analysis. Of those structures, the greatest number of units-1,737-were classified as Single Family Dwelling. HAZUS-MH classifications for the remainder of structures were Multi-Family Dwelling, Duplex, Triplex-Quadriplex, 39 units; Institution Dormitory, 13; Retail Trade, 26; Personal and Repair and Professional Technical Services, 11; Medical Office/Clinic, 5; Entertainment and Recreation, 5; and Parking, 3. The estimated total value of the building structures was approximately \$559 million, and the estimated total value of building contents was approximately \$279 million.

The level 2 flood-loss estimate for the Ravenswood neighborhood is based on the HAZUS-MH version "MR3." This version includes a significant advancement in HAZUS$\mathrm{MH}$ : the ability to directly import a user-provided GIS flood depth raster data file into a loss estimate. A GIS raster data file was created from the previously mentioned FaSTMECH modeling effort for a stage of $17 \mathrm{ft}$ at the Nora streamgage. This raster data file then was imported into HAZUS-MH and used in conjunction with the IMAGIS/CAMA building and content data for the level 2 flood-loss analysis of the Ravenswood neighborhood. The raster data file used for the model simulated an actual flood of March 2007 (the flood also used to calibrate the FaSTMECH model). This flood was estimated to be between a 10- and 20-percent-chance flood (which corresponds to a 10-year and 5-year recurrence interval, respectively).
The analytical results showed that 361 buildings were within the inundated area. HAZUS-MH calculated that 222 , or 61 percent, of those buildings sustained damage as a result of the depth of water at the building location and the building's physical characteristics, such as foundation type and first-floor elevation. (These attributes were part of the IMAGIS dataset.) The estimated total value of loss associated with the building structures was approximately \$5.6 million, and the estimated total value of loss associated with the building contents was approximately \$2.8 million (Polis Center, 2008).

\section{Development of a Dynamic Flood Mapping Application}

The third phase of the White River pilot study was the development of a dynamic flood mapping application that would, by using near real-time USGS streamgage data and NWS flood forecast data, automatically run a hydraulic model and produce flood images in a GIS format during a flood. This phase of the study resulted in a composite application that used multiple, independent Web services to generate the flood-inundation maps and to estimate flood-related property losses. The composite application provided flood-inundation maps and flood-loss estimates through a single Web-based GUI that can be accessed by using an Internet browser. The principal investigator for this phase of the pilot study was an interagency team consisting of the USGS, the NWS, the Polis Center, and the Indiana University Community Grids Lab.

\section{Dynamic Application Requirements}

The interagency team developed the following list of requirements for the dynamic application:

- The application would, through automated computer processes, monitor near-real-time river conditions and automatically start when a predetermined threshold was reached. The threshold would be based on the streamflow at which flooding would begin to impact human activities (for example, flood low-lying roads). This streamflow was determined to be $11,000 \mathrm{ft}^{3} / \mathrm{s}$ at the Nora streamgage. The application would continue to run as long as the streamflow equaled or exceeded $11,000 \mathrm{ft}^{3} / \mathrm{s}$.

- The application would run approximately hourly and would output both near-real-time and forecast flood images based on the most current USGS streamgage data and NWS flood forecast data.

- The application would use the output flood images in conjunction with flood-loss estimate systems to output not only the flood maps but also estimated flood losses tied to a particular observed or forecast flood image. 
- The flood images and flood-loss estimates would be output in a Web GUI so that emergency managers could quickly access the information without needing specialized knowledge of geographic information systems or flood-loss estimation systems.

- The application would utilize, to the extent possible, existing programs and services linked together by a common computer architecture.

- The application would be designed to be expandable in scope and scale; for example, at some point a levee breach function might be added. "Expandable in scale" refers to the application being usable for any flood-prone area and for longer and/or multiple stream reaches.

- The application would not be dependent on the background workings of any particular service or system. For example, new hydraulic models could be used without having to change major application components; a Web service such as the NWS flood forecast could undergo a very large change in how forecasts were derived, but provided that the end output of the service - in this case, flood forecasts - was preserved, the change would be transparent to the application.

To meet these requirements, the project team decided to use Service-Oriented Architecture to merge the application service and system components to provide dynamic flood images and flood-loss estimates.

\section{Service-Oriented Architecture}

Service-Oriented Architecture (SOA) is a collection of computer services that communicate with each other. In this context, a "service" is a function that is well defined, selfcontained, and independent of the context or state of other services (Barry and Associates, 2010). The communication can involve simple data passing, or it can involve two or more services coordinating some activity.

For a SOA that is based on Web services, Extensible Markup Language (XML) is typically used to allow the services to pass data and information to one another. A markup language is a computer language used in encapsulating and describing data and its attributes. A markup language embeds processing instructions (called tags) in electronic documents so that they are styled accurately and presented as the original document irrespective of the computer platform, operating system, or application program used. Tags also allow inclusion of additional descriptive information (called metadata) about the encapsulated data to facilitate exchange of complex data types between different systems (BusinessDictionary.com, 2010). XML was designed to carry data, not to display data (W3schools, 2010), and is a reliable and robust method of data communication between Web services.
By means of XML, a Web-based SOA application can use data generated from stand-alone services and combine those data into a new service or services to create a product not available from any one of the stand-alone services. SOA therefore was ideally suited for combining near-real-time streamgage data, flood forecast data, and flood-loss estimation services to produce a new Web service that provides floodinundation maps based on actual and forecast flooding and flood losses associated with that flooding.

\section{Dynamic Application Integration and Testing}

The dynamic application used SOA to link the following computer services together to produce a new Web service designed to provide, through an easy-to-use GUI, flood-inundation maps and associated flood-loss estimates (Polis Center, 2009):

- NWS AHPS Web flood forecasting service.-Observed and forecast stage and streamflow data were obtained from AHPS for the flood forecast point White River at 82nd Street Bridge near Nora (NWS designation NORI3), which was colocated with the Nora streamgage. The USGS streamgage was the source of the observed data that NWS provided through the AHPS Web service. NWS provided forecast stage and streamflow data for NORI3 up to 5 days out. Forecast data values were at 1 -hour intervals. The relevant output of this service was observed and forecast stage and streamflow values, in XML format.

- CGNS input service.-CGNS is an abbreviation for Computational fluid dynamics General Notation System. The CGNS Input Service was developed to automatically input the boundary conditions into the FaSTMECH hydraulic model. Among the CGNS Input Service components were (1) Perl computer programming language scripts that obtain the XML file of current and forecast data from the NWS AHPS flood forecasting Web Service and (2) C++ computer programming language scripts. The Perl scripts passed the data obtained from the AHPS flood forecasting services to the $\mathrm{C}++$ scripts; those scripts then created the FaSTMECH model CGNS input files. The model boundary conditions consisted of streamflow from the Nora streamgage/flood forecast point and the stage at the downstream model extent, as described in the "Development of a Static Flood-Inundation Map Library" section of this report. This stage was estimated by subtracting $29.1 \mathrm{ft}$ from the stage at the Nora streamgage. This computation was completed by the Perl scripts, and the result was passed to the $\mathrm{C}++$ scripts. Thus, the output from the CGNS input service for the FaSTMECH model contained the streamflow and associated stage at the downstream model extent. 
- Hydraulic modeling service.-This Web service (called the "FaSTMECH execution service" by the interagency team) was developed to automatically run the calibrated FaSTMECH model to create the static floodinundation maps described in the "Development of a Static Flood-Inundation Map Library" section of this report. The CGNS input service generated an input file containing the boundary conditions necessary to run the hydraulic model and, for each model run, generated flood-depth raster data files. These files were then passed as input files to a CGNS output service.

- CGNS output service.-The CGNS output service processed the FaSTMECH output from the Hydraulic modeling service (flood-depth raster data files) into a format that was usable by a property-loss estimation service and passed the files to that service.

- Parcel building point and property value data services.-These services supplied building point (centroid) locations and assessed structure and content value to the Property loss estimation service. Building location data were from IMAGIS dataset, and assessed structure and content value were from the CAMA dataset discussed in the "Flood-Loss Estimate" section of this report.

- Property loss estimation service.-This service accepted outputs from the CGNS output service and the Parcel building point and property value data services, selected the flooded buildings, and calculated the monetary damage to the building and contents using Federal Insurance Agency (FIA) depth-damage functions. The FIA functions are curves that plot flood depths against percent damages for a variety of building types and occupancies; similar functions also are used in HAZUS-MH program to calculate flood damages. The percent property damages from the FIA curves were used with the assessed structure and content value to calculate total flood-damage loss values. These values were passed to the Web map e-service.

- Web map e-service.-This service produced the end product of the dynamic SOA application. The service assembled and outputted - for each flood image generated by the dynamic application - the flood-inundation map (extent and depth) and flooded building locations through a Web GUI (fig. 9). The GUI allowed a user to display the flood-inundation surface and building locations over satellite photography images or mapped streets. The service also provided the flood-damage estimates for each flood map in a menu format through the Web GUI (fig. 9).
In summary, the dynamic application was designed to automatically activate when the predetermined streamflow of $11,000 \mathrm{ft}^{3} / \mathrm{s}$ was attained at the Nora streamgage/flood forecast point. The application, once activated, would generate floodinundation maps served through the GUI that were based on the most recent observed data and the most up-to-date NWS flood forecast data. If the flood forecast changed (because of changes in stage and streamflow predictions or changes in duration), the application would display the updated stages and streamflows and would show updated flood-inundation maps through the GUI. The application was intended to display an inundation map for each stage/streamflow in the flood forecast. Flood forecasts for the Nora streamgage were to stay active from the current day through 5 days out from the current day. Forecast stages and streamflows were to be available for 1-hour intervals during the forecast period. When the current streamflow dropped below $11,000 \mathrm{ft}^{3} / \mathrm{s}$, the application's active mode would be terminated. The application would then remain in a quiescent mode but automatically monitor the AHPS Web service hourly; as long as the streamflow was below $11,000 \mathrm{ft}^{3} / \mathrm{s}$ the application would remain in the quiescent mode (fig. 10).

The dynamic application was put into service in June 2009 and has been tested twice since that time. For the first test, a flood was simulated by manually creating XML AHPS flood forecast data for the Nora streamgage/flood forecast point, obtained from the NWS from an actual previous flood, and making those data available to the dynamic application CGNS input service. The application performed as expected; figure 9 shows one of the flood-inundation maps that resulted from the test.

The second test was an actual flood in March 2010. When the streamflow at the Nora streamgage reached 11,000 $\mathrm{ft}^{3} / \mathrm{s}$, the dynamic application activated without intervention and began to output flood-inundation maps. The application generated a number of inundation maps that were incorrect: the stage and streamflow boundary conditions used to generate the erroneous maps did not match the AHPS flood forecast information that was provided to the application by the CGNS input service. After this flood, a diagnostic effort revealed that the application had not deactivated and gone into the quiescent mode when the streamflow had dropped below $11,000 \mathrm{ft}^{3} / \mathrm{s}$. Rather, the application ran the FaSTMECH model for lower flows that it was not calibrated to run; the model could not converge on a solution for those lower flows. The model then, in an attempt to converge on a correct solution, kept iteratively running with different boundary conditions that did not match the actual AHPS input. In July 2010, new scripts were put into place that corrected this error. The scripts were incorporated into the application and it was placed back into a running quiescent mode, awaiting the next actual event to trigger a new test. 

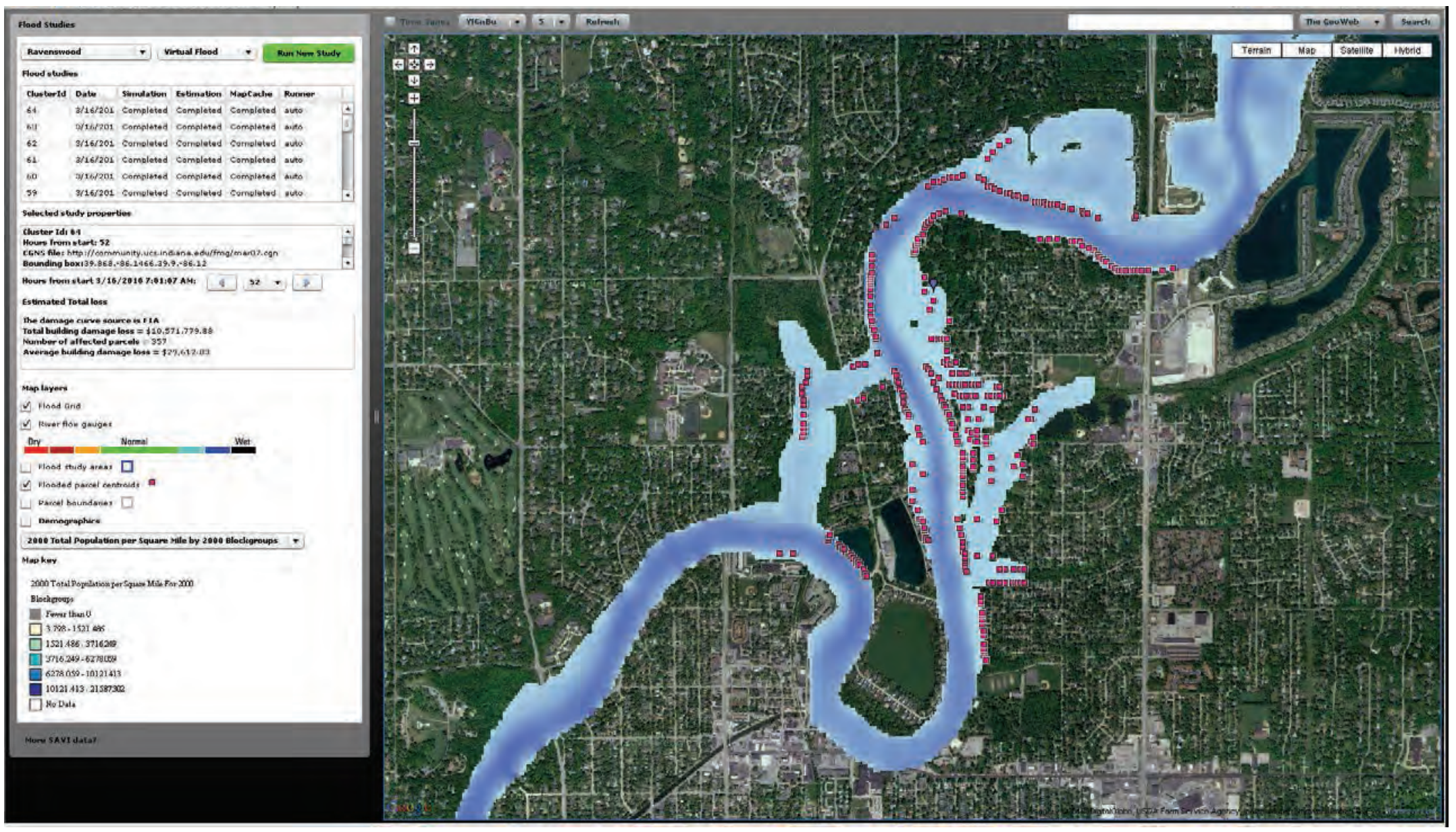

Figure 9. Example screenshot from the dynamic flood-mapping application. 


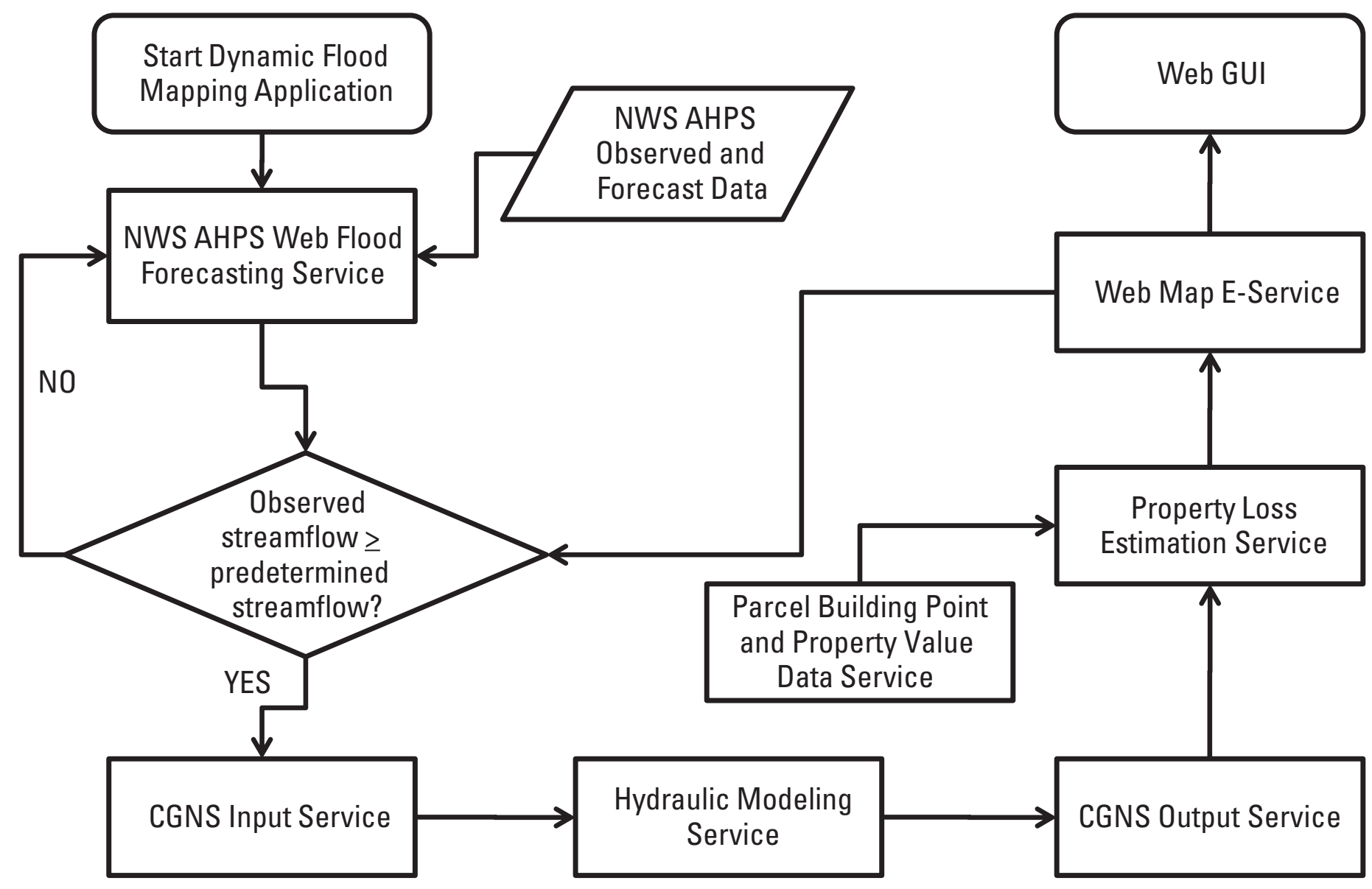

Figure 10. Simplified flowchart for the dynamic flood-mapping application. 


\section{Dynamic Application Limitations and Future Needs}

The interagency team and the Indiana Silver Jackets larger team deemed the dynamic application to be a success in that it met the predetermined requirements. The application activated without operator intervention, and it produced floodinundation map and loss estimates that could be accessed through the Web GUI. The application does have limitations that will need to be addressed in the future. Regarding the potential use for other stream reaches, the largest limitation is that the FaSTMECH model did not offer advantages in terms of dynamic hydrologic response over the static map libraries. The model, for example, did not account for varying tributary responses during a flood, because the model accepted only one set of boundary conditions per study reach - there was no provision for changing a discharge mid-reach. The model, in reality, will output flood-inundation maps that are identical to the static maps for the same set of boundary conditions. The application should produce reliable results for a large mainstem flood on the White River; however, for a reach with major tributaries there would need to be a significant change in modeling - such as the incorporation of multiple FaSTMECH models, or the introduction of alternative models - along with additional data sources for near-real-time/forecast tributary streamflows in order to have a true dynamic response to different flood events.

Another limitation involved physical changes in the model reach that were not accounted for by the model, such as the formation of debris or ice jams on structures or a breach in a levee. For a true hydrologic response, methods will need to be investigated in the future to account for these and other physical changes in the system.

There were also limitations in the end product of this application - the service and associated GUI that provided the flood-inundation maps and flood-loss estimates to users. One limitation was that the GUI showed actual addresses for buildings that were flooded; because of this privacy issue, the GUI was not releasable to the public. It is viewable only by the interagency team at the present. Another major limitation was how potential error information was conveyed to nontechnical users of the GUI: disclaimers about data accuracy and the presentation of that accuracy will need to be addressed before the application can be widely released.

Addressing these and other limitations showed the advantage of building the dynamic application by using an SOA infrastructure. The infrastructure allowed for the modification of existing services and the addition of new services without changing all services. For example, a new 2D hydraulic model could be incorporated into the Hydraulic modeling service that would accept multiple changes in discharge for a model reach. The CGNS input and output services could be modified to meet the input/output needs of the new model, but all other services including the Web map e-service would likely not require modification. Thus, the end product — maps and flood estimates served through the GUI-would have a similar appearance to a user after the new model was incorporated, and the underlying change in the hydraulic model would be transparent to the user.

Conversely, the Web map e-service could be modified substantially with little modification to the other services that serve it with data and information. For example, the service could be modified to allow different levels of access through the GUI to overcome the address privacy issue, whereby emergency responders could have access to individual address information but the general public would not. That modification need not affect the services that generate the flood-inundation maps and associated flood-loss estimates.

Building on the successful effort of the pilot project, and the lessons learned from that effort, the Indiana Silver Jackets member agencies will continue to investigate ways to improve the dynamic application and will position the application for wider use in the future. In the interim, the flood-inundation maps for the study reach will be widely available as static map libraries served through the Internet.

\section{Summary and Conclusions}

The Indiana Silver Jackets hazard mitigation taskforce fostered a pilot project to develop near-real-time and forecast flood-inundation mapping products for an 11-mile reach of the White River in Indianapolis. The pilot project had three components: (1) creation of a static flood-inundation map library, (2) demonstration of the utility of project products for use in a flood-loss estimation GIS application, and (3) development of a dynamic, near real-time flood-inundation mapping application.

For the first component, a 2D hydraulic model called FaSTMECH was developed and calibrated for the model reach by using high-water mark and USGS streamgage data. The model was used to create a static flood-inundation map library. The inundation maps from the library are served through the Internet in GIS, KML, and PDF formats.

The second component involved demonstrating the use of a flood-inundation map from the map library (for the Ravenswood neighborhood within the study reach) and FEMA's HAZUS-MH application to obtain a flood-loss estimate. The HAZUS-MH level 2 analysis was done by using an inundation map for a stage of $17 \mathrm{ft}$ and detailed local information on buildings' location and value.

The third component of the pilot study was development of a dynamic flood mapping application that, using near real-time USGS streamgage data and NWS flood forecast data, would automatically run a hydraulic model and produce floodinundation maps during flood events. This component resulted in a composite application that integrated multiple, independent Web services to generate the flood-inundation maps and used those data to estimate flood-related property losses. 
The surface-water modeling successfully accomplished two important objectives. First, it predicted flooded areas at multiple selected river stages; the results should be used with the understanding that the predicted flooded areas have a potential "error band," as explained in the section on model limitations. Second, the modeling also revealed what processes in surface-water flow were important to simulate in a real-world situation, such as flow over low-head dams. Results from this study helped to (1) determine the appropriate field data to collect and (2) guide the selection of more appropriate models for use in future model studies of urban environments.

The flood-loss estimate component of the study showed the usefulness of using the flood-inundation map libraries in conjunction with detailed local building information to quickly generate flood-loss estimates with HAZUS-MH. The floodinundation map library GIS files were in a format convenient for importing maps directly into HAZUS-MH to complete a level 2 analysis.

The dynamic application has shown that it is technically feasible to automatically run a hydraulic model during a flood event based upon near-real-time and forecast stream data, to produce observed and forecast flood-inundation maps from the model, to assimilate the mapping data and flood-damage information, and to provide the maps and flood-damage information through a Web GUI. Users of the application, such as emergency managers, need not have extensive technical expertise in hydrology or flood-damage estimates to use the tool during flood events.

\section{References Cited}

Barry and Associates [2010], Service-oriented architecture (SOA) definition, accessed September 23, 2010, at http://www.service-architecture.com/web-services/articles/ service-oriented_architecture_soa_definition.html.

Barton, G.J., McDonald, R.R., Nelson, J.M., and Dinehart, R.L., 2005, Simulation of flow and sediment mobility using a multidimensional flow model for the white sturgeon critical-habitat reach, Kootenai River near Bonners Ferry, Idaho: U.S. Geological Survey Scientific Investigations Report 2005-5230, 54 p.

Berenbrock, Charles, and Tranmer, A.W., 2008, Simulation of flow, sediment transport, and sediment mobility of the Lower Coeur d'Alene River, Idaho: U.S. Geological Survey Scientific Investigations Report 2008-5093, 164 p.

Boston University [2009], Scientific computing and visualization, Introduction to image files tutorial, Raster image files, accessed June 30, 2009, at http://scv.bu.edu/documentation/ tutorials/ImageFiles/image101.html.
BusinessDictionary.com [2010], Markup language, accessed September 23, 2010, at http://www.businessdictionary.com/ definition/markup-language.html.

Chow, V.T., 1959, Open-channel hydraulics: New York, McGraw-Hill Book Company, 680 p.

Conaway, J.S., and Moran, E.H., 2004, Development and calibration of a two-dimensional hydrodynamic model of the Tanana River near Tok, Alaska: U.S. Geological Survey Open-File Report 2004-1225, 13 p.

Day, H.J. 1970, Flood warning benefit evaluation-Susquehanna River Basin (urban residences): Silver Spring, Md., National Weather Service, ESSA Technical Memorandum WBTM Hydro 10.

Federal Emergency Management Agency, 2009a, Federal Disaster Declarations, accessed January 15, 2009, at http://www.fema.gov/news/disasters.fema.

Federal Emergency Management Agency, 2009b, HAZUSMH analysis levels, accessed June 29, 2009, at http://www.fema.gov/plan/prevent/hazus/hz_levels.shtm.

Federal Emergency Management Agency, 2009c, HAZUS-MH overview, accessed June 29, 2009, at http://www.fema.gov/ plan/prevent/hazus/hz_overview.shtm.

Harbaugh, A.W., Banta, E.R., Hill, M.C., and McDonald, M.G., 2000, MODFLOW-2000, the U.S. Geological Survey modular ground-water model-User guide to modularization concepts and the ground-water flow process: U.S. Geological Survey Open-File Report 00-92, 121 p.

Indiana Spatial Data Portal, 2005 IndianaMap natural color orthophotography, accessed July 17, 2008, at http://www.indiana.edu/ gisdata/statewide/05nc.html.

Kenney,T.A., 2005, Initial-phase investigation of multi-dimensional streamflow simulations in the Colorado River, Moab Valley, Grand County, Utah, 2004: U.S. Geological Survey Scientific Investigations Report 2005-5022, 69 p.

McDonald, R.R., Bennett, J.P., and Nelson, J.M., 2001, The USGS multi-dimensional surface water modeling system, in Proceedings of the Seventh Interagency Sedimentation Conference, Reno, Nev., March 25-29, 2001: v. 1, p. I-161-I-167.

McDonald, R.R., Nelson, J.M., and Bennett, J.P. [2005], Multi-dimensional surface-water modeling system user's guide: U.S. Geological Survey online documentation, accessed August 5, 2011, at http://wwwbrr.cr.usgs.gov/ projects/GEOMORPH_Lab/WebHelp_Pro/MD_SWMS.htm. 
McDonald, R.R., Nelson, J.M., Kinzel, P.J., and Conaway, J.S., 2005, Modeling surface-water flow and sediment mobility with the multi-dimensional surface-water modeling system (MD_SWMS): U.S. Geological Survey Fact Sheet 2005-3078, 6 p.

Muthukumar, Subrahmanyam, 2005, Riverine flood modeling in HAZUS-MH-Overview of the implementation, in Proceedings of the 2005 Georgia Water Resources Conference, University of Georgia, April 25-27, 2005: 4 p.

National Hydrologic Warning Council, 2006, Flood management benefits of USGS streamgaging program: Sacramento, Calif., prepared by David Ford Consulting Engineers, 48 p.

National Weather Service, 2008, Guide to hydrologic information on the Web: 6 p.

Nelson, J.M., Bennett, J.P., and Wiele, S.M., 2003, Flow and sediment-transport modeling, in Kondolf, G.M., and Piégay, Hervé, eds., Tools in fluvial geomorphology: Hoboken, N.J., Wiley, p. 539-576.

National Oceanic and Atmospheric Administration, 2009, Quality Assurance and Quality Control Plan for flood inundation mapping at river forecast locations for the National Weather Service Advanced Hydrologic Prediction Service: Cary, N.C., prepared by Watershed Concepts, AECOM Water, 97 p.

Pielke, R.A., Jr., Downton, M.W., and Barnard Miller, J.Z., 2002, Flood damage in the United States, 1926-2000-A reanalysis of National Weather Service estimates: Boulder, Colo., University Corporation for Atmospheric Research, 86 p., accessed January 15, 2009, at http://www.flooddamagedata.org/full_report.html.

Polis Center, 2008, Ravenswood HAZUS-MH flood analysis final report, Version 1.0: Indianapolis, Ind., 27 p.
Polis Center, 2009, Geospatial Service-Oriented Architecture for flood inundation mapping and hazard assessment, final report: Indianapolis, Ind., 22 p.

Rantz, S.E., and others, 1982, Measurement and computation of streamflow-Volume 1, Measurement of stage and discharge, and volume 2, Computation of discharge: U.S. Geological Survey Water-Supply Paper 2175, 631 p.

Simões, F.J.M., and McDonald, R.R., 2004, A modeling system for 2D flow in surface waters, in Altinakar, M.A., and others, eds., Advances in hydro-science and engineering-Proceedings of the 6th International Conference on Hydro-Science and Engineering, Brisbane, Australia, May 31-June 3, 2004: v. 6.

Temple University, Social Science Data Library, 2003, Census geography, accessed August 27, 2010, at http://www.temple. edu/ssdl/census geography.htm.

U.S. Army Corps of Engineers, 1983, Flood insurance study, City of Indianapolis, Indiana, Marion County: 67 p.

U.S. Department of Transportation, Federal Highway Administration, 2009, Tidal hydrology, hydraulics, and scour at bridges: Hydraulic Engineering Circular 25, chap. 4, accessed June 16, 2009, at http://www.fhwa.dot.gov/ engineering/hydraulics/hydrology/hec25c4.cfm.

U.S. Geological Survey, 2006, Flood hazards-A national threat: U.S. Geological Survey Fact Sheet 2006-3026, 2 p.

W3schools [2010], Introduction to XML, accessed September 23, 2010, at http://www.w3schools.com/XML/ xml_whatis.asp. 


\section{Glossary}

bed shear stress Stress that acts in the direction of flow on the streambed. Bed shear stress is often related to the ability of flow to move sediment on the streambed.

datum A surface or point relative to which measurements of height and (or) horizontal position are reported. A vertical datum is a horizontal surface used as the zero point for measurements of gage height, stage, or elevation; a horizontal datum is a reference for positions given in terms of latitudelongitude, State Plane coordinates, or Universal Transverse Mercator (UTM) coordinates.

depth-damage curve Depth-damage curves relate damage as percentage of replacement cost against effective flood depths; effective flood depths are quantified as the height of flood waters above the first floor.

drainage area The drainage area of a stream at a specified location is that area, measured in a horizontal plane, which is enclosed by a drainage divide.

flood peak The highest value of the stage or discharge attained by a flood; thus, peak stage or peak discharge. Flood crest has nearly the same meaning, but since it connotes the top of the flood wave, it is properly used only in referring to stage - thus, crest stage, but not crest discharge.

flood plain A strip of relatively smooth land bordering a stream, built of sediment carried by the stream and dropped in the slack water beyond the influence of the swiftest current. It is called a living flood plain if it is overflowed in times of high water, but a fossil flood plain if it is beyond the reach of the highest flood. gage height The water-surface elevation referred to some arbitrary gage datum. Gage height is often used interchangeably with the more general term stage although gage height is more appropriate when used with a reading on a gage.

stage The height of a water surface above gage datum; same as gage height.

steady flow A condition in which discharge and depth of flow does not change with time or during a selected period of time.

stream A general term for a body of flowing water. In hydrology the term is generally applied to the water flowing in a natural channel as distinct from a canal.

streamflow The discharge that occurs in a natural channel. Although the term discharge can be applied to the flow of a canal, the word streamflow uniquely describes the discharge in a surface stream course.

streamgage A gaging station where a record of discharge of a stream is obtained. Within the U.S. Geological Survey this term is used only for those gaging stations where a continuous record of gage-height is obtained.

thalweg The line formed by connecting points of minimum streambed elevation (deepest part of the channel).

transient flow A condition in which discharge and depth of flow changes with time. 



\section{Appendix 1. Static inundation maps for White River at Indianapolis Museum of Art, Indiana (Virginia B. Fairbanks Art and Nature Park)}

DISCLAIMER: Flood-inundation area boundaries and depths are intended to show the approximate extents and depths of floods, with aerial photography used as a base map. Error sources in these boundaries can include, but are not limited to, digital-elevation-data errors and hydraulic modeling errors. Errors can result in inaccuracies in flood extent and depth; thus, the flood-inundation area boundaries and depth depicted here should be considered estimates. 


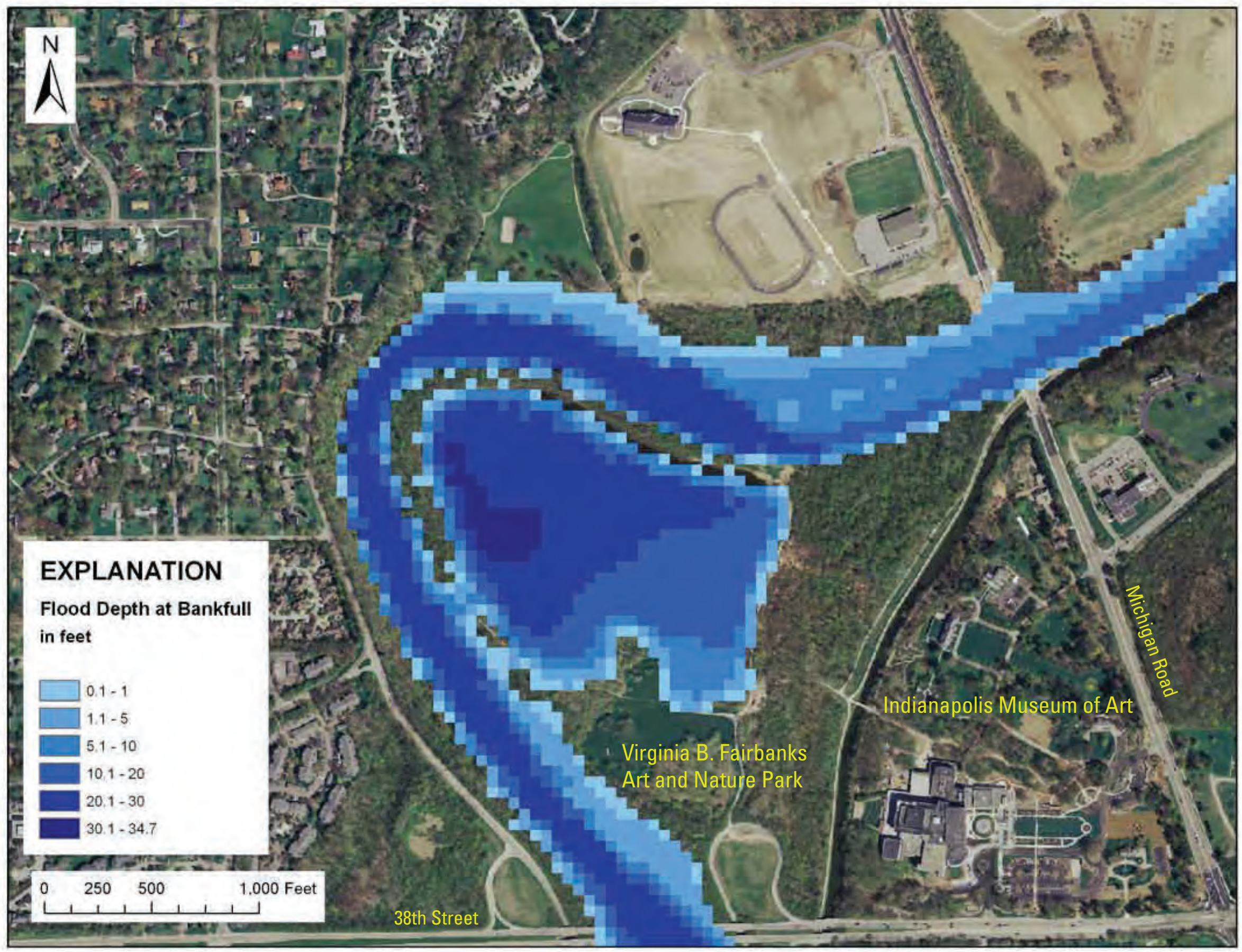




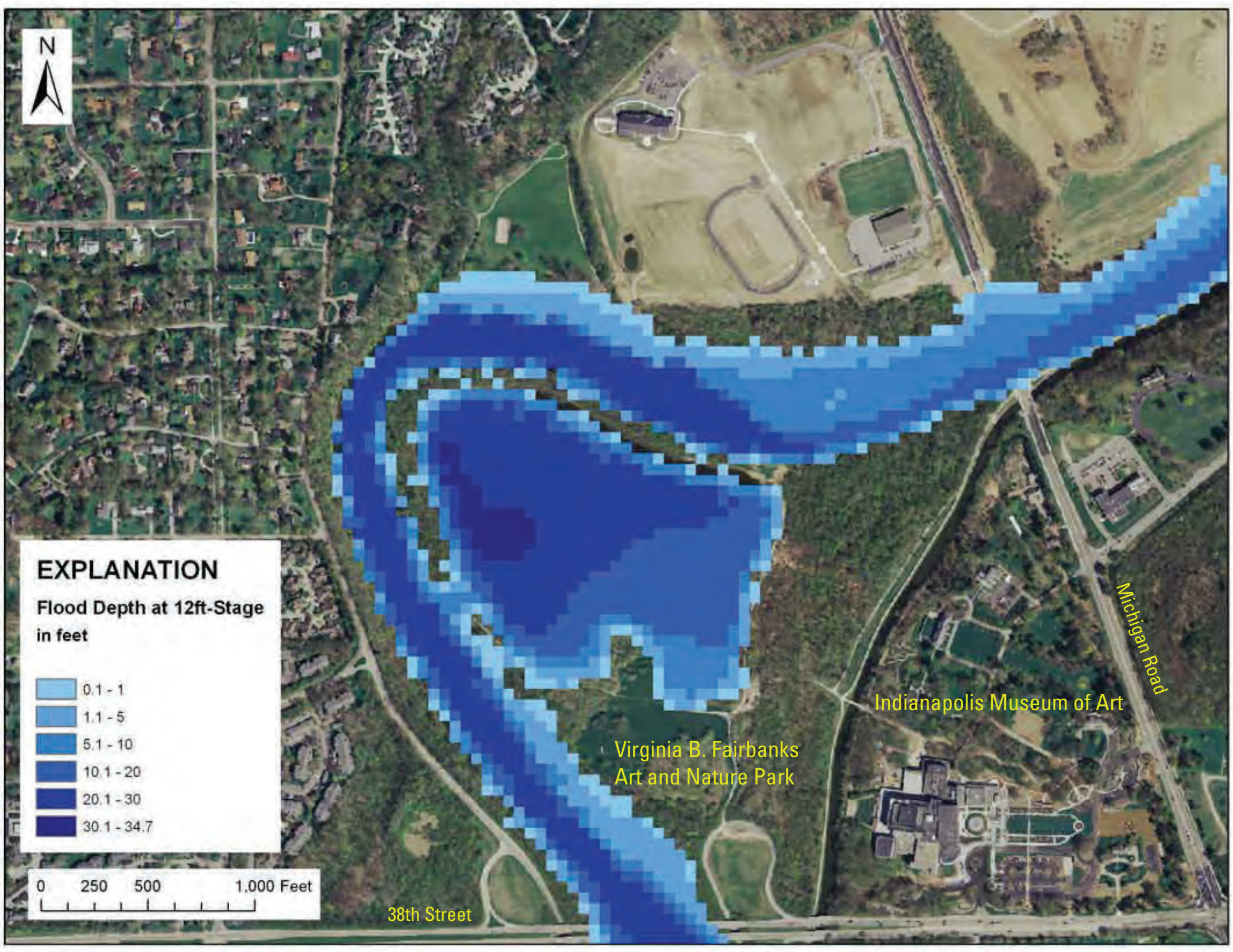




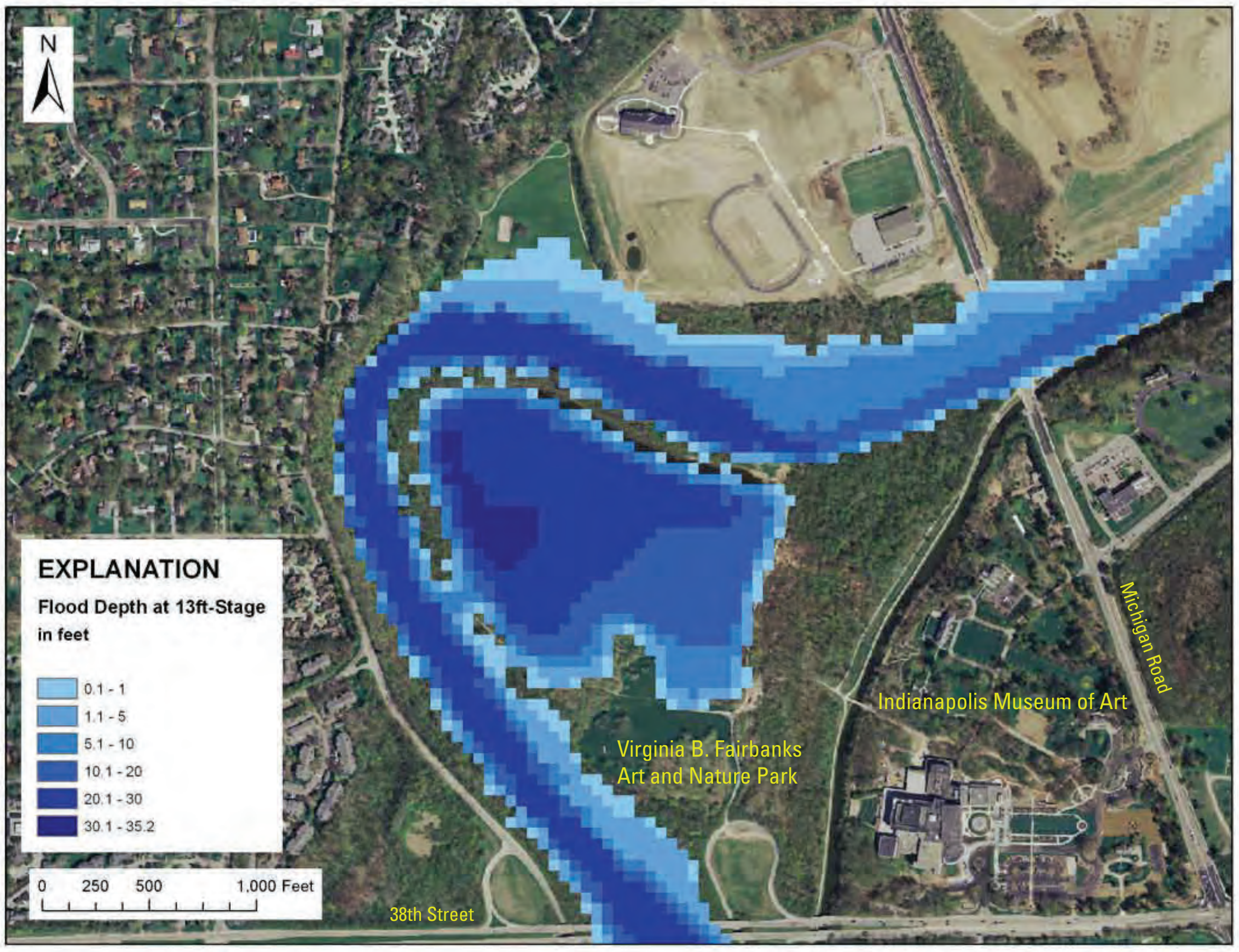




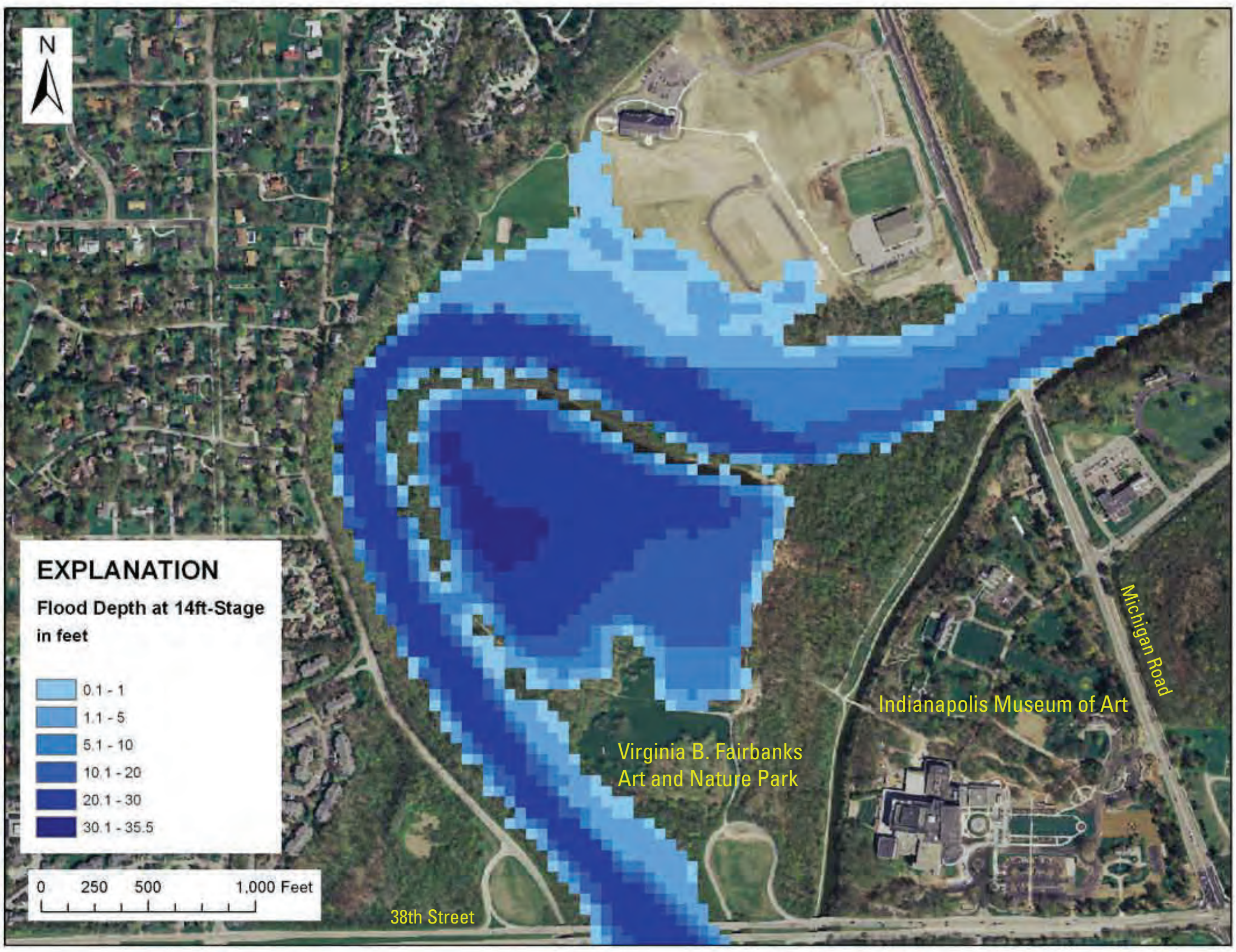




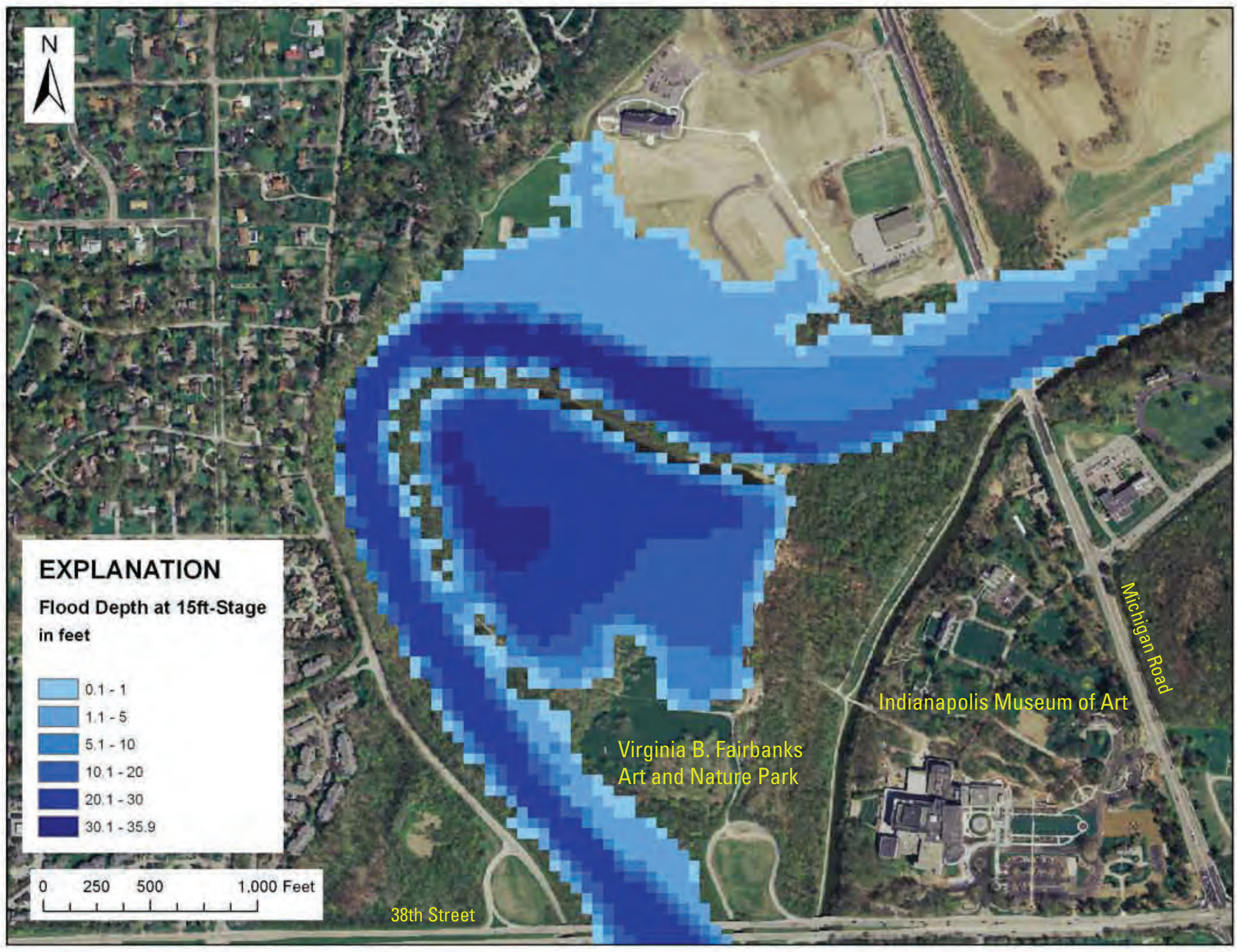




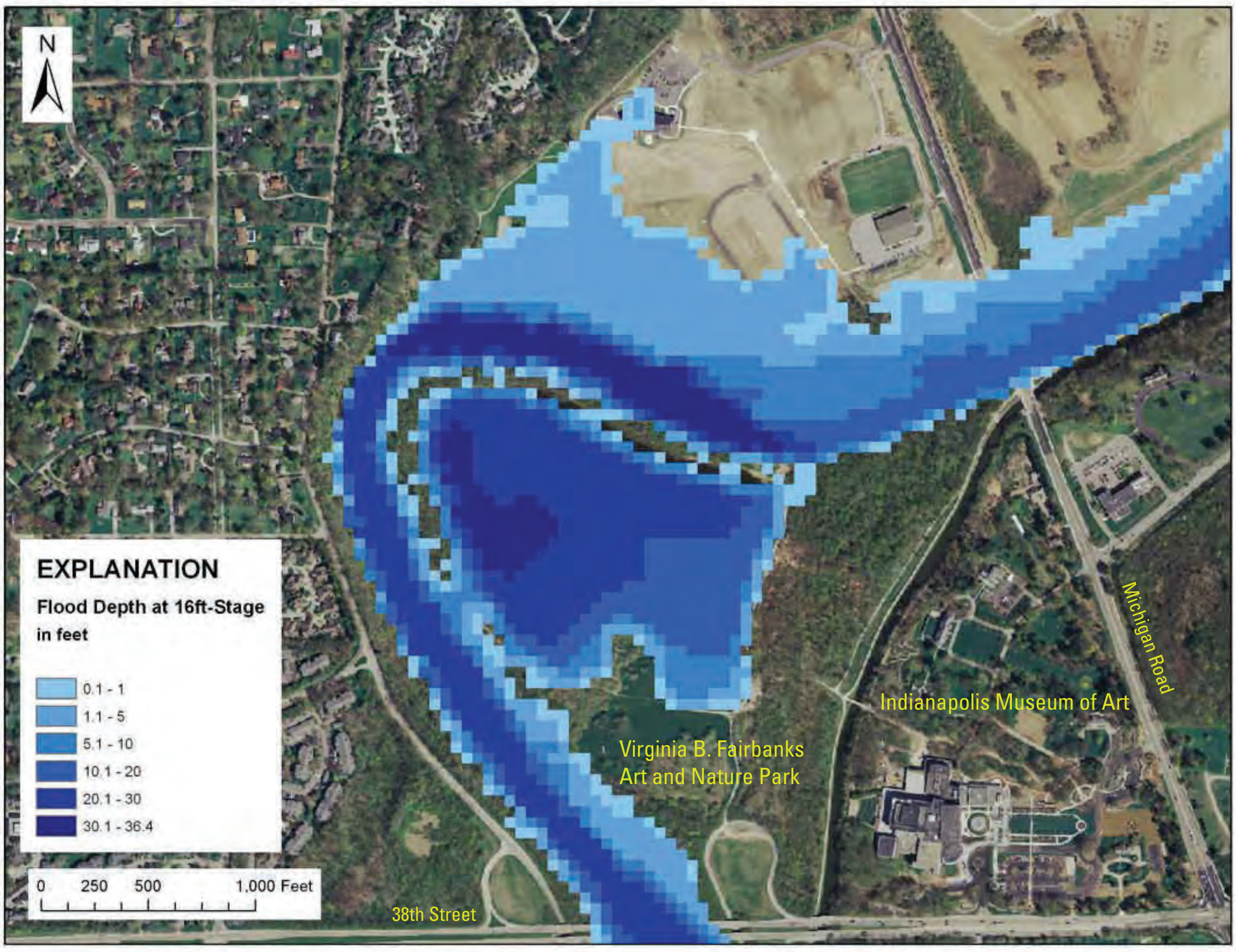




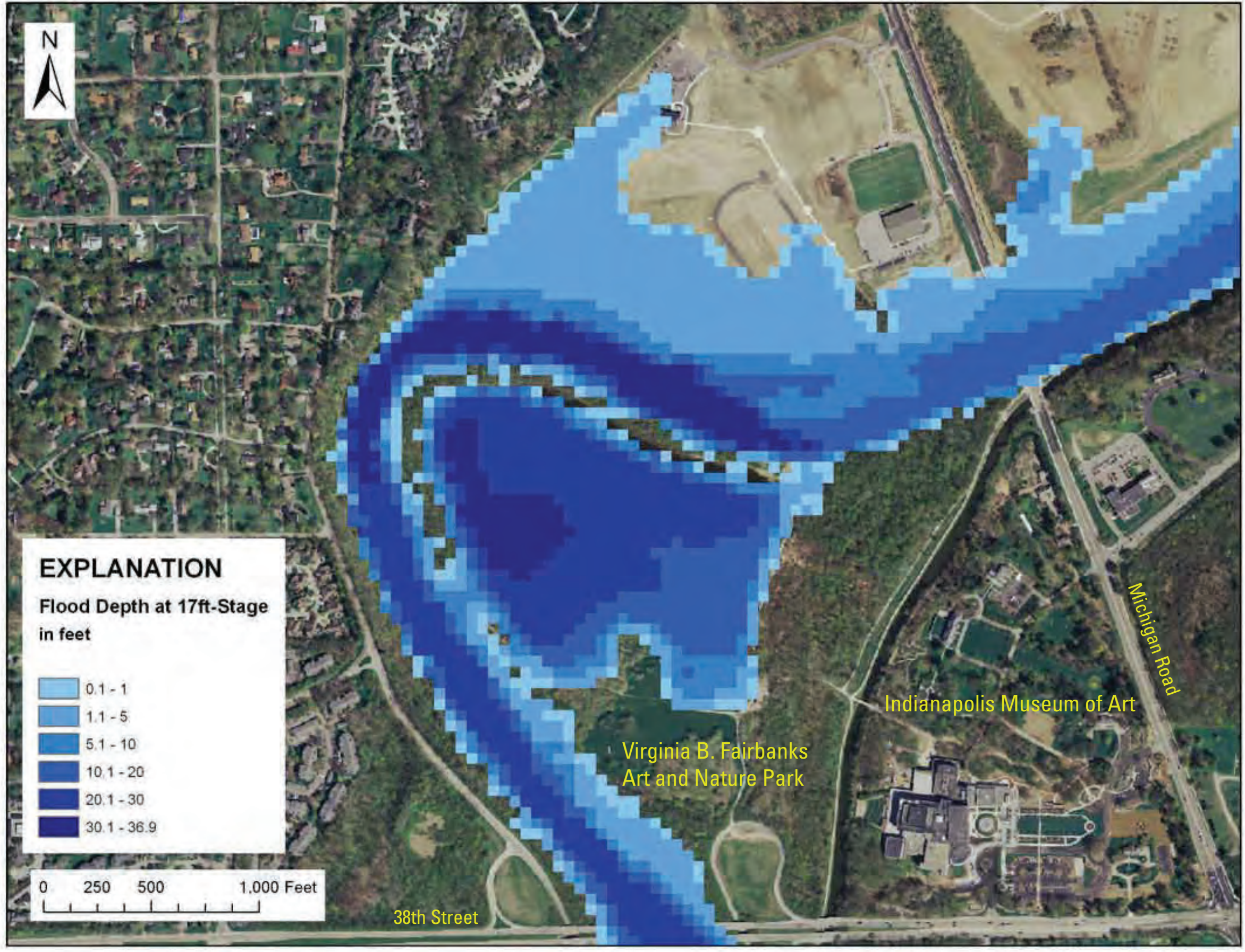




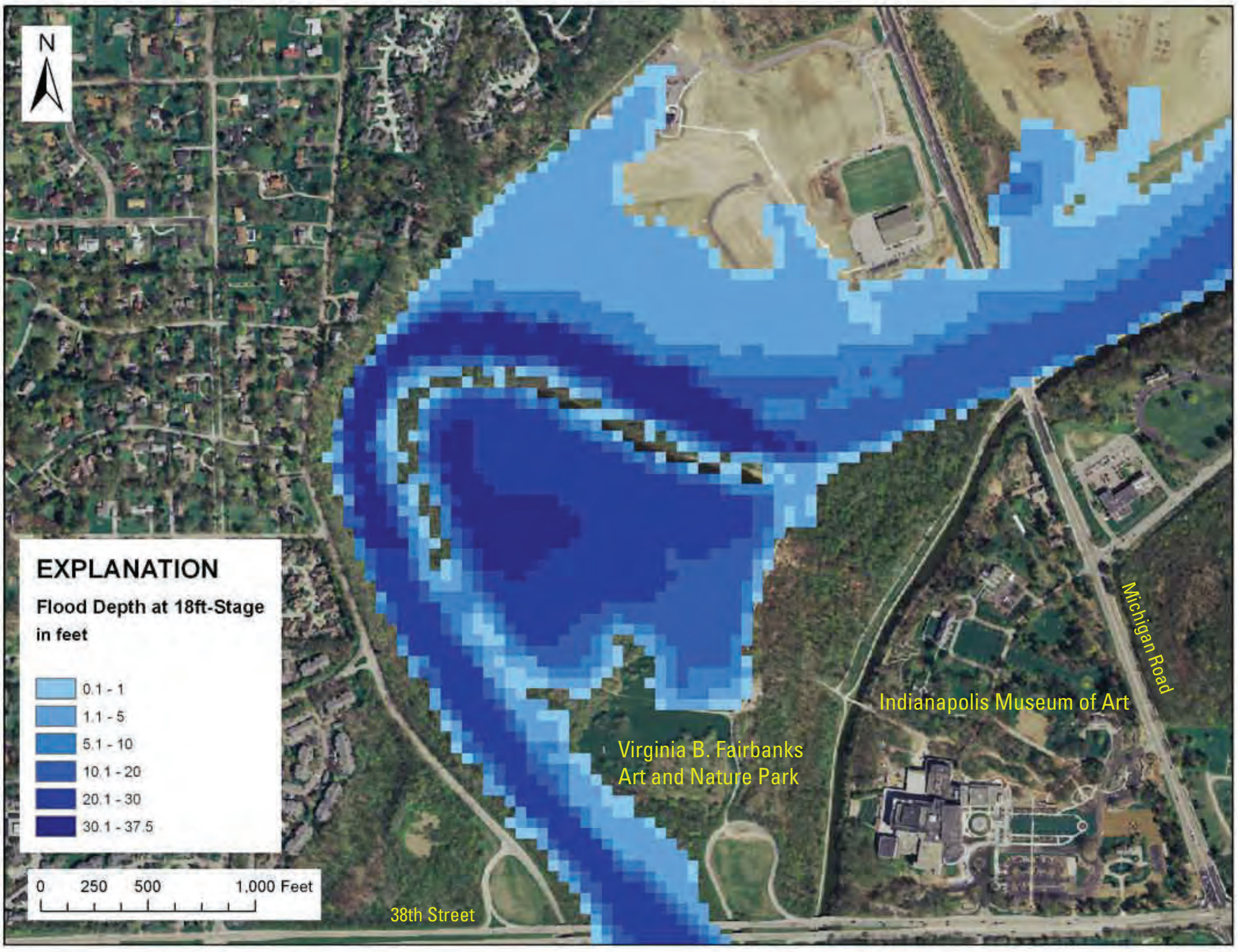




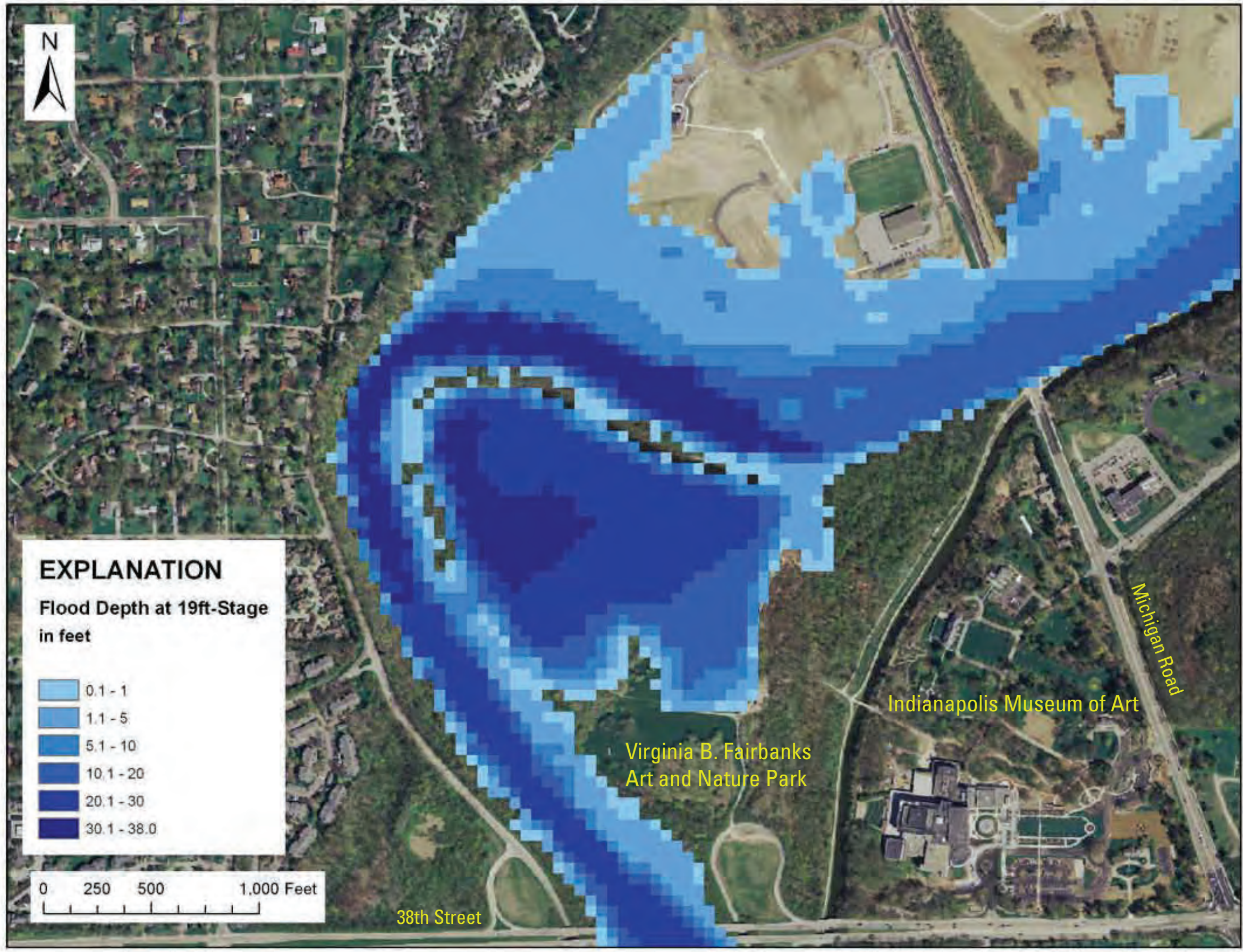




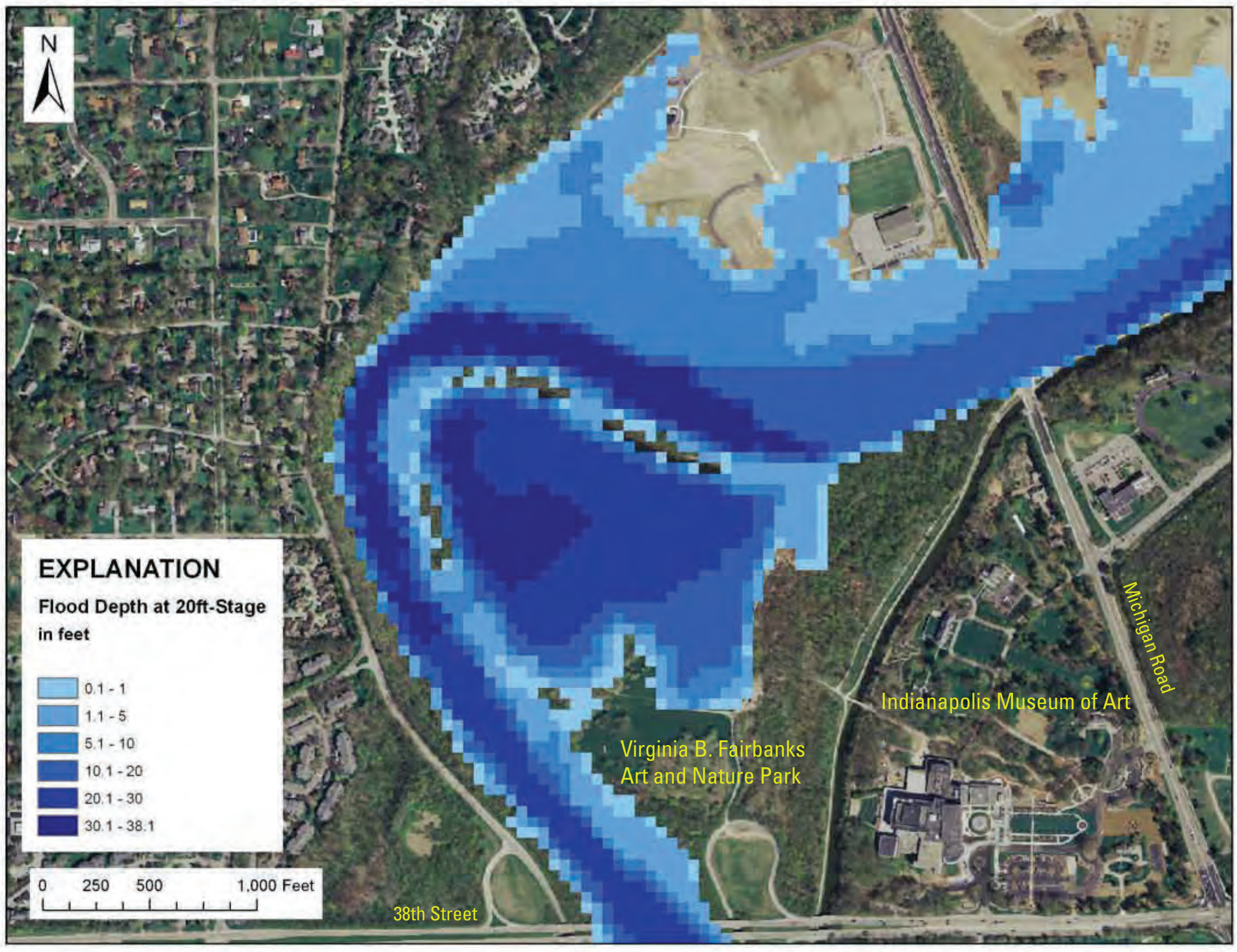




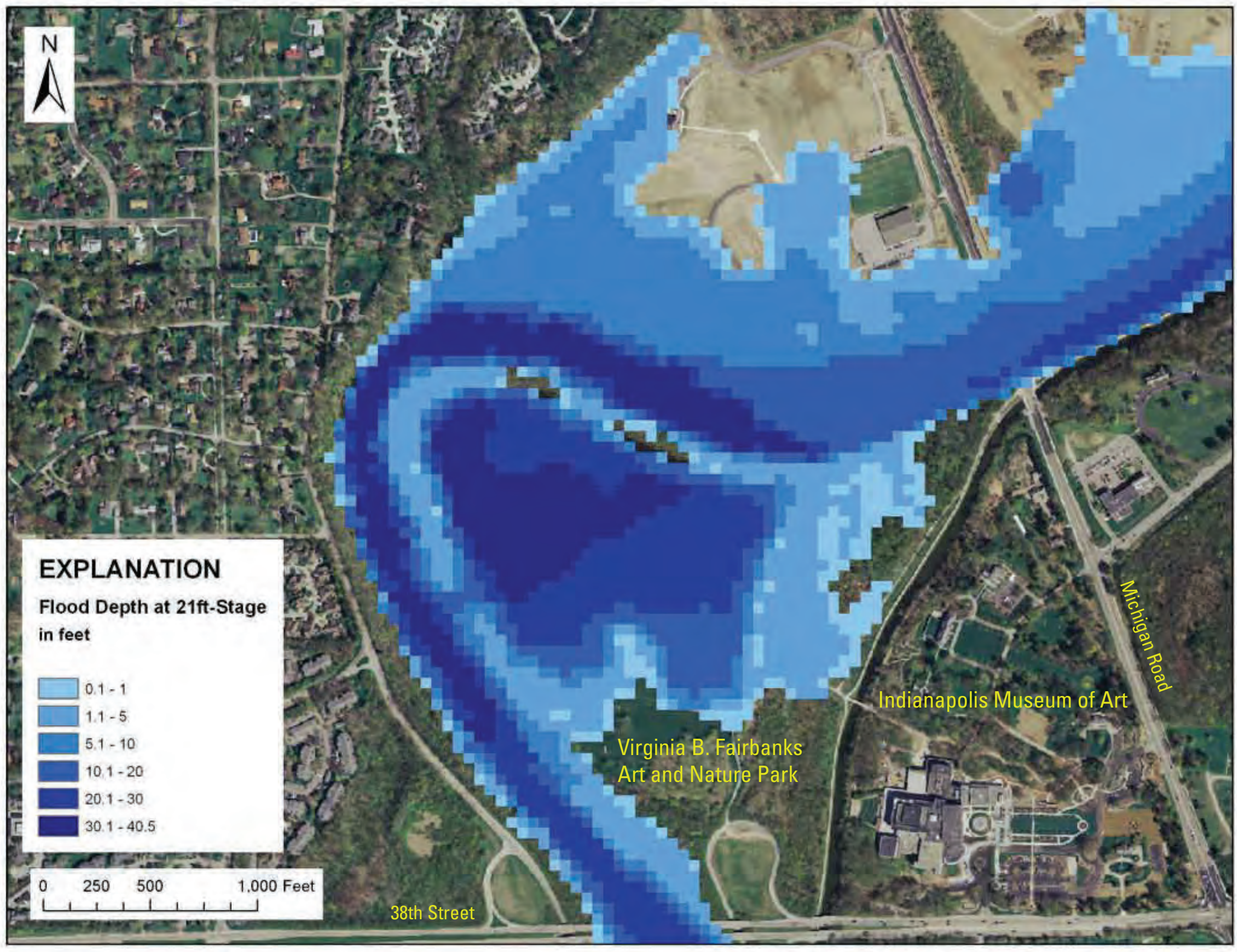




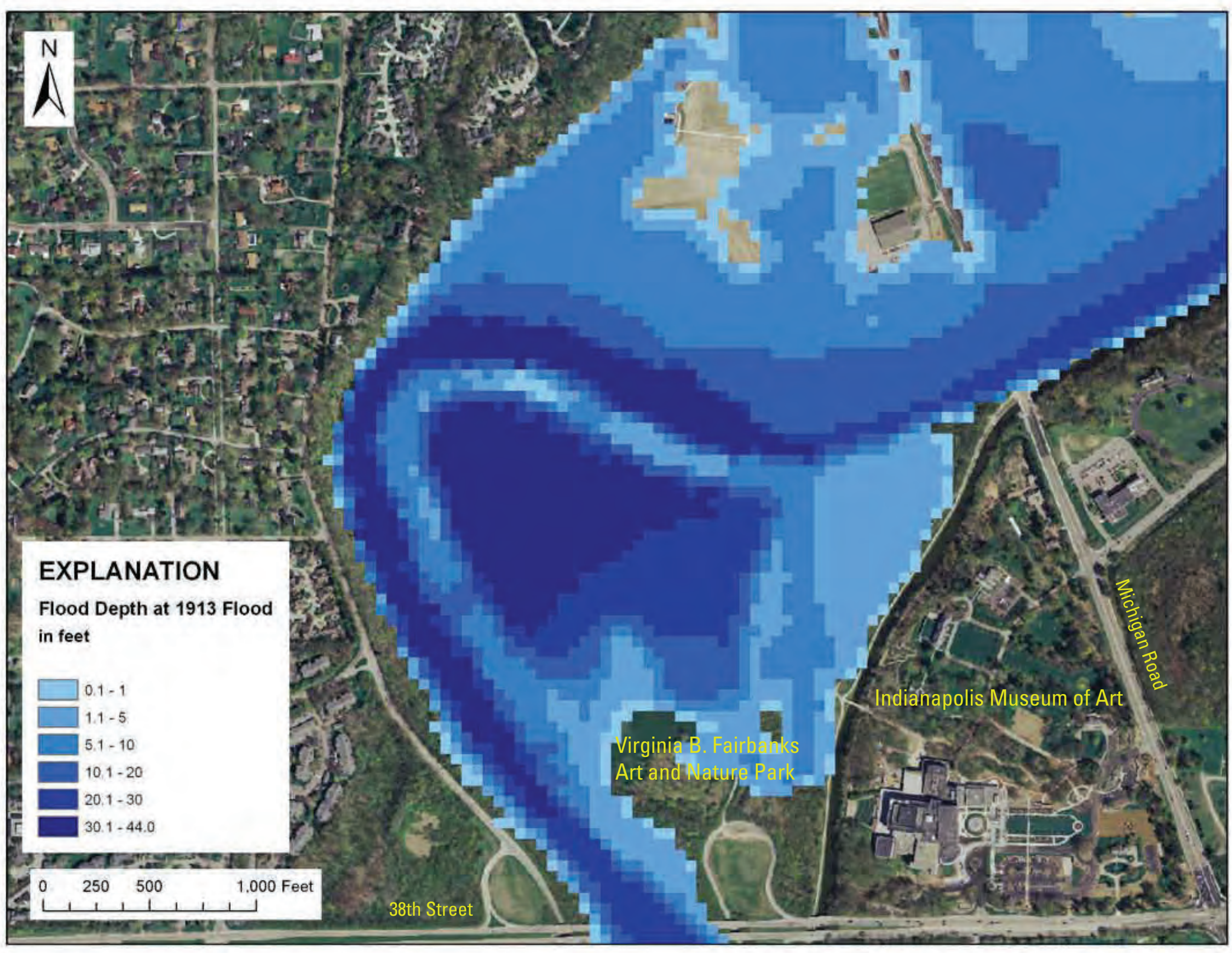





\section{Appendix 2. Static inundation maps for White River near Nora, Indiana}

Additional files, including high-resolution PDF files, KML files and GIS data files, are available from the following Web link: http://water.usgs.gov/osw/flood_inundation/projects/fimi/.

DISCLAIMER: Flood-inundation area boundaries are intended to show the approximate extents of floods, with aerial photography used as a base map. Error sources in these boundaries can include, but are not limited to, digital-elevation-data errors and hydraulic modeling errors. Errors can result in inaccuracies in flood extent; thus, the flood-inundation area boundaries depicted here should be considered estimates. 
U.S. DEPARTMENT OF THE INTERIOR

U.S. GEOLOGICAL SURVEY

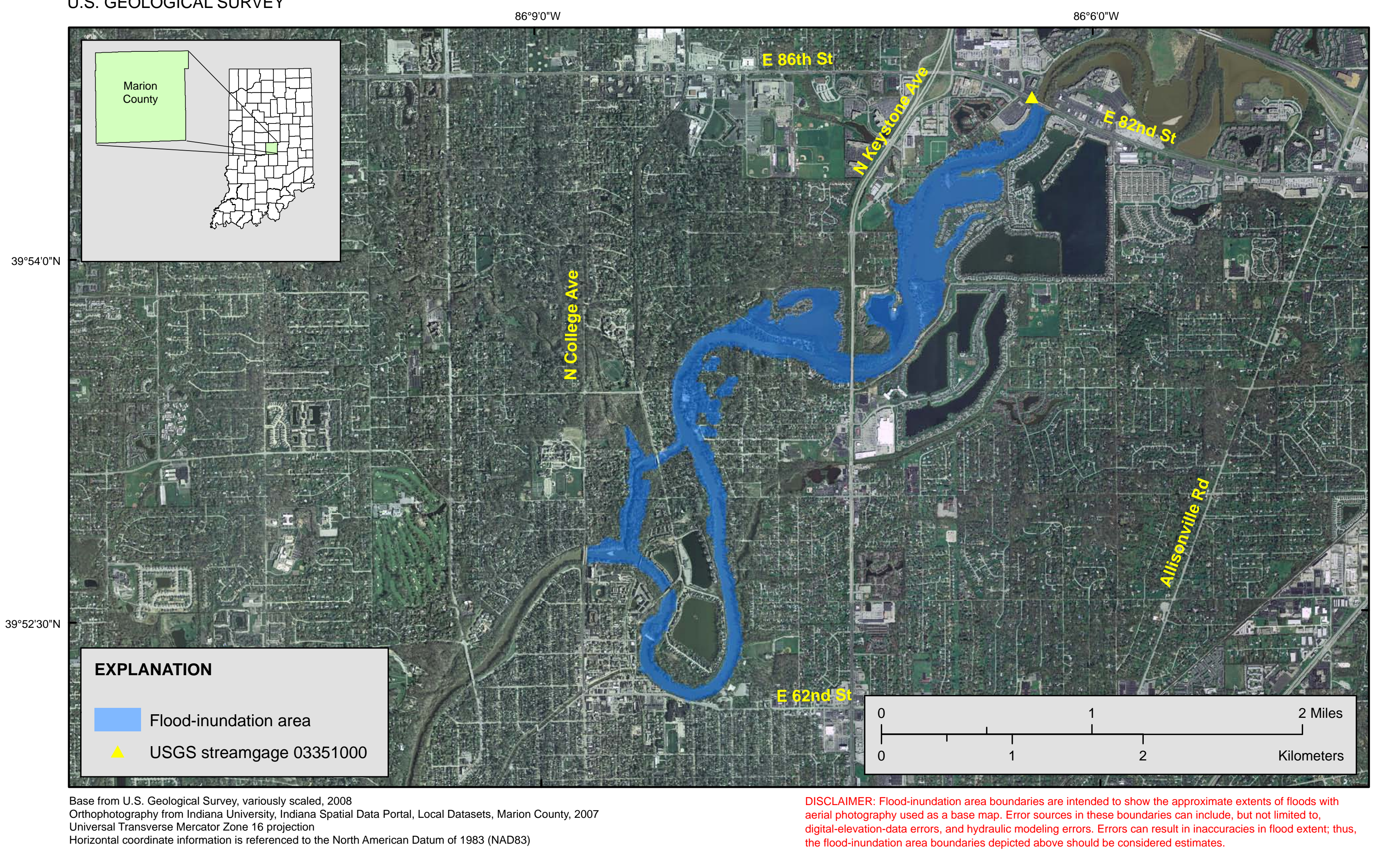

Flood-inundation areas for White River near Nora, Indiana (station 03351000), stage of 11.0 feet, 721.5 feet NAVD88. 
U.S. DEPARTMENT OF THE INTERIOR

U.S. GEOLOGICAL SURVEY

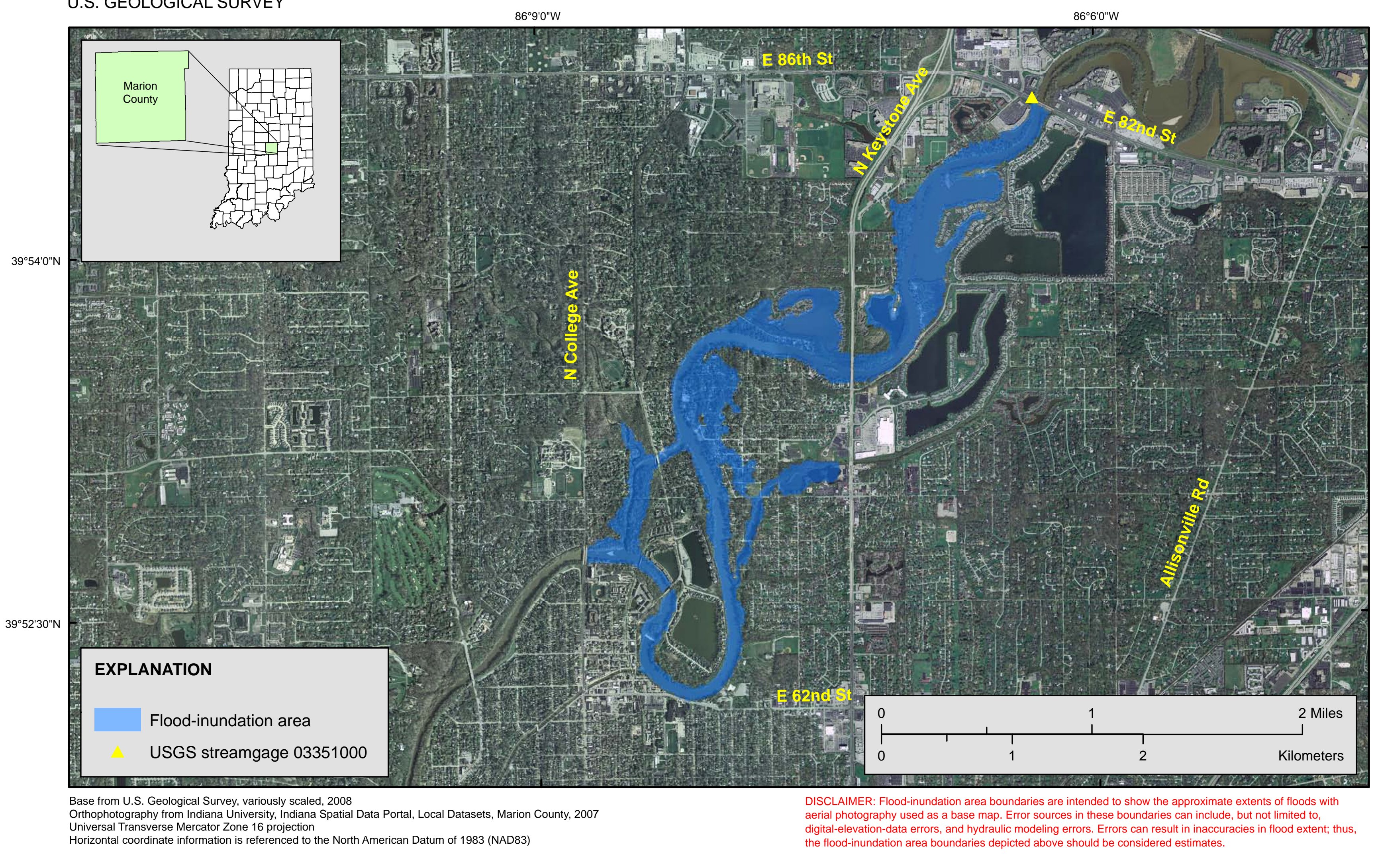

Flood-inundation areas for White River near Nora, Indiana (station 03351000), stage of 12.0 feet, 722.5 feet NAVD88 
U.S. DEPARTMENT OF THE INTERIOR

U.S. GEOLOGICAL SURVEY

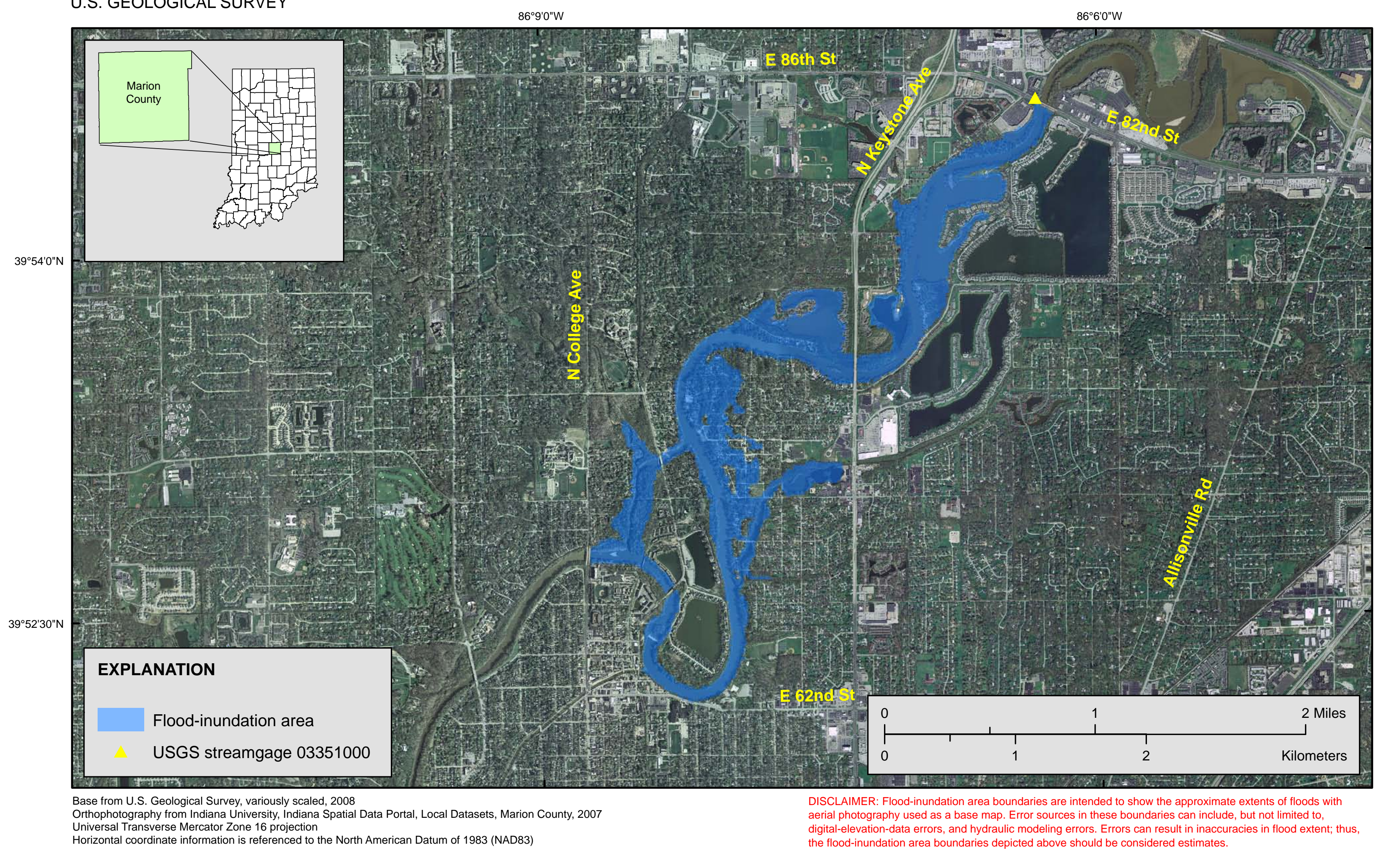

Flood-inundation areas for White River near Nora, Indiana (station 03351000), stage of 13.0 feet, 723.5 feet NAVD88. 
U.S. DEPARTMENT OF THE INTERIOR

U.S. GEOLOGICAL SURVEY

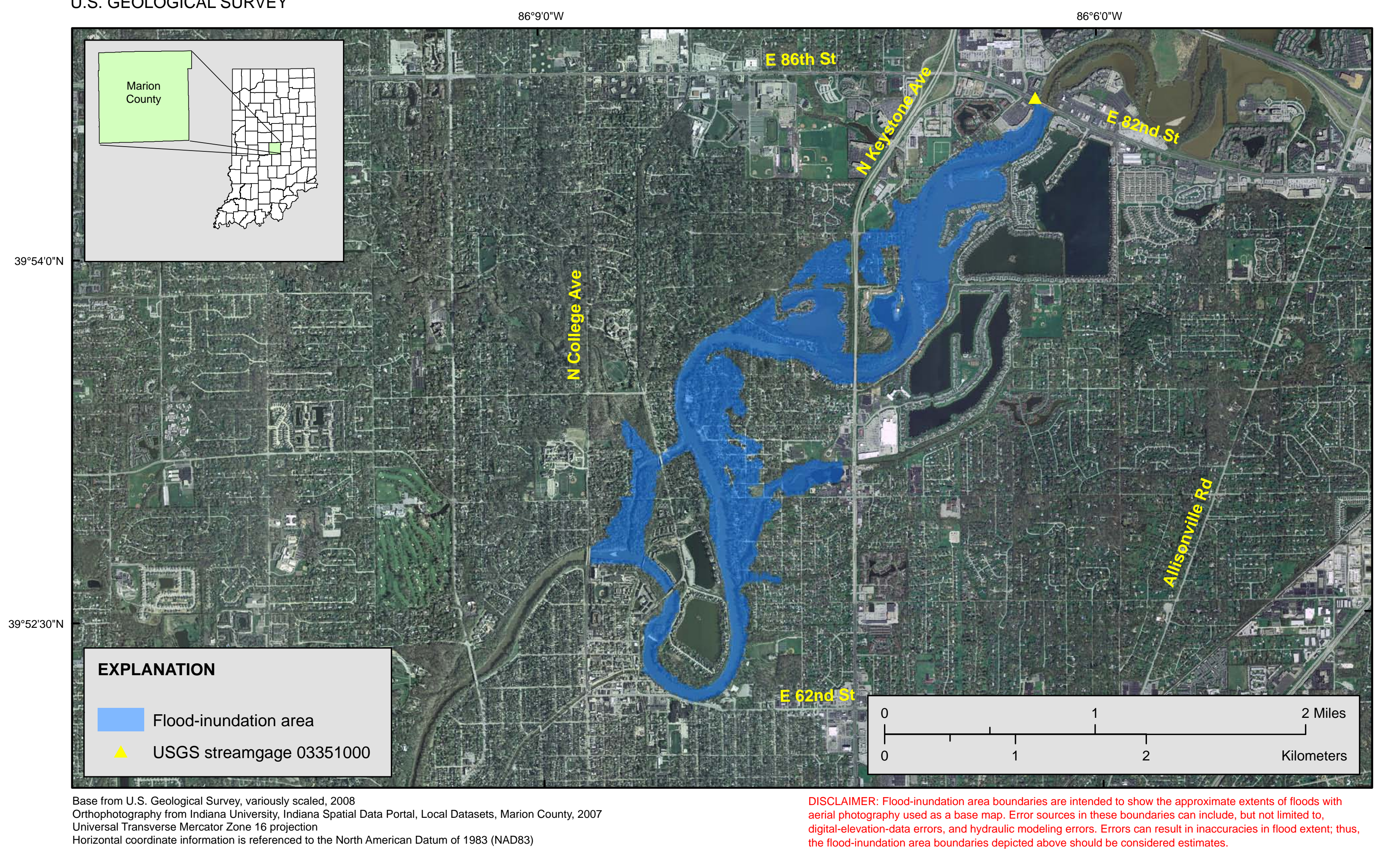

Flood-inundation areas for White River near Nora, Indiana (station 03351000), stage of 14.0 feet, 724.5 feet NAVD88. 
U.S. DEPARTMENT OF THE INTERIOR

U.S. GEOLOGICAL SURVEY

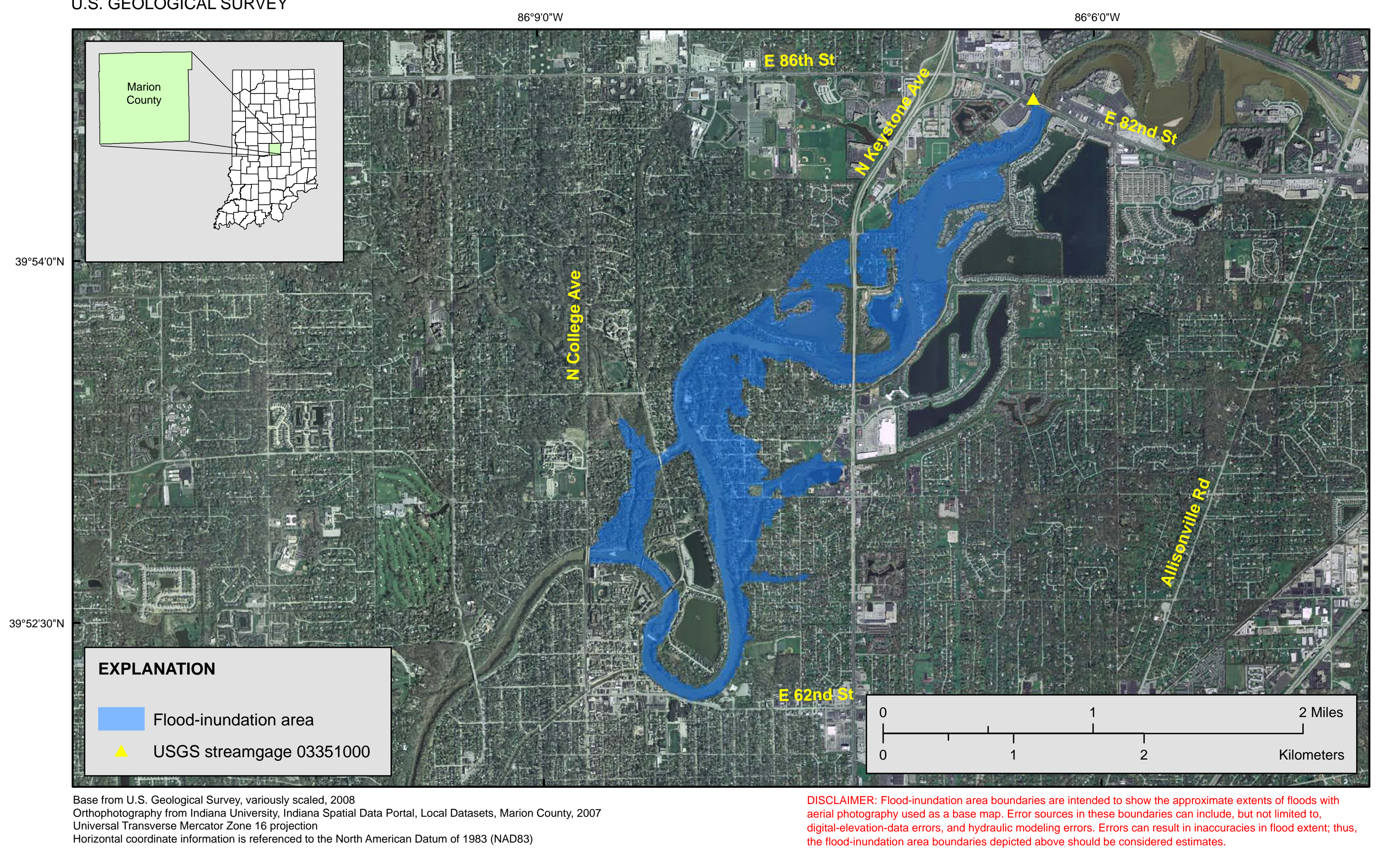

Flood-inundation areas for White River near Nora, Indiana (station 03351000), stage of 15.0 feet, 725.5 feet NAVD88. 
U.S. DEPARTMENT OF THE INTERIOR

U.S. GEOLOGICAL SURVEY

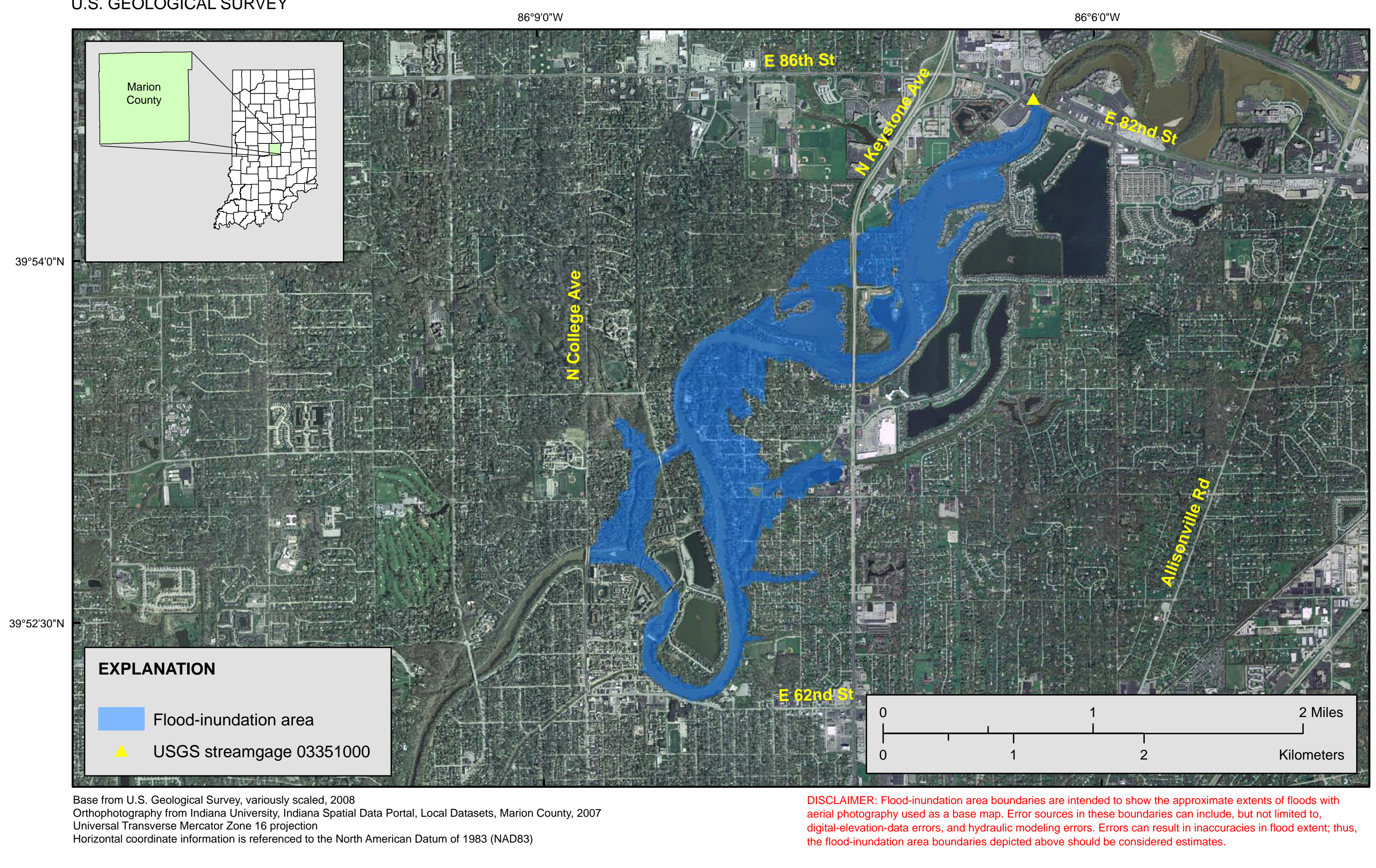

Flood-inundation areas for White River near Nora, Indiana (station 03351000), stage of 16.0 feet, 726.5 feet NAVD88. 
U.S. DEPARTMENT OF THE INTERIOR

U.S. GEOLOGICAL SURVEY

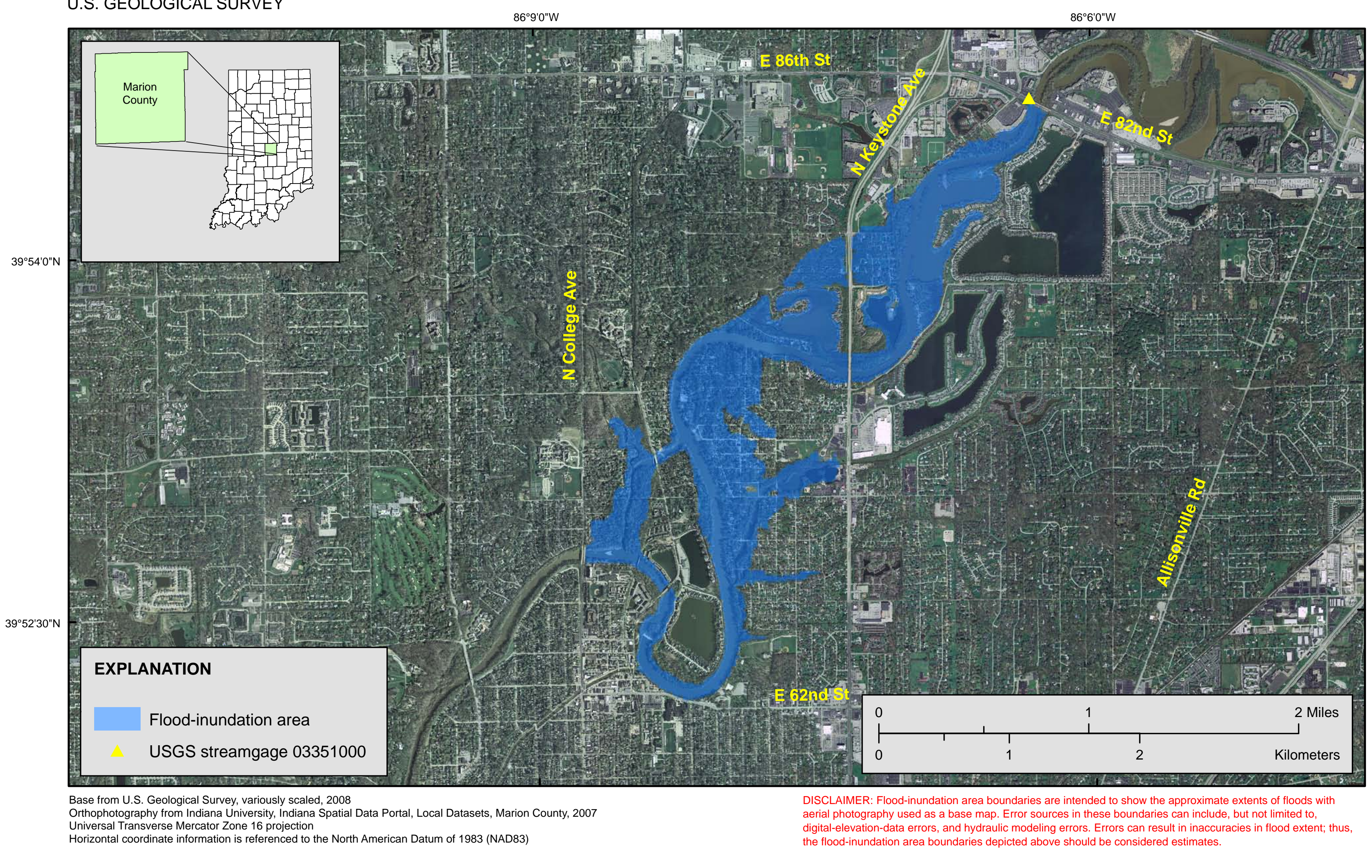

Flood-inundation areas for White River near Nora, Indiana (station 03351000), stage of 17.0 feet, 727.5 feet NAVD88 
U.S. DEPARTMENT OF THE INTERIOR

U.S. GEOLOGICAL SURVEY

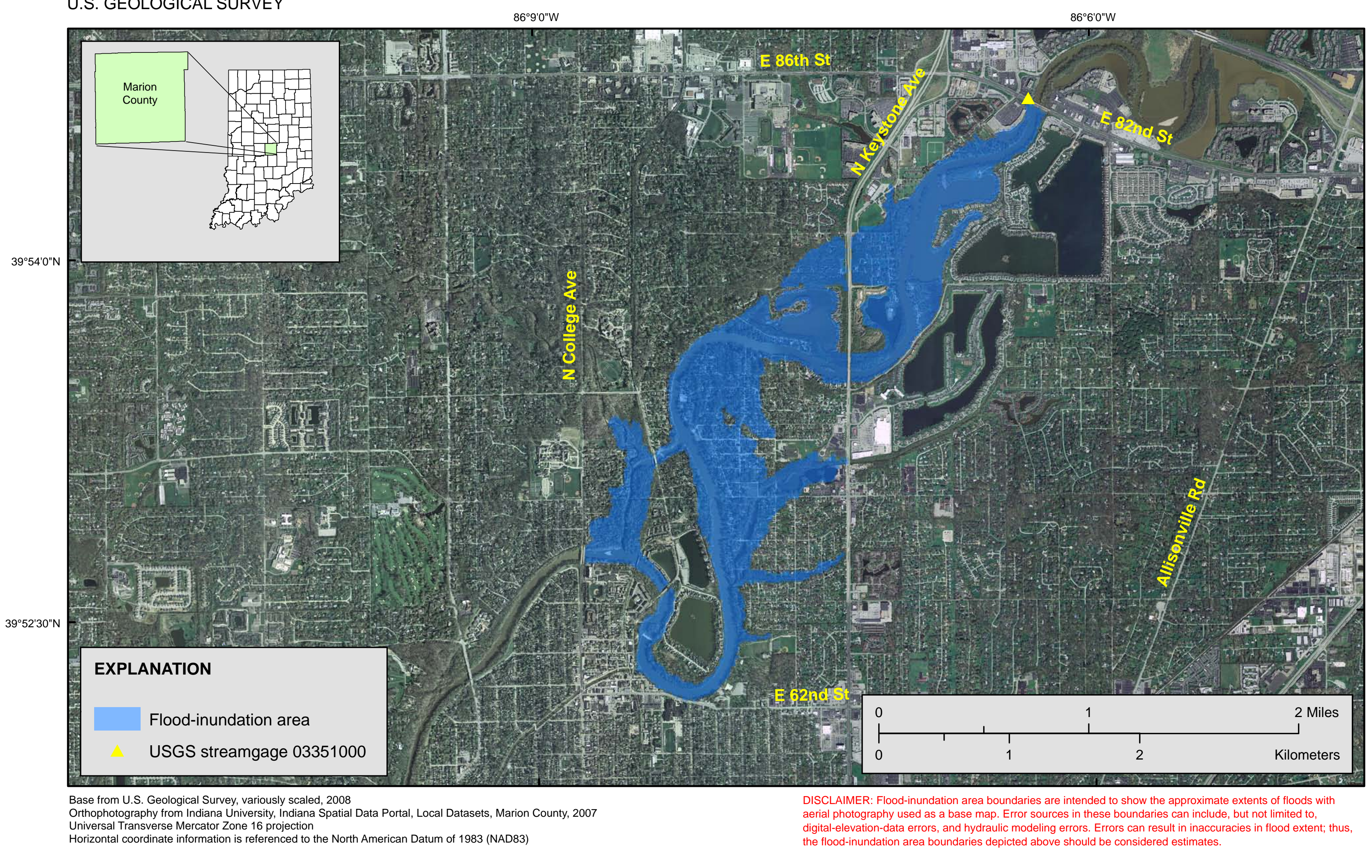

Flood-inundation areas for White River near Nora, Indiana (station 03351000), stage of 18.0 feet, 728.5 feet NAVD88. 
U.S. DEPARTMENT OF THE INTERIOR U.S. GEOLOGICAL SURVEY

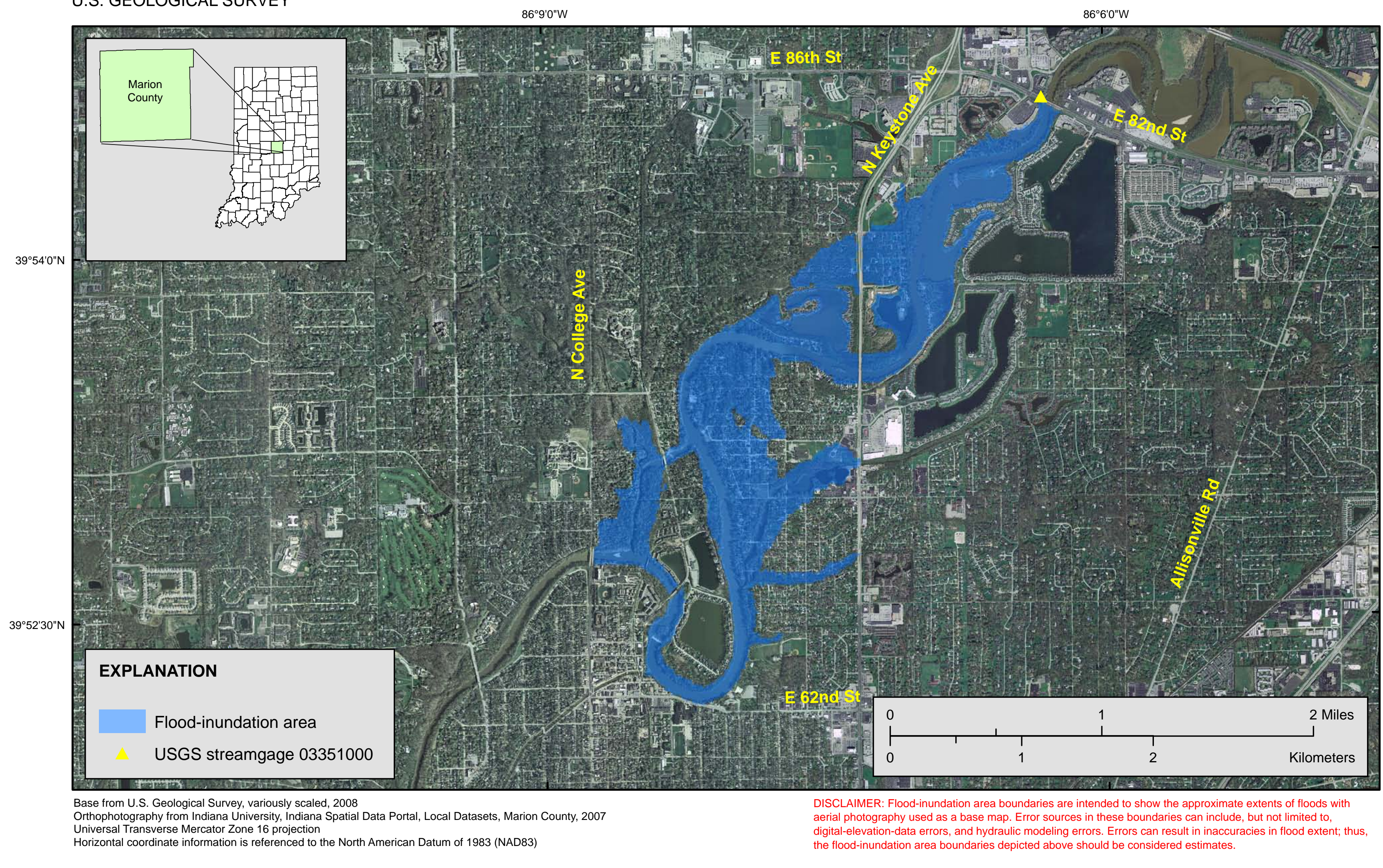

Flood-inundation areas for White River near Nora, Indiana (station 03351000), stage of 19.0 feet, 729.5 feet NAVD88 
U.S. DEPARTMENT OF THE INTERIOR

U.S. GEOLOGICAL SURVEY

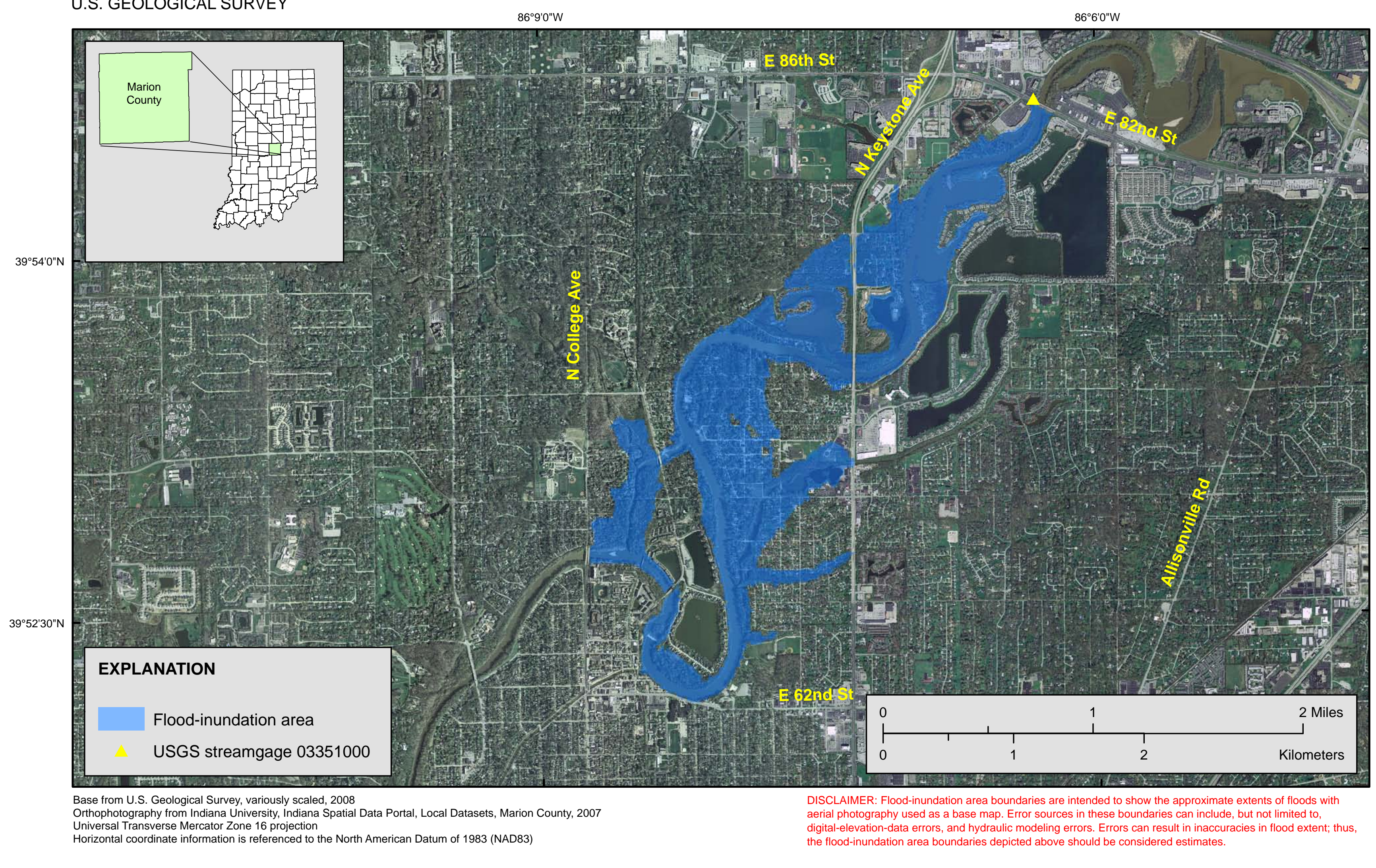

Flood-inundation areas for White River near Nora, Indiana (station 03351000), stage of 20.0 feet, 730.5 feet NAVD88. 
U.S. DEPARTMENT OF THE INTERIOR

U.S. GEOLOGICAL SURVEY

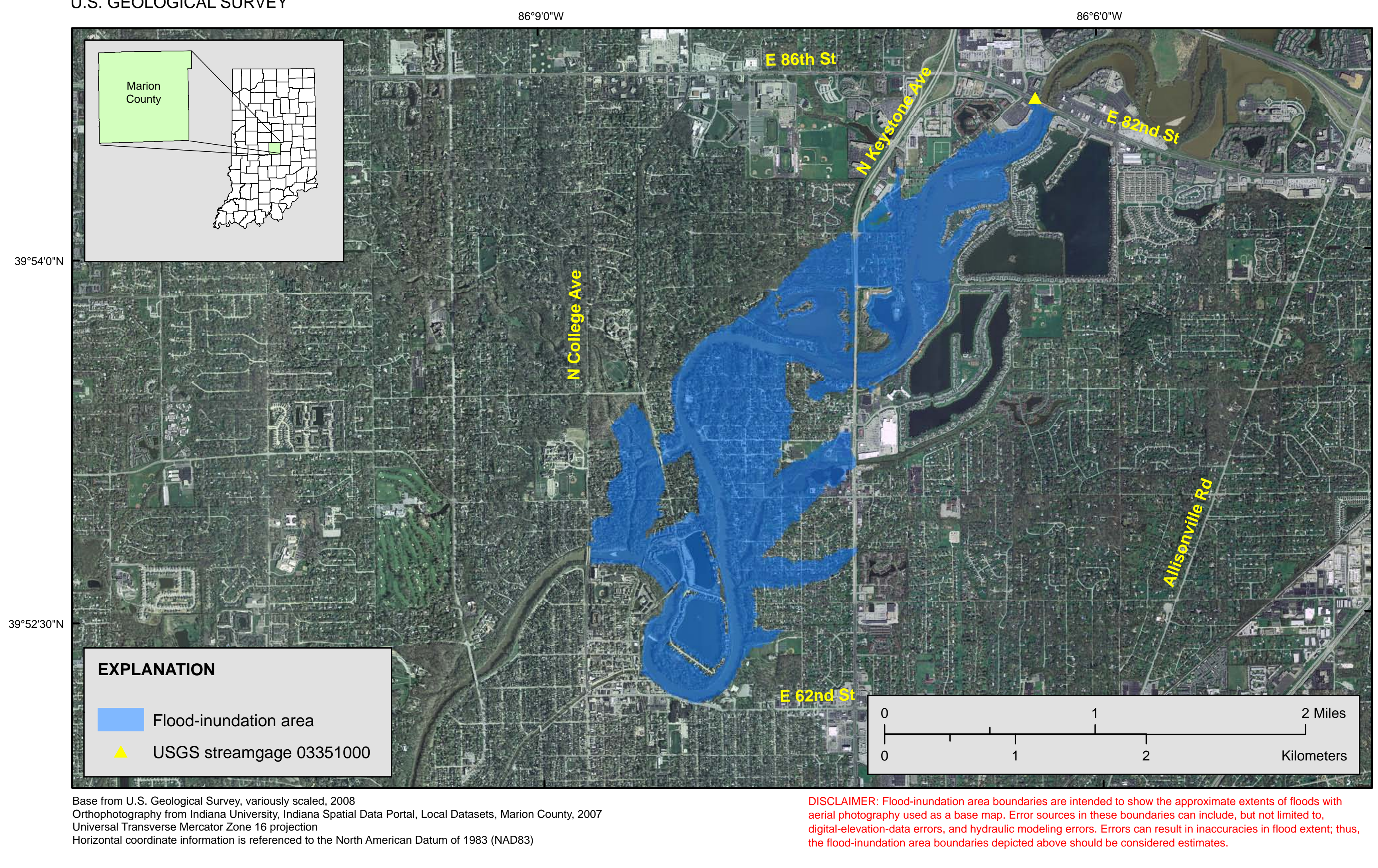

Flood-inundation areas for White River near Nora, Indiana (station 03351000), stage of 21.0 feet, 731.5 feet NAVD88. 
U.S. DEPARTMENT OF THE INTERIOR

U.S. GEOLOGICAL SURVEY

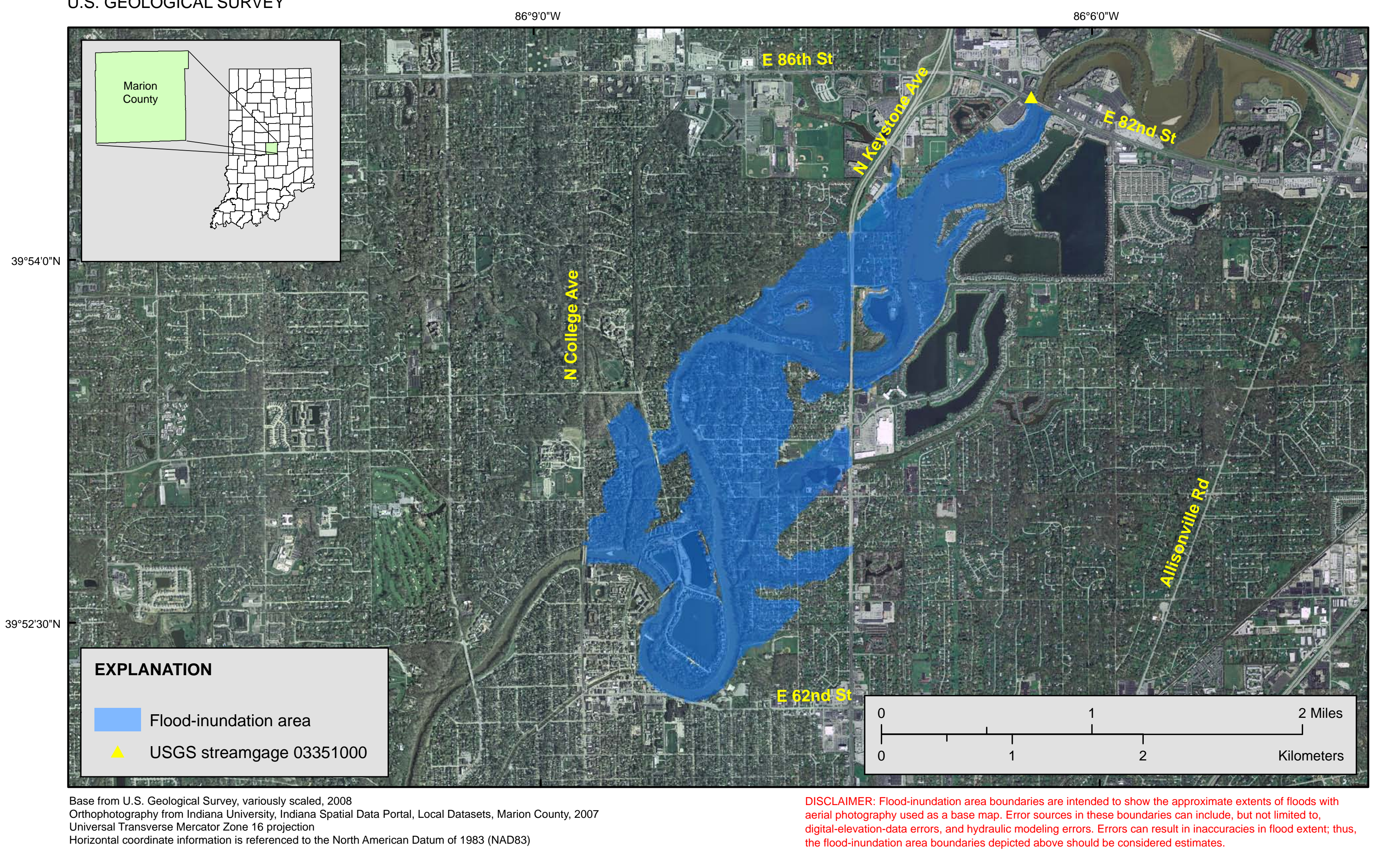

Flood-inundation areas for White River near Nora, Indiana (station 03351000), stage of 22.0 feet, 732.5 feet NAVD88. 


\section{Appendix 3. Examples of metadata for Geographic Information System (GIS) layers used to create maps in appendix 2}

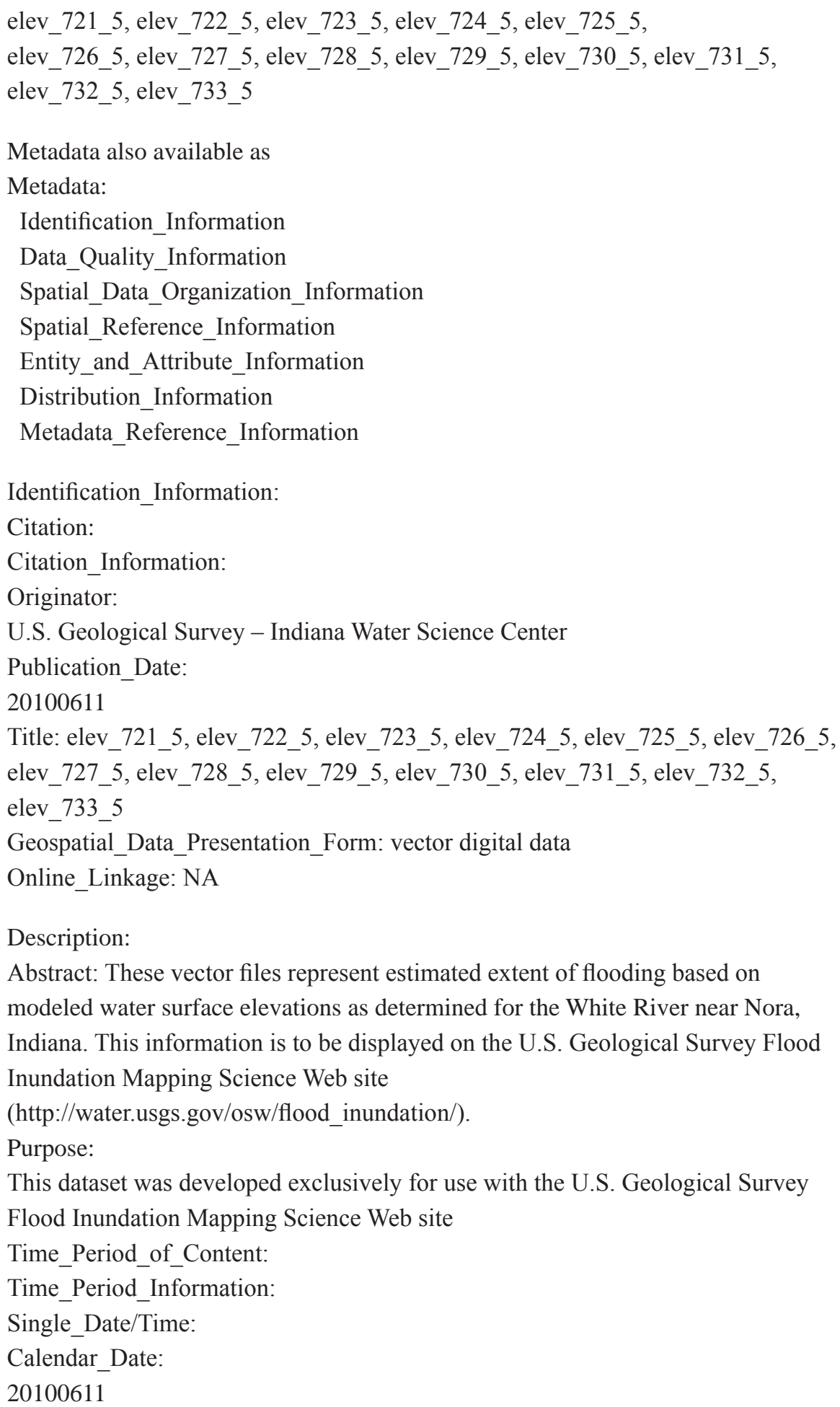


Currentness_Reference:

Ground condition

Status:

Progress: Preliminary

Maintenance_and_Update_Frequency:

The dataset will be maintained and updated as needed.

Spatial_Domain:

Bounding_Coordinates:

West_Bounding_Coordinate: -86.145711

East_Bounding_Coordinate: -86.103686

North_Bounding_Coordinate: 39.910501

South_Bounding_Coordinate: 39.869196

Keywords:

Theme:

Theme_Keyword_Thesaurus:

floods, White River, flood inundation mapping, hydrologic prediction, hydraulics

Theme_Keyword:

NA

Access_Constraints:

Use_Constraints:

Users must assume responsibility to determine the appropriate use of this data.

Users should be aware of the limitations of this dataset if using for critical

application.

Native_Data_Set_Environment:

Microsoft Windows XP Version 5.1 (Build 2600) Service Pack 3; ESRI ArcCatalog

9.3.0.1770

Data_Quality_Information:

Attribute Accuracy:

Attribute_Accuracy_Report: The attributes in this dataset are believed to be accurate.

Logical_Consistency_Report:

These data, although not tested, are believed to be logically consistent.

Geometry appears topologically clean.

Completeness_Report:

Spatial and attribute properties are believed to be complete, although attribute information has been simplified. Geometric thresholds from original data are preserved. No tests have been completed for exhaustiveness.

Positional_Accuracy:

Horizontal_Positional_Accuracy:

Horizontal_Positional_Accuracy_Report:

As with any engineering analysis of this type, variation from the estimated flood heights and flood-plain boundaries is possible. Details of the process used to produce these data can be found in project documentation available from the data contact person. Horizontal accuracy was tested by evaluating boundaries to best available topographic dataset.

Vertical_Positional_Accuracy: 
Vertical_Positional_Accuracy_Report:

As with any engineering analysis of this type, variation from the estimated

flood heights and flood-plain boundaries is possible. Details of the process used to produce these data can be found in project documentation available from the data contact person. Vertical accuracy was tested by evaluating boundaries to best available topographic dataset.

Lineage:

Source Information:

Source Citation:

Citation_Information:

Title:

elev_721_5, elev_722_5, elev_723_5, elev_724_5, elev_725_5, elev_726_5, elev_727_5, elev 728_5, elev_729_5, elev_730_5, elev_731_5, elev_732_5, elev_733_5

Larger_Work_Citation:

Citation Information:

Originator: U.S. Geological Survey - Indiana Water Science Center

Title:

elev_721_5, elev_722_5, elev_723_5, elev_724_5, elev_725_5, elev_726_5, elev 727 5, elev_728_5, elev $729 \_5$, elev_730_5, elev $731 \_5$, elev_732_5, elev 7335

Online Linkage: NA

Source_Scale_Denominator: U.S. Geological Survey - Indiana Water Science Center Type_of_Source_Media:

Source_Contribution:

The topographic data used for this work was obtained from existing digital elevation model contour datasets provided by the City of Indianapolis. The equivalent ground-elevation contour intervals of these data were 2 feet.

throughout the study area.

Process_Step:

Process Description:

USGS 2D hydraulic model (FaSTMECH) developed by the Geomorphology and Sediment Transport Laboratory was used to generate water-surface elevations at 1-foot intervals above the near bankfull stage at White River near Nora, Indiana. The model also outputs depth information at each of the model nodes. Both water-surface elevation and water-depth information are then converted to grid raster files with a cell size of 10 meters. Polygon vector files are then created from the grid raster files. The resulting polygons were edited to remove any flooding hydraulically disconnected from the main channel.

Process_Date: 20100611

Process_Time:

Source_Produced_Citation_Abbreviation:

Spatial Data Organization Information:

Direct Spatial Reference Method: Vector

Point and Vector Object Information:

SDTS Terms_Description:

SDTS_Point_and_Vector_Object_Type: G-polygon

Spatial_Reference_Information:

Horizontal_Coordinate_System_Definition:

Geographic:

Latitude_Resolution: 0.000000

Longitude Resolution: 0.000000

Geographic_Coordinate_Units: Decimal degrees 
Geodetic Model:

Horizontal_Datum_Name: North American Datum of 1983

Ellipsoid_Name: Geodetic Reference System 80

Semi-major_Axis: 6378137.000000

Denominator_of_Flattening_Ratio: 298.257222

Entity_and_Attribute_Information:

Detailed_Description:

Entity_Type:

Entity_Type_Label: "Name of the shapefile"

Attribute:

Attribute_Label: FID

Attribute_Definition: Internal feature number.

Attribute_Definition_Source: ESRI

Attribute_Domain_Values:

Unrepresentable_Domain:

Sequential unique whole numbers that are automatically generated.

Attribute:

Attribute_Label: Shape

Attribute_Definition: Feature geometry.

Attribute_Definition_Source: ESRI

Attribute_Domain_Values:

Unrepresentable_Domain: Coordinates defining the features.

Attribute:

Attribute_Label: AREA

Attribute:

Attribute_Label: PERIMETER

Attribute:

Attribute_Label: "Name of the shapefile"

Attribute:

Attribute_Label: TMPCOV_ID

Attribute:

Attribute_Label: GRID_CODE

Distribution_Information:

Resource_Description: Downloadable Data

Standard_Order_Process:

Digital_Form:

Digital_Transfer_Information:

Metadata_Reference_Information:

Metadata_Date: 20100611

Metadata_Contact:

Contact_Information:

Contact_Organization_Primary:

Contact_Organization:

U.S. Geological Survey - Indiana Water Science Center

Contact_Person: GIS Specialist

Contact_Address: 5957 Lakeside Blvd. 
Address_Type:

5957 Lakeside Blvd.

City: Indianapolis

State_or_Province: Indiana

Postal_Code: 46278

Contact_Voice_Telephone:

317-290-3333

Metadata_Standard_Name: FGDC Content Standards for Digital Geospatial Metadata Metadata_Standard_Version: FGDC-STD-001-1998

Metadata_Time_Convention: local time

Metadata Extensions:

Online Linkage: $<$ http://www.esri.com/metadata/esriprof80.html $>$

Profile_Name: ESRI Metadata Profile

Generated by mp version 2.9.6 on Mon Jun 14 15:33:10 2010 
elev_721_5, elev_722_5, elev_723_5, elev_724_5, elev_725_5, elev_726_5, elev_727_5, elev_728_5, elev_729_5, elev_730_5, elev_731_5, elev_732_5, elev_733_5

Metadata also available as

Metadata:

Identification_Information

Data_Quality_Information

Spatial_Data_Organization_Information

Spatial_Reference_Information

Distribution_Information

Metadata_Reference_Information

Identification_Information:

Citation:

Citation_Information:

Originator:

U.S. Geological Survey - Indiana Water Science Center

Publication_Date:

20100611

Title: elev_721_5, elev_722_5, elev_723_5, elev_724_5, elev_725_5, elev_726_5, elev_727_5, elev_728_5, elev_729_5, elev_730_5, elev_731_5, elev_732_5, elev_733_5

Geospatial_Data_Presentation_Form: raster digital data

Online Linkage: NA

Description:

Abstract:

These raster files represent estimated depth and extent of flooding based on modeled water-surface elevations as determined for the White River near Nora, Indiana. This information is to be displayed on the U.S. Geological Survey Flood Inundation Mapping Science Web site

(http://water.usgs.gov/osw/flood_inundation/).

Purpose:

This dataset was developed exclusively for use with the U.S. Geological Survey Flood Inundation Mapping Science Web site

(http://water.usgs.gov/osw/flood_inundation/).

Time_Period_of_Content:

Time_Period_Information:

Single_Date/Time:

Calendar_Date:

20100611

Currentness_Reference:

ground condition

Status:

Progress: Preliminary

Maintenance_and_Update_Frequency:

The dataset will be maintained and updated as needed.

Spatial_Domain:

Bounding_Coordinates:

West_Bounding_Coordinate: -86.146456

East_Bounding_Coordinate: -86.089828

North_Bounding_Coordinate: 39.914107

South_Bounding_Coordinate: 39.865243 
Keywords:

Theme:

Theme_Keyword_Thesaurus:

floods, White River, flood inundation mapping, hydrologic prediction, hydraulics

Theme_Keyword:

NA

Access Constraints:

Use_Constraints:

Users must assume responsibility to determine the appropriate use of this data.

Users should be aware of the limitations of this dataset if using for critical

application.

Native Data Set Environment:

Microsoft Windows XP Version 5.1 (Build 2600) Service Pack 3; ESRI ArcCatalog

9.3.0.1770

Data_Quality_Information:

Attribute_Accuracy:

Attribute_Accuracy_Report: The attributes in this dataset are believed to be accurate.

Logical_Consistency_Report:

These data, although not tested, are believed to be logically consistent.

Geometry appears topologically clean.

Completeness_Report:

Spatial and attribute properties are believed to be complete, although attribute information has been simplified. Geometric thresholds from original data are preserved. No tests have been completed for exhaustiveness.

Positional_Accuracy:

Horizontal_Positional_Accuracy:

Horizontal_Positional_Accuracy_Report:

As with any engineering analysis of this type, variation from the estimated

flood heights and flood-plain boundaries is possible. Details of the process used to produce these data can be found in project documentation available from the data contact person. Horizontal accuracy was tested by evaluating boundaries to best available topographic dataset.

Vertical_Positional_Accuracy:

Vertical_Positional_Accuracy_Report:

As with any engineering analysis of this type, variation from the estimated flood heights and flood-plain boundaries is possible. Details of the process used to produce these data can be found in project documentation available from the data contact person. Vertical accuracy was tested by evaluating boundaries to best available topographic dataset.

Lineage:

Source Information:

Source_Citation:

Citation_Information:

Title: 
elev_721_5, elev_722_5, elev_723_5, elev_724_5, elev_725_5, elev_726_5, elev_727_5, elev_728_5, elev_729_5, elev_730_5, elev_731_5, elev_732_5, elev_733_5

Larger_Work_Citation:

Citation_Information:

Originator: U.S. Geological Survey - Indiana Water Science Center

Title:

elev_721_5, elev_722_5, elev_723_5, elev_724_5, elev_725_5, elev_726_5,

elev_727_5, elev_728_5, elev_729_5, elev_730_5, elev_731_5, elev_732_5,

elev_733_5

Online_Linkage: NA

Source_Scale_Denominator: U.S. Geological Survey - Indiana Water Science Center

Type_of_Source_Media:

Source_Contribution:

The topographic data used for this work was obtained from existing digital elevation model contour datasets provided by the City of Indianapolis. The equivalent ground-elevation contour intervals of these data were two ft.

throughout the study area.

Process_Step:

Process_Description:

USGS 2D hydraulic model (FaSTMECH) developed by the Geomorphology and Sediment Transport Laboratory was used to generate water-surface elevations at 1-foot intervals above the near bankfull stage at White River near Nora, Indiana. The model also outputs depth information at each of the model nodes. Both water-surface elevation and water depth information are then converted to grid raster files with a cell size of 10 meters. Polygon vector files are then created from the grid raster files. The resulting polygons were edited to remove any flooding hydraulically disconnected from the main channel.

Process_Date: 20100611

Process_Time:

Source_Produced_Citation_Abbreviation:

Spatial_Data_Organization_Information:

Direct_Spatial_Reference_Method: Raster

Raster_Object_Information:

Raster_Object_Type: Grid Cell

Spatial_Reference_Information:

Horizontal_Coordinate_System_Definition:

Geographic:

Latitude_Resolution: 0.000000

Longitude_Resolution: 0.000000

Geographic_Coordinate_Units: Decimal degrees

Planar:

Planar_Coordinate_Information:

Planar_Coordinate_Encoding_Method: row and column

Coordinate_Representation:

Abscissa_Resolution: 0.000104 
Ordinate Resolution: 0.000104

Geodetic_Model:

Horizontal_Datum_Name: North American Datum of 1983

Ellipsoid_Name: Geodetic Reference System 80

Semi-major_Axis: 6378137.000000

Denominator_of_Flattening_Ratio: 298.257222

Distribution_Information:

Resource_Description: Downloadable Data

Standard_Order_Process:

Digital_Form:

Digital_Transfer_Information:

Metadata_Reference_Information:

Metadata_Date: 20100611

Metadata_Contact:

Contact_Information:

Contact_Organization_Primary:

Contact_Organization:

U.S. Geological Survey - Indiana Water Science Center

Contact_Person: GIS Specialist

Contact_Address: 5957 Lakeside Blvd.

Address_Type:

5957 Lakeside Blvd.

City: Indianapolis

State_or_Province: Indiana

Postal_Code: 46278

Contact_Voice_Telephone:

317-290-3333

Metadata_Standard_Name: FGDC Content Standards for Digital Geospatial Metadata

Metadata_Standard_Version: FGDC-STD-001-1998

Metadata_Time_Convention: local time

Metadata_Extensions:

Online_Linkage: $<$ http://www.esri.com/metadata/esriprof80.html $>$

Profile_Name: ESRI Metadata Profile

Generated by mp version 2.9.6 on Fri Jun 11 15:08:12 2010 


